\title{
THESIS
}

\section{ASPEN MORTALITY IN THE COLORADO AND SOUTHERN WYOMING ROCKY MOUNTAINS: EXTENT, SEVERITY, AND CAUSAL FACTORS}

\author{
Submitted by \\ Megan Dudley \\ Department of Bioagricultural Science and Pest Management
}

In partial fulfillment of the requirements

For the Degree of Master of Science

Colorado State University

Fort Collins, Colorado

Fall 2011

Master's Committee:

Advisor: William R. Jacobi

Jose Negron

Ned A. Tisserat

Patrick H. Martin 


\begin{abstract}
ASPEN MORTALITY IN THE COLORADO AND SOUTHERN WYOMING ROCKY MOUNTAINS: EXTENT, SEVERITY, AND CAUSAL FACTORS

Quaking aspen (Populus tremuloides Michx) is a deciduous hardwood tree widely distributed throughout North America. In Colorado, quaking aspen is found on a wide variety of sites, from the lower-elevation foothills of the eastern edge of the Rockies to moderate- and high- elevation montane sites throughout the Rocky Mountains. Aspen dieback has been documented throughout western North America over the past decade, resulting in stands that have either elevated proportions of overstory mortality or thin crowns, or both. Stands experiencing dieback may or may not produce regeneration cohorts. In this study, we surveyed aspen in the north-western corner of Colorado on the White River and Routt national forests, along the front range of Colorado on the Pike-San Isabel national forests, and in the south-central region of Wyoming on the Medicine Bow national forest during 2009 - 2010.

We established 573 random roadside survey plots in stands that contained at least $50 \%$ aspen cover type. From these random plots, we found average standing aspen tree mortality ranged from 3.3 to $23.7 \%$ on the four national forests and $11 \%$ on the east side of the continental divide and $4 \%$ on the west side. Low elevation stands had significantly less mortality (7\%) vs. high elevation $(8 \%)$. The roadside plot data suggests that Colorado's aspen on these four national forests overall were healthy; mortality rates
\end{abstract}


among aspen were fairly low $(\sim 3-8 \%)$ among all stems, and average percent live crown among adults was high $(\sim 85-90 \%)$, in spite of nearly ubiquitous presence of disease ( $97-99 \%)$ and high incidence of insect damage $(\sim 50-75 \%)$.

We also established 98 aspen stand assessment plots with half of the plots in damaged stands, as defined by U.S.D.A. Forest Service aerial detection surveys (ADS), and half in healthy aspen stands. Damaged stands were defined as those stands with (1) thinning crowns among at least $25 \%$ of adult aspen, (2) stands with moderate $(<50 \%$ of stems) levels of overstory mortality, or (3) stands with high ( $>50 \%$ of stems) levels of overstory mortality. Healthy aspen stands were defined as having (1) a maximum mortality rate of $5-7 \%$ among all aspen, and/or (2) more than $75 \%$ of adult aspen with full crowns.

Adult aspen in damaged stands tended to be less vigorous, based a health score index from 1 to 5, with higher scores indicating less healthy conditions (where $1=0-25 \%$ damage $; 2=25-50 \%$ damage; $3=>50 \%$ damage $; 4=$ recent dead $; 5=>5$ years dead). Health scores averaged 1.7 in healthy stands, compared to 2.3 in damaged stands. Saplings in damaged stands tended to be healthier with a score of 1.7 , compared to 2.2 in healthy stands. Further, there was no difference in the proportion live or total numbers of saplings per hectare between healthy and damaged stands. The prevalence of damaging organisms, such as Cytospora canker (20\% in damaged, $13 \%$ in healthy), wood-boring insects (27\% in damaged, $10 \%$ in healthy), and aspen bark beetles (16\% in damaged, $7 \%$ in healthy) was considerably greater among damaged stands. Site conditions also influenced the prevalence of some of these damage agents: bark beetles were most common among stands at low elevations (18\%, compared to $11 \%$ and $6 \%$ at moderate 
and high elevations, respectively); Cytospora canker was most common among stands on south- or west-facing aspects ( $20 \%$ and $19 \%$, respectively); both aspen bark beetles and Cytospora canker were also most common among stands in the southernmost section of the survey area, the Pike-San Isabel national forest (41\% and 36\%). There was no difference in the severity of canker or decay fungal infection between healthy and damaged stands. Cytospora canker infestations were more severe on the Medicine Bow NF compared to the other three national forests, and Marssonina foliar blight infection appeared to be most severe on slope summits, concave sites, and sites with either no to low percent slope or moderately steep slopes.

Based on the general state of aspen health within the study area, it appears that aspen in damaged stands were experiencing more severe environmental stress (e.g., late frost, drought, defoliation) and coupled with disease and insect infestations, resulted in greater mortality when compared to healthy stands. The severity of such conditions appears to be regional in scale, and it remains to be established that long-term or acute drought is the major factor influencing the observed conditions. Since no differences were detected in regeneration density between damaged or non damaged stands, it is possible that there will be no long-lasting effects on aspen longevity on these sites with the relatively low incidence of overstory mortality throughout all four national forests. 


\section{TABLE OF CONTENTS}

Chapter 1: Biology of Populus tremuloides Michx. and Associated Damage Agents ..1

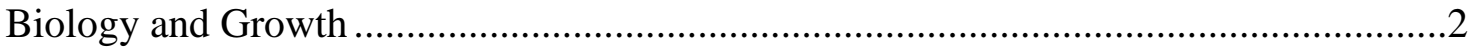

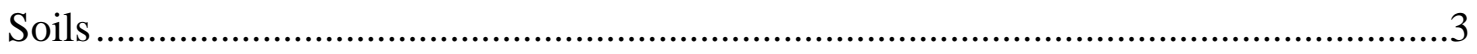

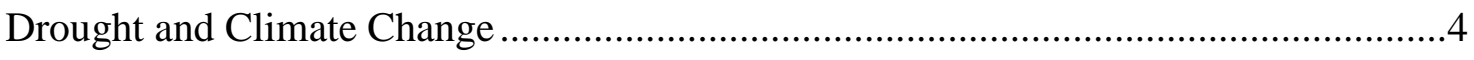

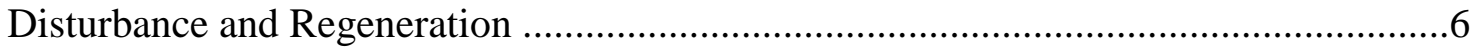

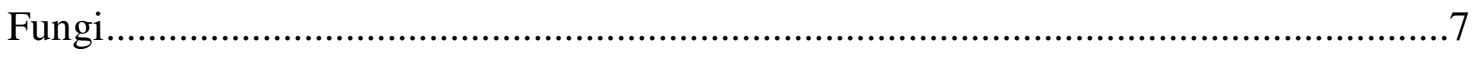

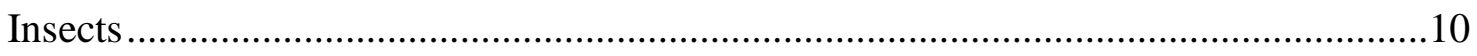

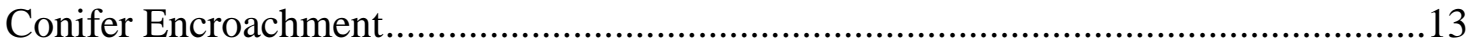

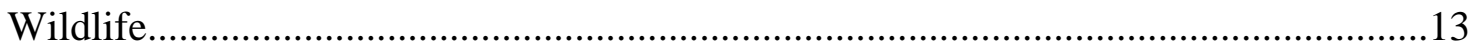

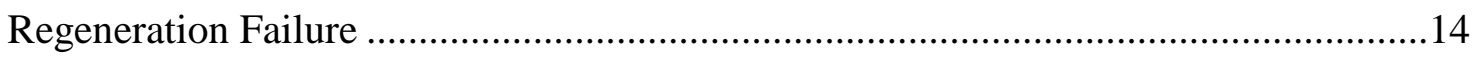

Aspen Dieback and Sudden Aspen Decline ............................................................15

Chapter 2: Aspen Health in Four National Forests in Colorado and southern

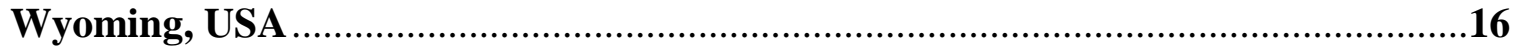

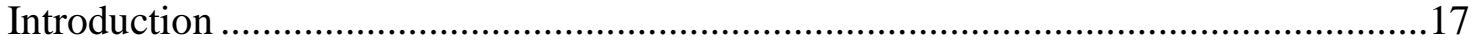

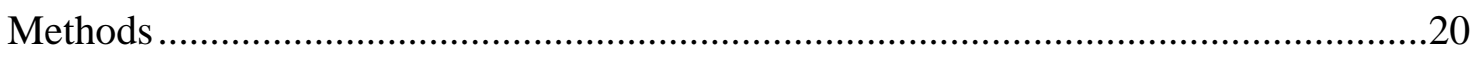

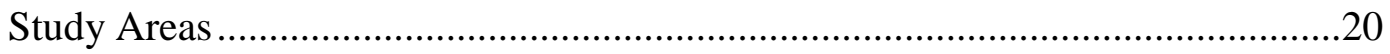

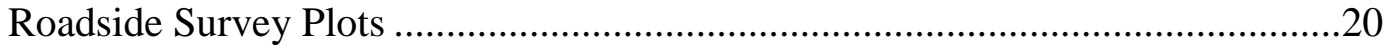

Aspen Stand Assessment Plots ................................................................ 21

Tree Cores and Cross-Sections ....................................................................26

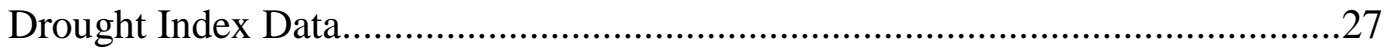

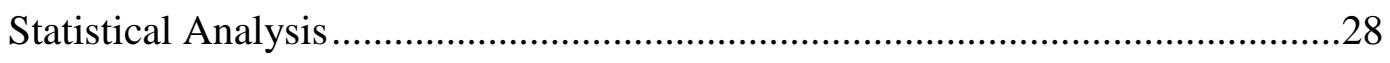

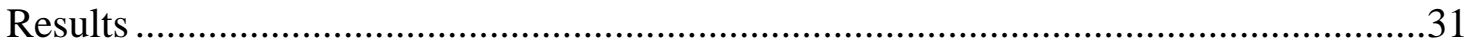

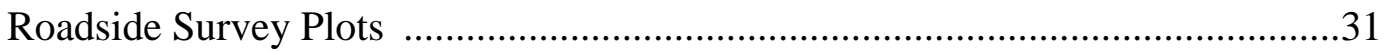

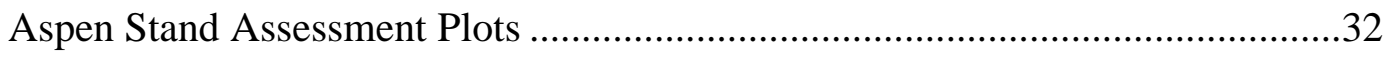

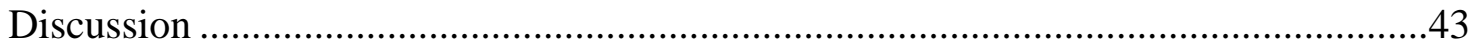

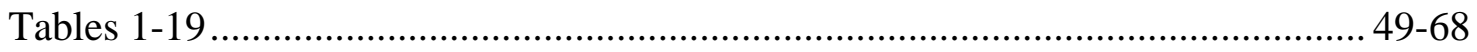




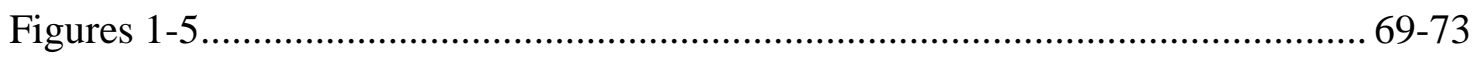

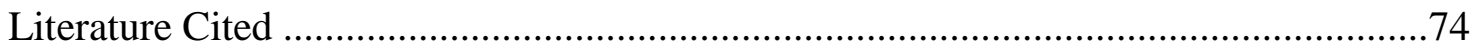

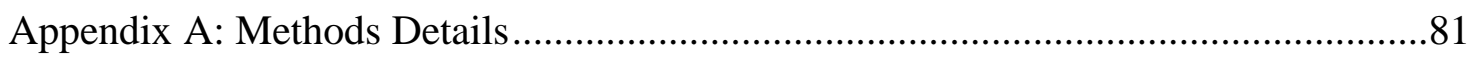

Appendix B: Analysis of Disease and Insect Prevalence by Aspen Size Class .............83 
Chapter 1: Biology of Populus tremuloides Michx. and Associated Damage Agents 


\section{Biology and Growth}

Populus tremuloides Michx. is a deciduous hardwood tree widely distributed throughout North America, with a broader geographic range than any other native tree species (Little, 1971). This tree assumes a clonal growth habit, and vegetative propagation is its primary method of reproduction. Root suckers originate from shoot meristems that occur within the cork cambium (Scheier, 1973). Apical dominance of the adult ramets is maintained by a steady flow of the plant hormone auxin, which is produced in the phyllosphere and transported to the roots (Eliasson, 1971). Removal, wounding, or death of the adult trees results in rapid declines in root auxin levels, which initiates suckering (Eliasson, 1971, 1972). Suckering is suppressed by the interaction between auxin and cytokinin, two phytohormones produced in the rhizosphere (Winton, 1968 and Wolter, 1969). Low ratios of cyokinins to auxins inhibit shoot initiation; high ratios promote shoot initiation (Winton, 1968 and Wolter, 1969). This species is dioecious, and both male and female flowers form as catkins (Jones, 1985).

Barnes (1966) determined that aspen seedlings may initiate suckering soon after establishment. The number of original seedlings (or 'ortets') in an aspen stand has been found to be inversely proportional to the clone size, regardless of site conditions (Barnes, 1966). Other differences, such as varied width: length ratio and serration patterns of leaves may vary with genotype (Barnes, 1975). Grant and Mitton (1979) observed major distributional differences between male and female aspen; female aspen dominated lower elevations (to 2,450 m) but were in the minority at high elevation sites (>2,900 $\mathrm{m}$ ). Female clones also appear to have a higher annual radial growth rate than males, regardless of elevation (Grant and Mitton, 1979). 
Genotype also appears to influence the levels of defensive foliar compounds, such as phenolic glycosides, and thus the susceptibility of the phenotype to defoliating insects (Donaldson and Lindroth, 2007). Similarly, recent work by Stevens and Esser (2009) indicates that there are gender differences in the amounts of two allelochemicals produced relative to growth. The production of condensed tannins, which are important protective compounds against phytopathogenic fungi and bacteria, appears to be more costly for female aspen than for males (Stevens and Esser, 2009). Phenolic glycosides, another major allelochemical, did not appear to be more costly to the females compared to the males (Stevens and Esser, 2009). Phenolic glycosides (PGs) are effective in deterring herbivory and defoliation by many foliage-feeding insects (Stevens and Esser, 2009). Overall, male and female aspen produce similar amounts of both defensive compounds (Stevens and Esser, 2009). A similar study by Smith, et al (2011), shows that phenolic glycoside concentrations are highest among young aspen, with the largest reduction in PGs occurring in young trees between ages 10 and 20 (Smith, E.A., et al, 2011). The same study showed that condensed tannin (CT) concentrations increase as trees age (Smith, E.A., et al, 2011).

Responses to drought tolerance (Griffin, et al, 1991), elevated ozone (Berrang, et al, 1991), and elevated carbon dioxide (Lindroth, et al, 2001), have all been shown to be phenotypically variable.

\section{Soils}

In Colorado, aspen grows in soils with a wide variety of textures (Jones, unpublished data). In Wisconsin, aspen grow best on sites with at least 3-4 feet of well 
drained topsoil (Fralish and Loucks, 1967). Saxton and Rawls (2006) determined that there is a strong relationship between the silt content in a particular soil and its waterholding capacity. However, Hancock, et al, (2008), showed that aspen grown in soils with a high sand and low clay content produce significantly more total biomass than do individuals grown in soils with high clay content.

Soil nutrient deficiency can have variety of impacts on aspen. For example, aspen tend to respond to nitrogen deficiency by producing smaller leaves, which results in a decrease in net photosynthesis (Greitner, et al, 1994). Burks (1994) theorizes that nitrogen deficiency may also increase the severity and incidence of cankers caused by Cytospora chrysosperma (Pers.:Fr.) Fr. Daubenmire (1953) found that aspen leaf litter contained higher levels of nitrogen, phosphorus, potassium, and calcium in comparison with a variety pine and fir species.

\section{Drought \& Climate Change}

\section{Acute Drought}

Studies indicate that, like most other tree species, growth rates of aspen are a function of climatic factors combined with various site and soil characteristics (Hogg, et al, 2008). The impacts of drought on P.tremuloides includes a decrease in leaf area index (LAI), which continues to be affected up to two years following the drought event (Krishnan et al, 2006). The same study determined that ecosystem respiration rates respond more quickly to drought onset, and are more sensitive to the end of a drought period than are ecosystem photosynthesis rates. This can be attributed to the fact that respiration rates are influenced by near-surface water content in soils, whereas 
photosynthesis rates are influenced by soil water content deeper in the rhizosphere (Krishnan, et al, 2006). In aspen, the severity of drought stress impacts the degree to which root water flow properties are altered (Siemens and Zwiazek, 2003). Severelystressed individuals display an inhibition of root hydraulic conductivity, as a result of an increase in the ratio of apoplastic to cell-to-cell water transport (Siemens and Zwiazek, 2003).

Drought also impacts the susceptibility of aspen to canker-causing fungi. A 1996 study showed that aspen inoculated with Cytospora chrysosperma (Pers.:Fr.) Fr. and exposed to drought conditions had significantly larger cankers one week after inoculation than did non drought-stressed trees (Guyon, et al, 1996). The same study also tested host susceptibility to Cytospora canker under waterlogging and defoliation conditions. Only trees that had been subjected to $75-100 \%$ defoliation showed increased canker size, relative to control trees (Guyon, et al, 1996).

\section{Climate Change \& Atmospheric Composition}

In their 2009 study, Rehfeldt, et al, utilized several different General Circulation (GCM) and emissions models to predict the range of 74 western U.S. forest species in 2030, 2060, and 2090. Based on these models, the authors predict a reduction in the current range of $P$. tremuloides by $6-41 \%$ by 2030 , and $46-95 \%$ by 2090 (Rehfeldt, et al, 2009). The authors also note that the future range of aspen is likely to occur on sites with elevations as much as 1000 meters higher than those found today (Rehfeldt, et al, 2009).

Changes in atmospheric composition are known to affect affect the health and growth rate of aspen. For example, tropospheric ozone, $\mathrm{O}_{3}$, has been shown to alter leaf 
surface characteristics in Populus tremuloides Michx., and increased concentrations of ground-level ozone may make trembling aspen more susceptible to fungal attack (Karnosky, et al, 2002). Like many other tree species, ozone accelerates maturation and foliage senescence in P. tremuloides (Greitner, et al, 1994).

Experiments featuring elevated carbon dioxide $\left(\mathrm{CO}_{2}\right)$ have indicated initial increases in relative growth rates (RGR) in aspen, although growth rates subsequently decrease, possibly due to limited plant available nutrients (Brown, K.R., 1991). Lindroth et al (2001) found that aspen genotype strongly influences how an individual responds to an atmosphere of enriched $\mathrm{CO}_{2}$. More specifically, researchers noted the differential response of aspen clones with respect to relative growth rates, including root: shoot ratio, and stem growth (Lindroth, et al, 2001). In an environment of enriched ozone and carbon dioxide, the initial positive influence of $\mathrm{CO}_{2}$ on growth did not completely offset the negative influence of tropospheric ozone on tree physiology (Percy et al, 2002).

\section{Disturbance \& Regeneration}

Aspen is known to regenerate prolifically following a stand-replacing fire (Scheier and Campbell, 1978). Fire intensity impacts sucker production; deeper parent roots tend to produce more suckers in areas where fire intensity was high, as compared to sucker production from shallower parent roots (Scheier and Campbell, 1978). Similarly, Perala (1995) found a 28\% decrease in productivity after parent roots were injured during high-intensity burns. However, studies by Kulakowski, et al (2006) and others have shown that severe fires on Colorado's western slope generally result in a temporary 'pulse' in aspen covertype. Therefore, some caution should be taken in generalizing fire 
effects on aspen over different ecosystems (Kulakowski, et al, 2006). It has been hypothesized that with the recent, massive die-off of Lodgepole pine (Pinus contorta Douglas ex. Louden) due to mountain pine beetle (Dendroctonus ponderosae Hopkins) infestation, will result in increased aspen covertype throughout the area. At this time, it is uncertain to what degree aspen will populate areas formerly occupied by lodgepole pine stands, though a recent study of post-outbreak forest structure within Rocky Mountain National Park indicates that there has been a slight increase in aspen covertype (Diskin, et al, 2011).

\section{Fungi}

A wide variety of necrotrophic and decay fungi attack aspen. These organisms range in pathogenicity; some, like Cytospora chrysosperma (Pers.:Fr.) Fr. (telemorphic form, Valsa sordid), are ubiquitous, existing as weak saprophytes on the bark surface, and cause damage only when the host is experiencing stressful environmental conditions (Sinclair, et al, 2005). When such favorable conditions do exist, Cytospora rapidly kills cambial tissue, effectively girdling and killing the host tree over several years (Bloomberg, W.J., 1962a; Bloomberg, W.J., 1962b). Others, such as sooty bark canker (Encoelia pruinosa), is an aggressive and lethal pathogen on aspen, which gains access to the phloem through small breaks in the cork cambium (Hinds and Ryan, 1985). Black canker (Ceratocystis fimbriata), is common throughout Colorado aspen stands (Worrall, et al, 2011; field observation, M. Dudley). This phytopathogenic fungus causes roughedged, target-shaped cankers on aspen as it kills newly-formed cambium while the host tree is dormant (Hinds, 1972b). Though not as common on aspen in the western United 
States, Hypoxylon mammatum (Wahl.) Mill. is a canker-producing fungus, which may significantly reduce yield in silvicultural settings (Enebak, et al, 1996). Cankers caused by this fungus spread rapidly among drought-stressed aspens (Bagga and Smalley, 1969). Finally, Cryptosphaeria lignyota forms narrow, elongated cankers on host trees, and is usually associated with large wounds to the cork cambium (Hinds, 1981).

Of the many decay fungi found on the bole of aspen, Phellinus tremulae (Bond.) Bond. and Borisov is a major cause of wood volume loss in Colorado aspen stands (Hinds and Wengert, 1977). This fungus causes a white rot of the heartwood and sapwood of the tree, but rarely spreads below the root crown (Ross, 1976a). Another decay fungus affecting the stem of aspen trees is Peniophora polygonia (Pers.), which enters through wounds or other openings in the cork cambium and develops into a yellowish, stringy (Etheridge, 1961). Decay fungi commonly found in the roots of quaking aspen include Flammulina velotipes, Ganoderma applanatum (Pers.) Pat., and Armillaria ostoyae (Vahl.: Fr) Kummer. F. velotipes is generally associated with basal wounds, and forms a white and brown mottled decay in the roots (Hinds and Wengert, 1977). Ganoderma applanatum (Pers.) Pat. also enters the host through wounds, and subsequently attacks many parts of the butt, including the sapwood, heartwood, and cambium (Ross, 1976a). This rot, which is whitish in appearance, eventually rots larger roots and may cause extensive windthrow (Ross, 1976b). Armillaria ostoyae (Vahl.: Fr) Kummer is found on a wide variety of forest trees, and has often been described as a saprophyte (Basham, 1958). However, Armillaria is also known to kill roots and decrease sprouting (Basham, 1958). Although this pathogen has long been considered a secondary pest, a 2003 study by Brandt, et al, found Armillaria to be a primary pathogen of aspen in 
the boreal forests of Canada. To date, there is little to no data on Armillaria occurrence on aspen in Colorado.

Numerous pathogenic fungi colonize the foliage of $P$. tremuloides. Among the most common is Marssonina populi (Lib.) Magnus, which causes black spot of aspen (Spiers, 1984). Affected foliage displays irregular brownish patches surrounded by a yellowish 'halo' (Spiers, 1984). Each brown patch often include up to several acervuli (Spiers, 1984). Ink spot of aspen is caused by two or more species of the fungus Ciborinia (Groves and Bowerman, 1955). Affected foliage turns brown, and black spots form (sclerotia) (Baranyay and Hiratsuka, 1967). The sclerotia may fall out of the leaf, leaving circular to ellipsoid- shaped holes (Baranyay and Hiratsuka, 1967). This disease tends to be more severe on smaller trees (Baranyay and Hiratsuka, 1967). Shepherd's Crook of aspen, caused by Venturia moreletii (anamorph Pollacia radiosa), causes a blight of leaves and twigs (Holeski, et al, 2009). Under wet conditions, this pathogen may kill many to all regenerating terminal shoots in an aspen stand (Sinclair and Lyon, 1987). Symptoms include small black spots on foliage, which enlarge and eventually kill the leaf as it spreads downward through the petiole (Sinclair and Lyon, 1987). As the fungus spreads further, the terminal shoot blackens and curls, forming the characteristic 'shepherd's crook' shape (Sinclair and Lyon, 1987). Leaf rust of aspen is caused by Melampsora medusae Thumen, a fungus which requires two hosts: a conifer (Douglas fir, Pseudotsuga menzesii (Mirb.) Franco) and aspen (Sinclair and Lyon, 1987). On aspen, this fungus is found as teliospores (found on the abaxial leaf surface as yellow spots) and urediospores (Ziller, 1974). Aspen are (usually) not seriously impacted by M. medusa, although studies conducted at the Free Air Carbon Enrichment (FACE) experimental site 
in Rhinelander, Wisconsin showed that hosts subjected increased tropospheric ozone levels have shown to be more susceptible to attack by M. medusa (Karnosky, et al, 2002).

\section{Insects}

Many insect species feed on the bole, stem, and twigs of aspen, including species in the orders Coleoptera and Lepidoptera. Commonly-found insects in aspen of the western U.S. include two bark beetles (Trypophloeus populi Hopkins and Procryphalus mucronatus (LeConte)), several borers (Agrilus liragus Barter \& Brown, Poecilonota cyanipes (Say), and Saperda calcarata (Say) among others), and an assortment of foliar insects, including leafminers, tiers, and rollers (Jones, Debyle, and Bowers, 1985; Jacobi, W.R., personal communication).

Both species of bark beetle that attack aspen prefer hosts which are dying or otherwise stressed (Petty, 1977). Trypophloeus populi Hopkins and burrows a small (2 cm in length) egg gallery just beneath the bark surface (Petty, 1977). One to one and a half generations are produced each year, and individuals overwinter in the larval stage (Petty, 1977). Invasions by this beetle are often followed by Procryphalus mucronatus (LeConte). However, unlike T. populi, P. mucronatus targets dead, softened and fermenting aspen bark (Furniss, 1987). The egg galleries formed by this species are narrower and placed deeper within the bark than those of T.populi. P. mucronatus is known to produce one and a half to two generations per year (Petty, 1977).

There is one species of Ambrosia beetle found on trembling aspen, Typodendron retusum, which is found throughout the western U.S. (Hinds and Davidson, 1972). The beetle, which is dark brown or black with a yellow stripe across each elytra, tunnels into 
the sapwood of the host tree to a depth of about $1 \mathrm{~cm}$ and then turns at a right angle to its point of entry and forms a tunnel around the entire circumference of the tree (Hinds and Davidson, 1972). This species attacks both healthy and dying trees, and creates patches of dead tissue on the host tree (Kuehnholz, et al, 2001).

Two species of wood borers, Agrilus liragus Barter \& Brown (the bronze poplar borer) and Saperda calcarata (Say) (the poplar borer) are commonly found on aspen. $A$. liragus is a Buprestid beetle native to North America and has been observed feeding on five species of Populus (Barter, 1965). The adults emerge in late spring and feed on aspen foliage (Barter, 1965). Females lay their eggs in small lots (5-8 eggs/ lot) in bark crevices (Barter, 1965). The larvae emerge about two weeks later and begin to bore into the cambium, and eventually bores a pupal cell in the outer xylem of the host tree before overwintering (Barter, 1965).

Similarly, Saperda calcarata (Say) is known to attack many species of Populus throughout North America (Broberg and Borden, 2005). S. calcarata appears to favor weakened hosts (Hanks, 1999). The females of this cerambycid lay their eggs in chewed furrows in aspen bark (Kukor and Martin, 1986). Larvae emerge and tunnel into the sapwood of the tree to feed (Kukor and Martin, 1986).

Of the many insects that feed on the foliage of $P$. tremuloides, the majority are of the order Lepidoptera, along with a few species of sawfly (order Hymenoptera) and leafhoppers (order Cicadellidae).

Choristoneura conflictana (Walker) is commonly known as the large aspen tortrix, and can be found feeding on aspen buds and leaves (Beckwith, 1973). Although it may cause branch death when populations are dense, it rarely kills its host (Beckwith, 
1973). Malacosoma disstria Hubner also feeds preferentially on aspen foliage, although it is found on other deciduous trees throughout the west besides quaking aspen (Furniss and Carolin, 1977). M. disstria overwinters as eggs, and the larvae emerge as aspen buds open in the spring (Stehr and Cook, 1968). Pupation occurs after 30-40 days, after which the moths mate and lay their eggs (Stelzer, 1968, 1971). Outbreaks of this insect are not uncommon, and may occur within the same aspen stand for several years in a row (Stelzer, 1968). Hogg, et al (2002), demonstrated that past annual defoliation events could be identified in tree cores by light-colored bands of growth resulting from the outbreak period. The larvae of Sciaphila duplex (Walsingham) (known as the aspen leaftier), feed on the inter-veinal tissues of aspen leaves (Furniss and Carolin, 1977). As they feed, the larvae roll up the skeletonized leaves and secure them (Furniss and Carolin, 1977). The aspen leaftier is capable of completely defoliating a tree over one season, and widespread in Canada, the Northern Rockies, Nevada, and California (McGregor, 1967). Alsophila pometaria (Harris) is one of several species of foliage-feeding geometrid moths, and is commonly known as the fall cankerworm (Furniss and Carolin, 1977). The cankerworm may be found feeding on the foliage of many deciduous shrub and tree species throughout the western U.S. (Furniss and Carolin, 1977).

Phyllocnistis populiella Chambers, also known as the aspen leafminer, forms a serpentine mine as it feeds on inter-cuticular leaf tissues (Davidson and Prentice, 1968). In general, this species does not cause severe damage to the host tree (Davidson and Prentice, 1968). The aspen blotchminer, Lithocolletis tremuloidiella Braun, like the aspen leafminer, also feeds on the inter-cuticular leaf tissues of aspen (Furniss and Carolin, 1977). The feeding patterns of these two species are quite different; while the leafminer 
forms a meandering mine, the blotchminer forms a rounded, irregularly-shaped patch in the leaf (Furniss and Carolin, 1977).

Three species of leafhoppers (Idiocerus sp.) are commonly found in Colorado, including I. formosus, I. lachrymalis, and I. suturalis (Graham, et al, 1963). These insects feed on juices from aspen leaves and other succulent tissues, and lay eggs in young twigs (Jones et al, in Debyle and Winokur, 1985). Finally, many species of common sawfly (Tenthredinidae) may be found feeding on aspen foliage (Graham, et al, 1963).

\section{Conifer Encroachment}

Aspen is the primary pioneer tree species in forest succession in forests throughout the Rocky Mountain region (Mueggler, 1985). Following a disturbance event (e.g., a stand-replacing fire), aspen colonize the area, either by seed or through sprouting from existing roots (Mueggler, 1985). Numerous studies have established that changes in fire regimes from the early twentieth century onward have clearly altered forest succession (Beaty, et al, 2008; Kaye, et al, 2003; Kurzel, et al, 2007), and favor coniferdominated landscapes, especially among current aspen/mixed conifer stands (Smith and Smith, 2005; Minnich, et al, 2000).

\section{Wildlife}

Aspen also serves as a food source for many ungulate and rodent species, including elk (Cervus canadensis Erxleben), moose (Alces alces), mice (Perognathus spp.), voles (Microtus spp.), and porcupines (Erethizon dorsatum (Linn.)). In areas of high elk densities, aspen may be heavily browsed (Kaye, et al, 2003). One study 
conducted in Colorado's Rocky Mountain National Park indicated that over $70 \%$ of the Park's aspen stands showed evidence of elk browsing, particularly in areas identified as elk winter range (Kaye, et al, 2003). Similarly, a study by Romme, et al (1995) in Yellowstone National Park found that elk browsed aspen indiscriminately of age class; unbrowsed stems apparently escaped unscathed due to snow cover (Romme, et al, 1995).

\section{Regeneration Failure}

A variety of biotic and abiotic factors may contribute to the failure of an aspen stand to produce regeneration (i.e., 'suckers'). Jacobi, et al (1998), found two scenarios under which aspen regeneration failure could occur on the western slope of Colorado. Under very wet spring conditions, waterlogging predisposes trees to infection by cankercausing fungi (Jacobi, et al, 1998). Aspen exposed to drought conditions were likewise predisposed to phytopathogenic fungi (Jacobi, et al, 1998). In areas where elk (Cervus canadensis) densities are high, regeneration may be decreased due to winter browsing (Suzuki, et al, 1999). Similarly, MacIsaac, et al (2006) determined that regeneration gaps in post-harvest aspen stands were attributable to grazing (by moose, Alces alces) and heavy herbaceous vegetation cover. The effect of vegetation cover may suppress regeneration in two ways: by increasing competition for available growing space and soil moisture; by lowering soil temperatures beneath heavily-vegetated areas, which in turn may prevent auxin levels in underlying aspen roots to be altered, and thus fail to initiate suckering (MacIsaac, et al, 2006). This is supported by the findings of Lavertu, et al, (1994), who showed that litter removal enhanced regeneration production in aspen stands 
in northwestern Quebec. Late spring frost may also suppress regeneration (Wolken, et al, 2009).

\section{Aspen Dieback and Sudden Aspen Decline}

Aspen dieback has occurred throughout western North America over the past decade. Forest health researchers have documented stand damage in southern Utah (Bartos, 2008), Arizona (Fairweather, et al, 2008), and the boreal aspen forests of Alberta and Saskatchewan (Hogg, et al, 2008). Worrall, et al (2008) first observed this phenomenon in Colorado during 2005, and coined the term 'Sudden Aspen Decline' (SAD), based on their observation that affected stands underwent rapid mortality (Worrall, et al, 2008). Among affected stands, mortality increased from an average of $10 \%$ to between $280-567 \%$ (Worrall, et al, 2008). Stands experiencing significant mortality rates also lacked a regeneration cohort, suggesting that they may not persist on the landscape (Worrall, et al, 2008). There were three hypothetical effects that were suggested that may be acting synergistically to speed the rates of aspen damage. These include: drought conditions; stand aspect and elevation, and clone susceptibility to disease and damage agents (Worrall, et al, 2008; Bartos, 2008; Hogg, et al, 2008; Fairweather, et al, 2008). Biological agents that may be affecting survivorship of stands include Cytospora canker, the poplar borer, the bronze poplar borer, and two aspen bark beetle species (Worrall, et al, 2008). Though these agents are generally considered to be of secondary importance to stand health, stands which are already stressed may experience increased mortality from these disease and damage agents (Worrall, et al, 2008, 2010). 
Chapter 2: Aspen Health in Four National Forests in Colorado and southern Wyoming, USA 


\section{Introduction}

Populus tremuloides Michx. is a deciduous hardwood tree widely distributed throughout North America, with a broader geographic range than any other native tree species across the continent (Little, 1971). In Colorado, aspen covers approximately 1.2 million hectares, and is one of the few hardwood tree species in the state.

This tree assumes a clonal growth habit, and vegetative propagation is its primary method of reproduction. Aspen is an important successional tree species throughout the forests of the Rocky Mountains and the western United States and Canada (Mueggler, 1985). Root suckers originate from shoot meristems that occur within the cork cambium (Scheier, 1973). Apical dominance of the adult stems, 'ramets', is maintained by a steady flow of the plant hormone auxin, which is produced in the phyllosphere and transported to the roots (Eliasson, 1971). Removal, wounding, or death of the adult trees results in rapid declines in root auxin levels, which initiates suckering (Eliasson, 1971, 1972; Sandberg, 1951). Aspen clone size has been shown to be inversely proportional to the number of original seedlings (or 'ortets'), regardless of site conditions (Barnes, 1966). Other clonal differences, such as varied width: length ratio and serration patterns of leaves vary with genotype (Barnes, 1975). Genotype also appears to influence the levels of defensive foliar compounds, such as phenolic glycosides, and thus the susceptibility of the phenotype to defoliating insects (Donaldson and Lindroth, 2007).

Studies indicate that, like most other tree species, growth rates of aspen are a function of climatic factors combined with various site and soil characteristics (Hogg, et al, 2008). The impacts of drought on aspen includes a decrease in leaf area index (LAI), which continues to be affected up to two years following the drought event (Krishnan et al, 2006). The same study suggested that ecosystem respiration rates respond more 
quickly to drought onset, and are more sensitive to the end of a drought period than are ecosystem photosynthesis rates. In aspen, the severity of drought stress impacts the degree to which root water flow properties are altered (Siemens and Zwiazek, 2003).

Widespread aspen dieback has been observed throughout western North America over the past decade (Bartos, 2008; Hogg, et al, 2008) Forest health researchers have documented stand mortality in southern Utah (Bartos, 2008), Arizona (Fairweather, et al, 2008), and the boreal aspen forests of Alberta and Saskatchewan (Hogg, et al, 2008). Worrall, et al (2008) first coined the term 'Sudden Aspen Decline' (SAD), in Colorado during 2005. SAD is distinguishable from aspen dieback based on the rapid rate of stand death with SAD; affected stands experience dramatic increases in overstory mortality and lack a regeneration cohort (Worrall, et al, 2008).

Several factors are hypothesized to be acting synergistically to increase the occurrence of aspen dieback and mortality. These include: drought conditions; stand aspect and elevation, and clone susceptibility to disease and damage agents (Worrall, et al, 2008; Bartos, 2008; Hogg, et al, 2008; Fairweather, et al, 2008). Biological agents that may affect survivorship of stands include Cytospora canker (Cytospora spp), poplar borer (Saperda calcarata), the bronze poplar borer (Agrilus liragus), and two aspen bark beetle species (Trypophloeus populi and Procryphalus mucronatus) (Worrall, et al, 2008;

Jacobi, W.R., personal communication). Though these agents are generally considered to be of secondary importance to stand health (primary disease and damage agents include sooty bark (Encoelia pruinosa) and Cryptosphaeria (Cryptosphaeria lignyota) cankers and forest tent caterpillar (Melacosoma disstria), stands which are already stressed may experience increased mortality from these disease and damage agents (Worrall, et al, 
2008, 2010). The area where Sudden Aspen Decline has been documented includes the national forests of southwestern Colorado (i.e., the Gunnison, Grand Mesa, and Uncompahgre National Forests). The U.S. Forest Service Forest Health Management group has conducted aerial surveys of aspen damage on national forests in Colorado and southern Wyoming since 2006. Thus, prior to this study, it was not known whether the mortality observed among aspen stands throughout the areas beyond the extent of the SAD study area was attributable to Sudden Aspen Decline, or to some other factor.

The overall objectives for this project were two-fold: to determine the overall health of aspen stands on U.S.D.A. Forest Service lands in Colorado and southern Wyoming. We achieved this through the establishment of random rapid roadside survey plots and a field assessment of damaged and healthy aspen stands on U.S.D.A. Forest Service lands in Colorado and southern Wyoming, based on the Forest Service's aerial survey data to determine the causes of damage. The specific hypotheses for the overall health survey were: that basal area and stand density would be similar in all forests sampled east and west of the Continental Divide; that aspen stand structure would be similar in all national forests sampled; the proportion of aspen dieback would be uniform among sampled forests, and is not related to site and stand factors. For the field survey (i.e., determining the cause of aspen dieback), our specific hypotheses were as follows: the observed aspen dieback was not related to site or stand characteristics; incidence of diseases or insects among aspen was not related to any one site, stand or abiotic factor; aspen dieback was not related to damage incurred by a particular disease or insect. 


\section{Methods}

\section{Study Areas:}

Four study areas were used to assess aspen stands for health and to determine the causes of aspen mortality. Two of the study areas (Pike-San Isabel and Medicine Bow National Forests) were east of the Continental Divide and two were located west of the Divide (White River and Routt National forests). The four study areas represent the drier, aspen stands that occur along the eastern slopes of the Colorado Front Range of the Rocky Mountains and the wetter, western slope areas. Sampling areas were selected because they had the most aspen area, based on a remotely-sensed vegetation data layer (downloaded from the Colorado Vegetation Classification Project website, http://ndis.nrel.colostate.edu/coveg/) in a Geographic Information System (GIS) (Tables 21 and 22). Aspen stands in two or three districts per forest were sampled.

\section{Roadside Survey Plots}

During 2009-2010, we installed 573 survey plots along roads in eleven ranger districts on the four national forests (Table 1). GIS was used to show areas where aspen stands and forest roads intersected, and survey points were generated using the 'Create Random Points' tool in ArcToolbox ${ }^{\circledR}$ (ESRI, Redlands, CA, USA). One survey point was generated for each potential roadside survey plot. Potential survey points were loaded onto GPS units (Garmin Etrex Legend H). We utilized the survey points to begin a survey; subsequent roadside plots were placed $160 \mathrm{~m}$ (0.10 miles) apart from each other. In areas where the aspen vegetation type was extensive, we increased plot spacing to 804 m (0.5 miles). 
Site and Tree Data

Rectangular roadside plots $(25$ x $5 \mathrm{~m}, 0.0125 \mathrm{ha})$ were placed 10 - $50 \mathrm{~m}$ from the road edge, and contained at least $50 \%$ aspen, based on visual estimation. Data recorded included: location via GPS (Garmin Etrex Legend H), elevation (from GPS or topographical map), aspect (degrees), percent slope, slope position (e.g., summit, shoulder slope, backslope, footslope, toeslope, or valley bottom), slope configuration (e.g., concave, convex, broken, undulating or linear), a visual estimation of percent stand mortality and percent crown dieback, presence or absence of regeneration (i.e., those trees with $\mathrm{DBH}<12 \mathrm{~cm}$ ), the stand structure (i.e., open or closed canopy, with single or multiple cohorts), understory and shrub species, other tree species, presence of obvious insect or disease damage, and presence of other damage agents (such as ungulate bark browsing, human-caused damage, etc). Percent stand mortality was the estimated overall mortality of the stand, including saplings, poles, and adult-sized aspen.

\section{Aspen Stand Assessment Plots}

Plot Selection

We randomly selected damaged and healthy aspen stands to assess stand health based on aerial survey information. The U.S. Forest Service conducts yearly aerial surveys of forest pests in Colorado and southern Wyoming. To do so, aerial survey technicians observe affected stands from fixed-wing aircraft, and digitize polygons onto georeferenced maps displayed on a laptop computer

(https://fs.usda.gov/Internet/FSE_DOCUMENTS/fsbdev3 038662.pdf). In 2006, the 
Forest Service began to survey aspen stands across Colorado, due to reports of aspen mortality on many national forests. Four categories of affected stands were mapped: (1) aspen stands currently undergoing an apparent defoliation or foliage discoloration event (though not to the extent to be labeled as aspen mortality and dieback); (2) stands with thinning crowns among at least $25 \%$ of adult aspen; (3) stands with moderate ( $<50 \%$ of stems) levels of overstory mortality; or (4) stands with high (>50\% of stems) levels of overstory mortality (Howell, unpublished methods).

Approximately half of our survey plots were established in aspen stands classified as 'damaged' (categories 2-4 in the 2008 and 2009 aerial surveys) and half in unaffected stands (though not as a paired-plot design). For a stand to be designated as 'damaged', it must have been mapped by aerial surveyors as showing significant mortality, (i.e., the moderate to heavy or light to moderate mortality categories listed above), widespread defoliation, or significant crown thinning (as described above). Prior to conducting field work, GIS software (ArcMap® 9.2, ESRI) was used to create a set of random points within the damaged and unaffected aspen cover types. The aspen damage datasets were obtained from the U.S. Forest Service's Region 2 Aerial Sketchmapping website (http://www.fs.usda.gov/wps/portal/fsinternet/). An aspen vegetation covertype was utilized to place survey plots in healthy aspen stands. The vegetation dataset was produced by the Colorado Vegetation Classification Project (CVCP) (http://ndis.nrel.colostate.edu/coveg/). This state-wide vegetation type map is based on data from the Landsat Thematic Mapper TM satellite. Data from CVCP were downloaded by watershed, and areas containing at least 50\% aspen coverage were selected from the larger dataset. Individual watershed-area shapefiles of aspen covertype were then 
compiled into one large shapefile using the 'Union' tool in the 'Overlay' toolset in ArcToolbox (ESRI, 2008). Total area of aspen covertype and yearly mapped damage areas within each of the national forests and ranger districts surveyed can be found in Tables $18 \& 19$.

The set of randomized points (generated using the 'Create Random Points' tool within the Data Management toolset in ArcToolbox) were uploaded onto a GPS unit (Garmin Etrex Legend $H ®$ ). However, we encountered significant difficulties locating these stands in this way, due to either surveyor error, or incorrect identification of vegetation type, so we utilized orienteering skills to correctly identify the randomly selected stand. Potential stands had to be at least $50 \%$ aspen stems, and be at least $120 \mathrm{x}$ $20 \mathrm{~m}$ in size, or another potential site was located.

\section{Transect Data}

In order to gain a general overview of site and stand conditions, a transect of not more than 100 meters was established, in a direction which bisected the aspen stand. Stand-level data collected included: transect bearing; percent slope; aspect (degrees); elevation (meters); slope position (e.g., summit, shoulder slope, backslope, footslope, toeslope, or valley bottom); slope configuration (e.g., linear, undulating, broken, convex, or concave); evidence of disturbance (e.g., fire scar, evidence of grazing, thinning, avalanche, or other major disturbance event); stand structure (e.g., an open or closed stand, with one or more stories); tree species (other than aspen) present, and the dominant shrub and herb species present. These data were obtained during transect establishment. 
The presence of Armillaria root disease on aspen was determined by sampling three recently dead or dying trees randomly located along each transect for the presence of mycelial fans. We utilized methods developed by Blodgett, Allen and Burns, 2007 (INT-EM-07-01). We excavated a 12-cm deep trench around the base of the tree, starting at the tree's northern-facing aspect. Bark was removed, and the roots and root crown were examined for mycelial fans and rhizomorphs. If mycelium was found on the first or second tree examined, we stopped searching for Armillaria sign on dead trees, and examined up to two living trees with thin crowns or small, yellowing leaves for presence of mycelium.

\section{Plot Data}

Three circular, fixed-area subplots with an area of $200 \mathrm{~m}^{2}$ and a radius of $8 \mathrm{~m}$ were randomly established along the $100 \mathrm{~m}$ transect (Fig. 1). Within each of the three subplots, adult trees $(\mathrm{DBH}>12 \mathrm{~cm})$ were tallied, and diameter recorded at breast height (1.37 m, DBH height) (Fig. 2). At the center of each sub-plot, a smaller, concentric subplot of $6.2 \mathrm{~m}$ radius, and area of $30.1 \mathrm{~m}^{2}$ was established for the purpose of quantifying and measuring large and small pole-sized regeneration (with small poles having a DBH $0.1-2.9 \mathrm{~cm}$, and large poles a DBH of $3.0-11.9 \mathrm{~cm}$ ) (Fig. 2). Saplingsized individuals $(0.30 \mathrm{~m}$ to $1.37 \mathrm{~m}$ tall) were tallied and measured in three circular (1.3 m radius) smaller subplots centered at the edge of the adult subplot at 100, 200, and 300 degrees from plot center (Fig. 2). In the case that regeneration was prolific (i.e., more than $5 \mathrm{stems} / \mathrm{m}^{2}$ ), the subplot was divided into quarters and two of these sections were tallied for an estimate of overall stand regeneration density. 


\section{Tree Data}

Within each subplot type, all aspen were tallied by the four size classes and given a health status of 1 through 5 . The health status index was based on the apparent overall health of the tree. Factors included in the estimation of the health index score included presence of disease, insect, or abiotic damage, crown fullness, and apparent health of the vascular cambium. More specifically, status scores represented the following conditions: a score of a ' 1 ' indicated that the tree had little or no obvious disease or damage agents present (i.e., damage covering $0-25 \%$ of the bole or crown); a ' 2 ' indicated that the tree had minor to moderate damage to the crown or bole (i.e., damage covering $25-50 \%$ of the bole or crown); a ' 3 ' indicated that the tree had incurred severe damage to the crown or bole (i.e., damage covering $>50 \%$ of the bole or crown); a '4' indicated a recently dead tree (the tree was dead but the majority of the bark was intact, and fine twigs were present); a ' 5 ' indicated that the tree had been dead for more than five years (portions of the bark and fine twigs were absent). The first ten adult aspen in each plot were assessed for percent live crown, and the first ten individuals for all four size classes were assessed for disease and damage agents. In order to quantify the amount of insect or disease damage present, the bole and crown were carefully evaluated for percent extent of defoliation, cankers, conks, wounds, or any other disease or damage agents. When a disease or damage agent was detected, it was recorded as present and then assigned a severity score from 1 to 3 . A severity score of ' 1 ' indicated that the agent affected less than $25 \%$ of the crown or bole circumference; a ' 2 ' indicated that the agent affected between $25-50 \%$ of the crown or bole circumference; and a severity score of ' 3 ' indicated 
that the agent affected more than $50 \%$ of the crown or bole circumference. We also tallied by size class all non-aspen tree species in the plot, and noted whether they were living or dead.

Tree age was determined by coring at DBH height one adult dominant or codominant aspen in each sub-plot. One individual from each of the three regeneration size classes was also selected and destructively sampled and a cross section collected at ground level to determine age. Cores were placed in paper straws and regeneration crosssections placed in a paper bag and processed in the laboratory.

\section{Tree Cores \& Cross-sections}

Sample Processing

All cores and cross-sections were air-dried, sanded, and examined under a dissecting microscope to determine pith date. Cross-dating using the skeleton plot technique (Stokes and Smiley, 1968; Swetnam, et al, 1985), a graphical technique for comparing ring-width was used to determine relative growth and determining the narrowest rings.

\section{Tree Ring Measurements}

Annual rings widths, to nearest 1/100 millimeter were measured using an increnometer (Velmex, Inc, Bloomfield, NY, USA). The associated software program (J2X software, Velmex, Inc, Bloomfield, NY, USA) produces an rwl file as an output. This raw data was then checked using COFECHA, a simple DOS-based computer 
program that describes the accuracy of the chronology, or the correlation of each series (i.e., each core) with the master chronology (i.e., the average of individual dated cores for a specific area or region). Those series with correlations of less than 0.40 were separated into another file, and then re-run as 'undated' series against the group which had correlation values greater than 0.40 . The series with low correlations were corrected, and the two groups of measurements were combined and converted into a single dataset using the computer program YUX (Publisher).

\section{Drought Index Data}

To estimate the effect of drought conditions in Colorado and southern Wyoming for the period 1999-2008, we utilized a 4-km spatial drought index from the Forest Health Technology Enterprise Team (FHTET) with the U.S. Forest Service. These datasets were developed by Frank Koch and Bill Smith (U.S.F.S.) (manuscript in preparation), and utilized PRISM temperature and precipitation data, as well as calculations of potential evapotranspiration rates. PRISM datasets (The PRISM Climate Group, http://prism.oregonstate.edu/) are developed using weather station data and algorithms. Weather data from precise locations are extrapolated mathematically to predict weather conditions up to $4 \mathrm{~km}$ away, creating a gridded data set.

To obtain drought index conditions for each of our roadside and stand health survey locations for the years 1999-2008, we utilized the 'Sample' tool within the Spatial Analyst toolbox of ArcToolbox in ArcMap® (ESRI Inc., Redlands, CA). From this operation, an INFO table (non-spatial table) was produced, listing the UTM coordinates 
of each survey point, along with a drought index value from the gridded drought data set. This procedure was repeated for each annual dataset through 2008. Each INFO table was exported to a DATABASE format table, which is compatible for use with Microsoft Excel® (Microsoft Corp., Redmond, WA). Finally, individual files were compiled into a single spreadsheet for statistical analysis.

\section{Statistical Analysis}

All analyses were conducted using SAS 9.2 software (The SAS Institute Inc., Cary, NC). Data were analyzed based on whether it was considered plot- , transect-, or tree-level. For example, site conditions (such as slope and elevation) were analyzed at the transect- or plot-level, and disease and damage agent presence was analyzed at the tree level. Tree and plot data were averaged across the three survey plots for analysis.

\section{Roadside Survey Plot Data}

Data collected from roadside plots were analyzed using the PROC GLM and PROC GLIMMIX procedures in SAS to fit general linear models using an analysis of variance (ANOVA) and least-square means comparisons. In the PROC GLM procedure, both categorical and continuous variables were included as independent variables. Categorical variables used included: elevation, which was divided into four categories (by dividing the original elevation by 400); percent slope, which was divided into three categories, $0-9 \%, 10-20 \%$, and $>20 \%$; aspect was divided into the four cardinal directions. A single continuous variable, drought index, was also analyzed. The response 
variable used in this model was the square-root of the estimated stand mortality (i.e., the proportion of standing dead aspen within the stand).

In the PROC GLIMMIX procedure, the same four independent variables (elevation, slope, aspect, and drought index) were modeled. Response variables included: the presence of each of the three regeneration size classes; the presence of disease or insect damage; average percent live crown; and average stand mortality.

\section{Transect and Plot Data}

Site variables were analyzed as mixed linear models using the PROC GLIMMIX procedure. The response variables used included the proportion of live stems by size class, quadratic mean diameter (QMD), average tree health score, stand density, and trees per hectare (Eq 1-4).

Categorical variables (i.e., those used in the 'class' statement) used in all analyses included forest (or ranger district), healthy or damaged stand, and transect and plot number. Additional categorical variables used in the various statistical models included elevation, aspect, drought index, and select disease and insect presence and severity. Continuous variables included core increment widths, regeneration and adult tree ages, stand size (in hectares), and site index. Site index was calculated using the equation listed in the Appendix (Eq. 5). Survey plot elevation, measured in meters, ranged from 2200$3400 \mathrm{~m}$. The effect of elevation was analyzed as a categorical variable by dividing elevation by 400 and rounding the outcome off to the nearest integer (i.e., 6, 7, or 8). Survey plot aspect was categorized by degrees into the four cardinal directions. Drought index values for each transect were grouped into two periods, where values for 1999- 
2004 represented period one, and values for 2005-2008 represented period two. Values were grouped based on the assumption that the most recent episode of aspen dieback, if related to drought, is most likely related to the drier period, which occurred between 1999-2004, rather than the wetter period, which occurred between 2005-2008. Drought data was also analyzed yearly, with core increment data either matching yearly drought index data, or was staggered by one year (i.e., such that drought data was pared with core increment data from the following year). Core increment data was averaged across plots to the transect level, and merged with the drought index dataset prior to analysis. Regeneration and adult tree age was calculated by subtracting the pith date from 2008 . Age was then average by size class across plots to the transect level.

Due to differences in sample sizes (not all plots had core increment and regeneration sample data associated with them), the drought index/increment data was analyzed separately from the complete datasets (e.g., elevation, aspect). Random variables were transects within ranger districts (or forests) and plots within transects and ranger districts (or forests).

\section{Tree Data}

Tree data were also analyzed as mixed linear models using the PROC GLIMMIX program. The response variables used included: the proportion of stems with a particular disease or damage agent present; average health status among adult aspen; average percent live crown among adult aspen. Categorical variables included ranger district (or forest), healthy or damaged stand, disease or damage agent, and transect and plot number. Random variables were the same as those used in transect and plot data analysis. 


\section{Results}

\section{Roadside Survey Plots}

During 2009 and 2010, we established 573 road survey plots (i.e., rapid aspen health assessment plots) on eleven ranger districts within four national forests (Table 1). During analysis, a number of these plots were excluded due to insufficient data, recording errors, or other problems, resulting in a sample size of 500 (for the percent live analysis) and 573 (for the percent mortality, presence of regeneration, and presence of disease and insect damage). The Pike-San Isabel and White River national forests had the greatest numbers of survey plots (over 200 plots per forest), with fewer plots on the Routt and Medicine Bow national forests (Table 1). Fewer plots were established on the Routt and Medicine Bow national forests due to time and weather constraints.

Average stand mortality for a combination of all four size classes of aspen was generally less than $10 \%$ for most sites examined (Table 2). Average mortality was greatest at sites with moderate elevations (2400-2800 m), and those on north-facing aspects. Stands growing on sites located on toeslopes or valley bottoms had the lowest mortality among slope position categories. Among slope configuration categories, those sites with convex configurations had the highest mortality rates, as did sites with low (0$9 \%)$ or gentle $(10-19 \%)$ slope categories. Stands located east of the continental divide showed significantly higher mortality $(11 \%)$ than did those stand located west of the divide (4\%).

Average percent live crown was greatest on moderate- and high-elevation sites, contrary to percent stem mortality rates (Table 2). Percent live crown was also greatest among aspen stands located on toeslopes or valley bottoms, and on sites with gentle to moderate slopes (Table 2). Differences in percent average live crown among stands east 
and west of the continental divide were not significant, nor were the differences among ranger districts or national forests (omitting data from the Medicine Bow national forest) (Table 2).

Most aspen stands had at least three size classes. For example, sapling-, and largepole sized aspen were ubiquitous among all sites (Table 3); for this reason, no differences were detected in stem presence among the site variables. There were detectable differences among plots with respect to small pole-sized aspen stems. These were more likely to occur among stands in valley bottoms or on toeslopes (Table 3). Among ranger districts, stands on the South Park (Pike-San Isabel N.F.) and Blanco (White River N.F.) districts were least likely to contain small poles, and the Salida, San Carlos (both PikeSan Isabel N.F.), Yampa, Hahn's Peak, (both Routt N.F.), and Rifle (White River N.F.) districts were most likely to contain small poles (Table 3).

Insect damage among aspen stands (e.g., entrance holes of wood-boring insects, crown defoliation by various foliage-feeding species) was more occurred more frequently on sites east of the continental divide (Table 4). Insect damage was also more common among stands located on the Pike-San Isabel and White River National forests (Table 4). Evidence of disease agents (e.g., Cytospora, sootybark cankers) was very common among sites, with nearly $99 \%$ of sites visited showing evidence of infection (Table 4).

\section{Aspen Stand Assessment Plots}

During the 2009 field season, we established 49 transects on five ranger districts (South Park, Salida, Blanco, and Hahn's Peak ranger districts) within the Pike-San Isabel, White River, and Routt National Forests. We established an equal number of transects 
during the 2010 field season, on seven ranger districts (the San Carlos, Aspen-Sopris, Rifle, Yampa, Brush Creek-Hayden, Laramie, and Douglas ranger districts) within the Pike-San Isabel, White River, Routt, and Medicine Bow National forests. We collected tree density and size data and utilized three measures of aspen tree health including the percent live standing aspen (percent live aspen, Table 5)- a measure of current survival, a health index of $1-5$, and percent live crown- a continuous scale of standing live adult aspen crown density.

Aspen density varied significantly among the four national forests for small polesized and adult aspen; we found that more pole-sized trees were on the east vs. the west side of the continental divide, and we found fewer small poles on the Pike-San Isabel, Routt, and White River national forests than on the Medicine Bow (Table 5). The site factors that impacted aspen density included site aspect and slope configuration. Small pole-sized aspen were most common among stands on south- and west- facing aspects, and significantly more large pole-sized aspen among stands on east- and south-facing aspects (Table 5). The effect of slope configuration was significant with respect to stems per hectare among adult aspen; stands located on sites with a linear slope configuration had the most adult aspen stems (Table 5). In addition, we found that the average number of large pole-sized aspen was negatively correlated with average adult aspen age.

The least-squares means of the quadratic mean diameters for adult aspen $(>12 \mathrm{~cm}$ DBH) ranged from $20-28 \mathrm{~cm}$ over the four national forests. There was a significant difference between the diameter of adult aspen east and west of the divide (Table 6). Mean diameter of adults on the east side of the divide was less $(20.3 \mathrm{~cm})$ than those on the west $(25.1 \mathrm{~cm})$. The effect of stem age by size class with respect to quadratic mean 
diameter (QMD) was significant among adult aspen (Table 6). The QMD of adult aspen was positively correlated with adult age .

The least-squares means of percent live adult aspen was fairly uniform among the four national forests, ranging from $73-84 \%$, while taking into account the effect of various other factors, including district, stand type (i.e., healthy or damaged), continental divide position, and site factors (Table 7). There were significantly more live stems among 'healthy' stands, (82\%), than among 'damaged' stands (74\%). Aspect and elevation significantly affected the percent of live stems in the four aspen size classes. There were more living small pole-sized stems on low elevation sites than on moderateto high-elevation sites. There was a higher percent of live adult aspen stems on sites with north-facing aspects than those with west-facing aspects (Table 7). The effect of stem age in each size class with respect to the proportion of live stems per hectare was significant and negative among small- and large-sized poles and adult aspen (Table 7).

Average health index score ( 1 - 5 rating) of adult aspen was 1.7 among trees in healthy stands, and 2.3 among trees in damaged stands; health scores did not differ with respect to continental divide position (Table 8). The pattern was reversed among aspen saplings, which were healthier in damaged stands. Saplings differed in health status by the four national forests, with the healthiest on the Medicine Bow and White River national forests. Site factors that affected health status included elevation, aspect, and average adult aspen age (Table 8). Small pole-sized aspen were less healthy among stands on high elevation sites, and large pole-sized aspen most healthy among stands on low and high elevation sites. Overall, adult aspen among stands on west-facing slopes were less healthy than those growing on north- east-, and south- facing aspects (Table 8). 
This effect was not significant when adult aspen health was assessed with respect to percent live crown (see below).

The average percent live crown among adult aspen was fairly consistent among national forests and continental divide position (Table 9). Average live crown was higher among trees in healthy stands $(86 \%)$ than among those in damaged stands $(62 \%)$. Site variables that affected percent live crown included elevation and percent slope. Trees in stands on high elevation sites tended to have fuller crowns than trees on lower-elevation sites. Percent live crown was lowest among trees on sites with little to no slope, and greatest on sites with mild to moderate slopes (Table 9). The effect of stem age of aspen regeneration with respect to average percent live crown of adult aspen was significant among pole-sized aspen (Table 9). Average live crown among adult aspen was negatively correlated to average age of pole-sized aspen (i.e., the fuller the crown of the adult aspen, the younger the pole-sized regeneration).

\section{Biotic Effects: Presence of Insects and Diseases}

A total of fourteen different insect varieties or damage types were detected in the study. Of these, ten were present at very low levels (i.e., overall incidence of $n<15$ ) and were not subjected to in-depth analysis. Insects with low occurrence included: ambrosia beetles (Typodendron retusum), forest tent caterpillar (Malacosoma disstria), aspen leafminer (Phyllocnistis populiella), aspen blotchminer (Lithocolletis tremuloidiella), sawflies (Suborder Symphyta), leafhoppers (Idiocerus spp.), eriophyid mites (Eriophyes spp.), and aphids (Family Aphidae). Additionally, we lumped the bronze (Agrilus liragus) and poplar borer (Saperda calcarata) into a single category ('wood borers'), combined 
all foliage-feeding insects (e.g., the large aspen Tortrix (Choristoneura conflictana) into one general category ('foliage feeders'), and combined all leaf-tying insects into a single general category ('leaf tiers').

Fourteen phytopathogenic fungal agents were detected in the survey. Six of the fungal pathogens were present at very low levels and were not subjected to in-depth analysis and included the decay fungi Peniophora polygonia and Armillaria ostoyae; the root disease Ganoderma applanatum; the foliar fungi Ciborinia spp., Melampsora medusa; and the canker fungus Dothiora polyspora. Likewise, thirteen types of animal damage were detected, and seven types of abiotic damage. Of these two categories, sixteen were present at very low levels and were not subjected to in-depth analysis. The low incidence damage included antler rubbing, moose feeding, rodent feeding, porcupine feeding, beaver damage, birds feeding, birds nesting, human damage, lighting, sunscald, drought stress, and frost crack. Note that some damage categories were combined (e.g., rodent feeding, bark and stem). See Table 16 for a complete list of disease and damage agents.

Insect Damage Agents

We found wood-boring insects and bark beetles to be the most commonlyoccurring insects, with $5-41 \%$ of the trees on the four national forests showing evidence of wood borers or bark beetles(Table 12).

The presence of wood boring insects on aspen was significant with respect to elevation, stand type, national forest, percent slope, and slope configuration (Table 12). In general, trees on sites that were of moderate elevation (2600-2900 m), located on steep 
(>50\%) slopes with concave or undulating configurations had the highest prevalence of wood-boring insects (Table 12). Furthermore, trees on the Pike-San Isabel and Medicine Bow national forests had the greatest rate of wood borer evidence, followed by the White River and Routt national forests (Table 12).

The presence of bark beetles on aspen differed significantly among all four national forests, stand types, continental divide position, and the five site parameters (Table 12). There were significantly more trees with bark beetles in damaged stands than in healthy stands (16\% and 7\%, respectively) (Table 12$)$. There were also significantly more beetles among aspen on the Pike-San Isabel national forest (41\%) than on the Medicine Bow, Routt, or White River National forests ( $0 \%, 10 \%$, and 5\%, respectively) (Table 12). Beetle-infested trees were more prevalent on low-elevation sites, sites positioned on summits or shoulder slopes, on sites with no or low slopes, on sites with concave slope configurations, and on sites east of the continental divide (Table 12).

The prevalence of foliage-feeding insect damage (i.e., foliage feeders and leaf tiers in Table 12) was significantly influenced by elevation, aspect, stand type, continental divide position, site percent slope, and site slope configuration (Table 12). Foliar damage was more common among trees in damaged stands, on stands west of the continental divide, on sites with gentle slopes, moderate-elevation sites, and those with north- or east-facing aspects (Table 12).

Disease Damage Agents

Cytospora canker, Marssonina foliar blight, and the decay fungus Phellinus tremulae (Bond.) Bond. and Borisov were the only diseases that occurred with enough 
frequency among all four size classes of aspen (i.e., $n \geq 100$ trees) to be included in the final analysis. The prevalence of Cytospora canker on aspen was significantly influenced by stand type, continental divide position, national forest, percent slope of the site, and slope configuration (Table 10). In general, trees in 'damaged' stands east of the continental divide, with slopes of $10 \%$ or less and having slope configurations of broken, concave, or convex had the highest prevalence of Cytospora canker. The average severity rating of Cytospora canker was generally high (> 2.5), and did not vary significantly by site variables (Table 14). Canker severity differed only among national forest, and was less severe on the Medicine Bow compared with the other three forests (Table 14).

The presence of Marssonina leaf blight was influenced by all parameters except for site slope position (Table 10). It should be noted that symptoms of this foliar blight become evident in late summer, and that during each of our field seasons, we surveyed the northern-most forests at the end of the season. Thus, Marssonina could well have been present in stands in the southern part of our survey area, and was not detected due to the time of year that those areas were surveyed. Nonetheless, Marssonina was most common among trees on sites with low elevation, north- or west-facing aspects, on sites west of the divide, on sites with concave slope configuration, and among trees on damaged stands (Table 10). The severity of Marssonina leaf blight infestation among aspen was influenced by elevation, stand type, divide position, and site percent slope (Table 14). Trees in high elevation sites tended to have more severe blight infection than those on moderate or low sites; conversely, trees on north-facing sites had the least severe outbreaks, as did trees on sites with undulating slope configuration. 
The presence of Phellinus tremula (white trunk rot) on aspen was influenced by elevation, aspect, continental divide position, national forest, and site slope configuration (Table 11). White trunk rot was generally more prevalent trees on sites west of the divide, on north- or west-facing aspects, and on sites with concave slope configurations. The severity of white trunk rot on aspen was not significantly influenced by any of the eight parameters included in the analysis (Table 14).

The three other canker diseases subjected to complete analysis-Ceratocystis, Cryptosphaeria, and Encoelia- and the one other blight disease (Venturia) occurred at a rate of $1-2 \%$ among all size classes of aspen (Tables 10 and 11). Although there are some statistically significant differences in the prevalence of these diseases, prevalence remained very low.

Black canker (Ceratocystis fimbriata) prevalence was low overall, but was influenced by elevation, aspect, stand type, divide position, slope position, and percent slope (Table 10). Overall, black canker was more frequently observed on trees on high-elevation sites on toeslopes or valley bottoms. The Routt and White River national forests had the lowest incidences of this disease (Table 10). Sooty bark canker (Encoelia pruinosa) prevalence was low overall, but greater among trees in 'damaged' stands (Table 10). The prevalence of Cryptosphaeria canker among aspen was influenced by national forest (Table 10). Virtually no Cryptosphaeria canker was detected on the Medicine Bow and White River national forests. The presence of Shepherd's Crook (Venturia tremulae) was influenced by aspect and site percent slope (Table 11). Trees on sites with north-facing aspects and on sites of moderate to steep slopes were more likely to have Shepherd's Crook. 
We detected Armillaria root rot on dead aspen in 64\% of plots (Table 17). Among stands where Armillaria was detected on dead trees, it was also detected on live trees $11 \%$ of the time (Table 17). There was no apparent relationship between presence of this disease and site or stand characteristics (data not shown).

\section{Abiotic and other damages:}

The prevalence of fire scars among aspen was infrequent, though fire scars were more common among trees on moderate- and high-elevation sites (Table 13). Although analysis indicated significant influence of other parameters, estimates were too small to be useful.

The prevalence of fire scars among aspen was influenced by elevation, Continental Divide position, national forest, slope position, percent slope, and slope configuration (Table 13). Wounds of unknown origin were more common on trees in high-elevation sites, sites west of the divide, and sites with steep slopes, toeslopes, and undulating or broken slope configurations (Table 13).

The prevalence of branch galls among aspen was influenced by elevation, Continental Divide position, national forest, and percent slope (Table 13). Although analysis indicated significant influence of other parameters, estimates were too small to be useful.

The prevalence of ungulate bark browsing was influenced by elevation, stand type, Continental Divide position, national forest, slope position, percent slope, and slope configuration (Table 13). Trees on sites east of the divide were more likely to have 
evidence of bark browsing, as were trees in 'damaged' stands, and those on the Pike- San Isabel national forest.

Three environmental factors were analyzed with respect to average stem age by size class. There were no significant factors in any of the analyses performed (Table 15). Age of large and small poles were not different from each other, and were about 28 years old, whereas saplings averaged 5 years old, and adult aspen averaged 91 years old (Table $15)$.

Tree Growth and Drought:

Drought index data was analyzed for the period of January 1999 through December 2008 with respect to adult aspen annual increment data for the same period. No significant relationships were detected. We also analyzed the same two datasets by calculating the relative drought and increments between 2002 and the average of 1999 and 2000. This was based on the observation of the graphed drought index data, which indicated a moderate drought in 2002. We hypothesized that the trees would respond quickly to the drought, and that they would likewise show a significant decrease in growth for 2002 compared with the 1999 and 2000 growing seasons. There were differences in increment growth between national forests (data not shown), but the relationship between increment and drought index was not significant. More work is needed to determine whether the lack of relationship between growth increment and drought index is due to small sample size (of increment cores), errors in increment measurement, or drought index data resolution. 
Stand site index was analyzed for most transects, where adult aspen age had been determined. There were no significant relationships between any of the stand density (proportion live stems, QMD, stems per hectare) or tree health (average health status, percent live crown) variables tested against site index (data not shown). 


\section{Discussion}

\section{Roadside Survey}

Overall, analysis of the data collected from the roadside survey portion of this study does not clearly indicate any single factor influencing stand health. Analysis of data collected during the aspen health survey indicates that the structure of stands throughout the four national forests surveyed is consistent. There were, however differences in the prevalence of small pole-sized aspen at the district level. These differences may point to specific site and environmental factors not detected at the forest-level scale. Based on survey plot data from the same districts, such factors could include heavy grazing of young aspen by elk or cattle; a particularly dense understory, which could prevent regeneration from occurring keeping soil temperatures low; lack of a disturbance event in recent history that would have triggered a regeneration cohort.

Average stand mortality over all four size classes was consistent across national forests (if data from the Medicine Bow are assumed to be fundamentally different from data collected on the other three national forests), and ranged from $3-4 \%$. This rate is lower than mortality rates noted by aerial survey, where the area impacted ranged from $0.05-14 \%$ of the total aspen covertype (Table 19). The mortality rate is also lower than that found by Steed and Kearns (2010) in Montana and Idaho, and consistent with those found by Hogg, et al (2008) in western Canada. Among ranger districts, there were significant differences in average stand mortality; districts surveyed in 2009 tended to have higher mortality estimates, which could be attributed to either (1) that these districts experienced more aspen damage than did the other districts in the survey, (2) surveyor error or inexperience. Specifically, mortality data collected from the Medicine Bow 
national forest is higher by nearly a factor of ten, so caution should be used in including it in final conclusions. Among ranger districts, stands located on the South Park and Blanco districts showed the highest average mortality (Table 2).

We found that stands occurring on high-elevation sites, on sites with convex slope configurations, and those on sites east of the continental divide experience higher levels of stand mortality than those occurring on other site types. At the same time, stands on moderate- and high-elevation sites had fuller crowns, as did stands occurring on sites located on toeslopes and valley bottoms, and those with no to low slopes. Considering that stands experienced both increased morality and fuller adult aspen crowns at moderate- and high-elevation sites, it may be that these stands are simply more mature; the understory aspen cohorts are undergoing natural dieback as the adult cohort thrives. It's very possible that the observed increased mortality rates may simply be due to better growing conditions; stands in which adult aspen are growing vigorously will tend to have more morality in the understory as the canopy fills out and regeneration receives less light.

Other results from this analysis point to possible water relations: areas east of the continental divide are generally drier than those on the west; toeslopes and valley bottom sites (and low percent slopes) most likely are wetter than those on backslopes or summit areas with greater percent slopes; sites with convex slope configurations may well experience drier conditions than those with other configurations. Analysis of insect and disease presence among the aspen we surveyed with roadside survey plots did not indicate any significant relationships between any of the environmental or site conditions 
-except for disease prevalence among national forests and continental divide position, which we attribute to differences in surveyor perception, and are thus not true effects.

Aspen Stand Assessment Plots:

Contrary to our initial hypothesis, analysis of survey data indicated that there were significant differences among stands east and west of the continental divide. Adult aspen west of the divide tended to have larger diameters and fuller crowns than adult aspen east of the divide. However, stands east of the divide had on average more adult stems per hectare, more live saplings per plot, and healthier saplings than did stands west of the divide. A study of aspen in Montana and Idaho by Steed and Kearns (2010) did not show any difference in aspen mortality or stand density east and west of the continental divide.

Analysis of stand survey data indicated that, although there were significant differences in adult aspen mortality and insect and disease prevalence among aspen in 'healthy' vs. 'damaged' stands, it appears likely that aspen will persist on most sites. The main differences between the two stand types (i.e., healthy and damaged) included: proportions of live adults; average health status among sapling- and adult-size aspen; presence of ungulate browsing; presence of bark beetles, wood borers, leaf-tying insects and general foliage feeding insects; presence of canker-causing fungi, especially Cytospora; and the damage severity rating of Marssonina leaf blight. Observed prevalence of Cytospora canker in this study was much higher than in a recent survey of aspen health in the Northern Rocky Mountains (Steed and Kearns, 2010). We observed 
Phellinus conk at a rate of about $4 \%$, where stands in the northern rocky mountain area have infection rates of $10-11 \%$ (Steed and Kearns, 2010).

In general, damaged aspen stands contained fewer total adult aspen stems, and fewer live adult aspen stems. Further, average health status and proportion live crown was lower among adult aspen in damaged stands. This was expected because 'damaged' stands were identified from aerial surveys based on stand mortality and crown dieback. Likewise, during surveying, damaged stands were selected because they were clearly less healthy than adjacent stands. Disease prevalence among damaged stands was not detected during aerial surveys, and thus was not used in stand classification. Survey data indicates that damaged stands contained significantly more Cytospora (Valsa spp), sooty bark (Encoelia pruinosa), and black (Ceratocystis) cankers, wood-boring insects (Agrilus liragus Barter \& Brown and Saperda calcarata), aspen bark beetles (Trypophloeus populi and Procryphalus mucronatus (LeConte)), and leaf-tying insects than healthy stands. Three diseases, Shepherd's Crook (Venturia tremulae), Phellinus conk, and Cryptosphaeria canker, were not significantly more prevalent among damaged stands. Prevalence of Cytospora canker was greater among stands east of the Divide, but Phellinus decay, branch galls, leaf-tying insects, damage from foliage-feeding insects, and Shepherd's Crook shoot blight were more common among stands west of the Divide. These findings support the hypothesis that stands east of the Divide are more likely to experience drought conditions, and thus, the prevalence of disease and damage agents frequently found on drought-stressed trees (e.g., Cytospora canker) would likely be greater under such conditions. Conversely, stands west of the Divide are likely to be wetter than those on the east, and thus the prevalence of diseases associated with wet 
conditions (e.g., Shepherd's Crook blight) would be greater west of the Divide. Compared with the current study, Brandt et al (2003) found much lower rates of wood borer damage ( $3 \%$ vs. $20 \%$ ) and comparable rates of Armillaria root decay (14\% vs. $11 \%$ ) in their survey of aspen stands across central and western Canada.

Among aspen stands in the national forests surveyed, there were several significant differences. Saplings and small pole-sized stems occurred at the highest densities and were healthier overall on sites in northern-most forests, including the Medicine Bow and Routt national forests. Since regeneration class was based solely on diameter or height, it's possible that small poles were more common on the Blanco and South Park districts than recorded, but were growing at a faster or slower rate than other sites, putting them in the large pole or sapling size classes.

Among adult aspen, crowns were fullest on sites located in the Routt and White River National Forests, which are located west of the Continental Divide, and among stands on moderate- and high-elevation sites. This may be due to the wetter conditions generally found on these sites. Likewise, stands located on flat sites may be subject to flooding events, and the root systems among trees in these stands could be shallower than those on steeper slopes, making them more vulnerable to periods of drought. Stands with higher live crown percentages also tended to have higher mortality rates (Table 2). This apparent discrepancy is most likely due to the fact that aspen stands with fuller crowns tend to have more understory mortality. Aspen self-thin as the stand ages; adults fill the canopy and reduce the amount of light reaching the forest floor. Any regeneration present eventually dies. 
Overall, our data suggests that aspen stands throughout Colorado experience varying degrees of environmental stress and disease and insect damage. This is indicated by the increased rates of adult stem mortality among stands east of the continental divide (which tends to be drier than the west) and the increased presence of such stress-related organisms as Cytospora canker aspen bark beetles, and poplar borers among damaged stands. Other recent studies of aspen mortality throughout western North America have attributed the observed mortality to acute drought conditions (Worrall, et al, 2008 \& 2010; Fairweather, 2008; Hogg, et al, 2008). Acute drought is most likely the main inciting factor, though further analysis is required to definitively link the marked increase in select damage agents with moisture deficit. In spite of this, many stands recently classified as damaged will likely persist on the landscape, as indicated by the high proportions of live regeneration among both damaged and healthy stands, and the low proportion of damaged aspen stands to total aspen area.

This is not surprising, because aspen self-thin as the stand ages; adults fill the canopy and reduce the amount of light reaching the forest floor. Any regeneration present eventually dies. 
Table 1. Numbers of roadside survey plots ${ }^{1}$ established in aspen stands in Colorado, 2009 - 2010

\begin{tabular}{|c|c|c|c|}
\hline National Forest & Ranger District & $\begin{array}{c}\text { Number of } \\
\text { Roadside Plots }\end{array}$ & Year Surveyed \\
\hline \multirow[t]{5}{*}{ Pike-San Isabel } & \multicolumn{3}{|c|}{216} \\
\hline & South Park & 48 & 2009 \\
\hline & Salida & 52 & 2009 \\
\hline & Pike & 70 & 2010 \\
\hline & San Carlos & 46 & 2010 \\
\hline \multirow[t]{4}{*}{ White River } & \multicolumn{3}{|c|}{203} \\
\hline & Blanco & 45 & 2009 \\
\hline & Rifle & 50 & 2010 \\
\hline & Aspen-Sopris & 108 & 2010 \\
\hline \multirow[t]{3}{*}{ Routt } & \multicolumn{3}{|c|}{114} \\
\hline & Hahn's Peak & 54 & 2009 \\
\hline & Yampa & 60 & 2010 \\
\hline \multirow[t]{4}{*}{ Medicine Bow } & \multicolumn{3}{|c|}{88} \\
\hline & Laramie & 78 & 2010 \\
\hline & Brush Creek-Hayden & 10 & 2010 \\
\hline & Brush Creek-Hayden & 10 & 2010 \\
\hline
\end{tabular}


Table 2. Average percent mortality and live crown of aspen from a roadside survey, in Colorado, 2009 - 2010

\begin{tabular}{|c|c|c|c|c|c|c|c|}
\hline \multirow{3}{*}{\multicolumn{2}{|c|}{ Independent Variable }} & \multirow{2}{*}{\multicolumn{3}{|c|}{$\begin{array}{l}\mathbf{y}=\text { Average Stand Mortality } \\
\mathbf{n}=\mathbf{5 7 3}^{2}\end{array}$}} & \multirow{2}{*}{\multicolumn{3}{|c|}{$\begin{array}{c}y=\text { Average Live Crown } \\
n=500^{2}\end{array}$}} \\
\hline & & & & & & & \\
\hline & & \multirow[t]{2}{*}{ LS Mean $^{1}$} & \multirow[t]{2}{*}{$\begin{array}{l}\text { Lower } \\
\text { C.I. }\end{array}$} & \multirow[t]{2}{*}{$\begin{array}{l}\text { Upper } \\
\text { C.I. }\end{array}$} & \multirow[t]{2}{*}{$\begin{array}{c}\text { LS } \\
\text { Mean }^{1}\end{array}$} & Lower C.I. & $\begin{array}{l}\text { Upper } \\
\text { C.I. } \\
\end{array}$ \\
\hline \multicolumn{4}{|c|}{ Elevation } & & & & \\
\hline & Low & $7.1 \mathrm{a}$ & 6.22 & 8.05 & $85.8 \mathrm{a}$ & 83.90 & 87.80 \\
\hline & Moderate & $6.6 a b$ & 5.81 & 7.43 & $90.2 b$ & 88.33 & 92.01 \\
\hline & High & $8.1 \mathrm{~b}$ & 6.94 & 9.33 & $93.9 \mathrm{~b}$ & 91.18 & 96.57 \\
\hline \multicolumn{8}{|l|}{ Aspect } \\
\hline & North & 7.9 & 6.96 & 8.88 & $85.7 \mathrm{a}$ & 83.71 & 87.70 \\
\hline & East & 7.3 & 6.43 & 8.25 & $90.0 \mathrm{~b}$ & 88.00 & 92.13 \\
\hline & South & 6.7 & 5.90 & 7.57 & $92.1 \mathrm{~b}$ & 90.18 & 93.97 \\
\hline & West & 7.1 & 6.20 & 8.11 & $92.0 \mathrm{~b}$ & 89.85 & 94.10 \\
\hline \multicolumn{8}{|l|}{ Slope Position } \\
\hline Summit- & Shoulder Slope & $8.3 \mathrm{~b}$ & 7.22 & 9.37 & $88.0 \mathrm{a}$ & 85.68 & 90.26 \\
\hline Back & lope-Footslope & $8.5 b$ & 7.70 & 9.40 & $87.0 \mathrm{a}$ & 85.28 & 88.64 \\
\hline Toeslope & Valley Bottom & $5.2 \mathrm{a}$ & 4.38 & 6.13 & $95.0 \mathrm{~b}$ & 92.70 & 97.27 \\
\hline \multicolumn{8}{|c|}{ Slope Configuration } \\
\hline & Broken & $5.0 \mathrm{ab}$ & 2.61 & 8.15 & $93.1 \mathrm{ab}$ & 85.97 & 100.00 \\
\hline & Concave & $6.7 \mathrm{a}$ & 6.07 & 7.41 & $90.3 \mathrm{~b}$ & 88.72 & 91.95 \\
\hline & Convex & $10.1 \mathrm{c}$ & 9.22 & 10.94 & $87.0 \mathrm{a}$ & 85.26 & 88.68 \\
\hline & Linear & 7.0ab & 6.41 & 7.72 & $90.3 \mathrm{~b}$ & 88.85 & 91.83 \\
\hline & Undulating & $7.9 \mathrm{~b}$ & 7.18 & 8.66 & $88.9 \mathrm{ab}$ & 87.33 & 90.53 \\
\hline \multicolumn{8}{|l|}{ \% Slope } \\
\hline & $0-9 \%$ & $8.4 \mathrm{~b}$ & 7.43 & 9.36 & $87.6 \mathrm{a}$ & 85.55 & 89.58 \\
\hline & $10-19 \%$ & 7.6ab & 6.70 & 8.50 & $91.8 \mathrm{~b}$ & 89.87 & 93.76 \\
\hline & $20-29 \%$ & $6.7 \mathrm{a}$ & 5.79 & 7.58 & $91.0 \mathrm{abc}$ & 88.87 & 93.08 \\
\hline & $30-39 \%$ & $6.7 \mathrm{a}$ & 5.78 & 7.71 & $89.6 \mathrm{bc}$ & 87.35 & 91.88 \\
\hline & $\geq 40 \%$ & 7.0ab & 5.65 & 8.55 & $89.7 b$ & 86.53 & 92.98 \\
\hline \multicolumn{8}{|c|}{ Continental Divide } \\
\hline & East & $11.2 \mathrm{~b}$ & 10.07 & 12.35 & 89.3 & 87.25 & 91.31 \\
\hline & West & $4.2 \mathrm{a}$ & 3.56 & 4.83 & 90.6 & 88.76 & 92.41 \\
\hline \multicolumn{8}{|l|}{ Forest (Divide) } \\
\hline \multirow[t]{2}{*}{ East } & Med. Bow & $23.7 \mathrm{c}$ & 21.32 & 26.22 & $85.2 \mathrm{a}$ & 82.32 & 88.04 \\
\hline & Pike-San Is. & $3.3 \mathrm{a}$ & 2.75 & 3.92 & $93.5 \mathrm{c}$ & 91.53 & 95.47 \\
\hline \multirow[t]{2}{*}{ West } & Routt & $3.8 \mathrm{ab}$ & 3.10 & 4.47 & $92.0 \mathrm{bc}$ & 89.87 & 94.07 \\
\hline & Wht River & $4.6 \mathrm{~b}$ & 3.94 & 5.33 & $89.2 \mathrm{ab}$ & 87.34 & 91.11 \\
\hline \multicolumn{8}{|c|}{ District (Forest * Divide) } \\
\hline \multirow[t]{2}{*}{ Med. Bow } & $\mathrm{BCH}^{*}$ & $30.8 \mathrm{f}$ & 26.55 & 35.43 & 91.7bd & 87.07 & 96.48 \\
\hline & Laramie & $17.5 \mathrm{e}$ & 15.75 & 19.38 & $78.8 \mathrm{a}$ & 76.47 & 81.23 \\
\hline \multirow[t]{4}{*}{ Pike-San Is. } & Pikes Peak & $3.3 \mathrm{bc}$ & 2.68 & 4.07 & $89.9 \mathrm{~b}$ & 87.67 & 92.10 \\
\hline & Salida & $2.0 \mathrm{a}$ & 1.41 & 2.66 & - & - & - \\
\hline & Sa n Carlos & $2.4 \mathrm{ab}$ & 1.80 & 3.06 & $97.2 \mathrm{~d}$ & 94.73 & 99.66 \\
\hline & South Park & $6.2 \mathrm{~d}$ & 4.78 & 7.83 & - & - & - \\
\hline Routt & Hahn's Pk & $4.6 \mathrm{~cd}$ & 3.78 & 5.56 & $88.5 b$ & 86.15 & 90.92 \\
\hline & Yampa & $3.0 \mathrm{ab}$ & 2.30 & 3.73 & $95.5 \mathrm{~d}$ & 92.97 & 97.98 \\
\hline White River & Aspen-Sopris & $3.3 b c$ & 2.68 & 3.97 & $89.7 b$ & 87.64 & 91.79 \\
\hline & Blanco & $7.6 \mathrm{~d}$ & 6.48 & 8.84 & $85.7 b$ & 83.26 & 88.13 \\
\hline & Rifle & $3.5 b$ & 2.67 & 4.40 & 92.3bd & 89.58 & 95.10 \\
\hline
\end{tabular}

${ }^{1}$ Least-squares means are presented as they were analyzed against eight site and environmental parameters.

${ }^{2}$ During analysis, between 48-121 plots were excluded due to insufficient data or other problems, resulting in a sample size of 500 (for the percent mortality analysis) and 573 (for the percent live crown analysis).

Average mortality was estimated based on the proportion of dead standing aspen in all size classes compared to the approximate total standing aspen within the plot. Average percent live crown was estimated based on the approximate mean live crown of all standing aspen with $\mathrm{DBH}>11.9 \mathrm{~cm}$ within the plot.

$* \mathrm{BCH}=$ Brush Creek-Hayden ranger district.

Significant differences between means are indicated by letters; means with different letters are significantly different from each other at the $\mathrm{P} \leq 0.05$ level. 
Table 3 A-D. Average percent frequency ${ }^{1}$ of three regeneration size classes of aspen from roadside survey plots ${ }^{2}$, in Colorado, 2009 - 2010

$3 \mathbf{3}$.

\begin{tabular}{|l|c|c|c|c|c|c|c|c|}
\cline { 3 - 9 } \multicolumn{2}{c|}{} & \multicolumn{3}{c|}{ Elevation* } & \multicolumn{4}{c|}{ Aspect } \\
\hline Size Class & $\mathbf{n}$ & $\begin{array}{c}\text { Low } \\
\%(\text { SE) }\end{array}$ & $\begin{array}{c}\text { Moderate } \\
\%(\text { SE) }\end{array}$ & $\begin{array}{c}\text { High } \\
\%(\text { SE) }\end{array}$ & $\begin{array}{c}\text { North } \\
\%(\text { SE) }\end{array}$ & $\begin{array}{c}\text { East } \\
\%(\text { SE) }\end{array}$ & $\begin{array}{c}\text { South } \\
\%(\text { SE) }\end{array}$ & $\begin{array}{c}\text { West } \\
\%(\text { SE) }\end{array}$ \\
\hline Saplings & 573 & $(253.5)$ & $99(99.0)$ & $99(52.5)$ & $98(139.2)$ & $98(117.8)$ & $99(71.9)$ & $99(125.1)$ \\
\hline Small Poles & 573 & $80(2.1)$ & $83(1.7)$ & $86(2.0)$ & $84(1.8)$ & $88(1.4)$ & $80(2.0)$ & $78(2.6)$ \\
\hline Large Poles & 573 & $100(0.0)$ & $100(0.0)$ & $100(0.0)$ & $100(0.0)$ & $100(0.0)$ & $100(0.0)$ & $100(0.0)$ \\
\hline
\end{tabular}

$3 B$.

\begin{tabular}{|c|c|c|c|c|c|c|c|}
\hline \multicolumn{3}{|c|}{ Slope Position* } & \multicolumn{5}{c|}{ Slope Configuration } \\
\hline $\begin{array}{c}\text { Summit- } \\
\text { Shoulder } \\
\%(\text { SE) }\end{array}$ & $\begin{array}{c}\text { Backslope- } \\
\text { Footslope } \\
\%(\text { SE) }\end{array}$ & $\begin{array}{c}\text { Toeslope- } \\
\text { Valley } \\
\%(\text { SE) }\end{array}$ & $\begin{array}{c}\text { Broken } \\
\%(\text { SE) }\end{array}$ & $\begin{array}{c}\text { Concave } \\
\%(\text { SE) }\end{array}$ & $\begin{array}{c}\text { Convex } \\
\%(\text { SE) }\end{array}$ & $\begin{array}{c}\text { Linear } \\
\%(\text { SE) }\end{array}$ & $\begin{array}{c}\text { Undulating } \\
\%(\text { SE) }\end{array}$ \\
\hline $98(155.4)$ & $99(87.3)$ & $99(98.9)$ & $100(0.0)$ & $78(1.9)$ & $88(1.3)$ & $84(1.6)$ & $83(1.6)$ \\
\hline $72 \mathrm{a}(2.8)$ & $78 \mathrm{a}(1.8)$ & $93 \mathrm{~b}(1.2)$ & $64(9.5)$ & $87(0.04)$ & $85(1.5)$ & $88(1.2)$ & $85(1.5)$ \\
\hline $100(0.0)$ & $100(0.0)$ & $100(0.0)$ & $100(0.0)$ & $100(0.0)$ & $100(0.0)$ & $100(0.0)$ & $100(0.0)$ \\
\hline
\end{tabular}

3C.

\begin{tabular}{|c|c|c|c|c|c|c|c|c|c|c|}
\hline \multicolumn{5}{|c|}{ \% Slope } & \multicolumn{2}{|c|}{$\begin{array}{c}\text { Continental } \\
\text { Divide Position* }\end{array}$} & \multicolumn{4}{|c|}{ National Forest* } \\
\hline $\begin{array}{c}0-9 \% \\
\%(\mathrm{SE} \\
)\end{array}$ & $\begin{array}{c}10- \\
19 \% \\
\%(\mathrm{SE} \\
\text { ) }\end{array}$ & $\begin{array}{c}20- \\
29 \% \\
\%(\mathrm{SE})\end{array}$ & $\begin{array}{c}30- \\
39 \% \\
\% \text { (SE } \\
\text { ) }\end{array}$ & $\begin{array}{c}\geq \\
40 \% \\
\%(\mathrm{SE} \\
\text { ) }\end{array}$ & $\begin{array}{c}\text { East } \\
\%(\mathbf{S E} \\
\text { ) }\end{array}$ & $\begin{array}{c}\text { West } \\
\%(\text { SE) }\end{array}$ & $\begin{array}{c}\text { Medici } \\
\text { ne Bow } \\
\%(\mathrm{SE})\end{array}$ & $\begin{array}{c}\text { Pike-San } \\
\text { Isabel } \\
\%(\text { SE) }\end{array}$ & $\begin{array}{l}\text { Routt } \\
\% \text { (SE } \\
\text { ) }\end{array}$ & $\begin{array}{l}\text { White } \\
\text { River } \\
\text { \%(SE) }\end{array}$ \\
\hline $\begin{array}{c}99 \\
(82.3) \\
\end{array}$ & $\begin{array}{c}99 \\
(90.9) \\
\end{array}$ & $\begin{array}{c}99 \\
(119.3) \\
\end{array}$ & $\begin{array}{c}97 \\
(215.2 \\
\quad)\end{array}$ & $\begin{array}{c}99 \\
(84.1) \\
\end{array}$ & $\begin{array}{c}99 \\
(62.4) \\
\end{array}$ & $\begin{array}{c}98 \\
(193.2) \\
\end{array}$ & $\begin{array}{c}100 \\
(17.3)\end{array}$ & $97(219.4)$ & $\begin{array}{c}98 \\
(146.7 \\
\quad) \\
\end{array}$ & $\begin{array}{c}97 \\
(253.8) \\
\end{array}$ \\
\hline $\begin{array}{c}81 \\
(1.9) \\
\end{array}$ & $\begin{array}{c}85 \\
(1.6) \\
\end{array}$ & $84(1.8)$ & $\begin{array}{c}81 \\
(2.2) \\
\end{array}$ & $\begin{array}{c}83 \\
(3.0) \\
\end{array}$ & $\begin{array}{c}84 \\
(1.8) \\
\end{array}$ & $82(1.8)$ & $90(2.0)$ & $76(2.2)$ & $\begin{array}{c}83 \\
(2.1) \\
\end{array}$ & $80(1.9)$ \\
\hline $\begin{array}{r}100 \\
(0.0)\end{array}$ & $\begin{array}{r}100 \\
(0.0)\end{array}$ & $\begin{array}{r}100 \\
(0.0)\end{array}$ & $\begin{array}{r}100 \\
(0.0)\end{array}$ & $\begin{array}{r}100 \\
(0.0)\end{array}$ & $\begin{array}{r}100 \\
(0.0)\end{array}$ & $\begin{array}{r}100 \\
(0.0)\end{array}$ & $\begin{array}{r}100 \\
(0.0)\end{array}$ & $100(0.0)$ & $\begin{array}{r}100 \\
(0.0)\end{array}$ & $100(0.0)$ \\
\hline
\end{tabular}


$3 D$.

\begin{tabular}{|c|c|c|c|c|c|c|c|c|c|c|}
\hline \multicolumn{11}{|c|}{ Ranger District (Forest * Divide)* } \\
\hline $\begin{array}{l}\text { BCH*** } \\
\%(\mathrm{SE})\end{array}$ & $\begin{array}{l}\text { Lar: } \\
\%(\end{array}$ & $\begin{array}{l}\text { Pike's } \\
\text { Peak } \\
\%(\text { SE) }\end{array}$ & $\begin{array}{l}\text { Salida } \\
\%(\text { SE) }\end{array}$ & $\begin{array}{c}\text { San } \\
\text { Carlos } \\
\%(\text { SE) } \\
\end{array}$ & $\begin{array}{c}\text { South } \\
\text { Park } \\
\%(\text { SE })\end{array}$ & $\begin{array}{c}\text { Hahn's } \\
\text { Peak } \\
\%(\text { SE) }\end{array}$ & & $\begin{array}{l}\text { Aspen- } \\
\text { Sopris } \\
\%(\mathrm{SE})\end{array}$ & E) & $\begin{array}{l}\text { Rifle } \\
\%(\text { SE) }\end{array}$ \\
\hline $\begin{array}{c}99 \\
(54.6)\end{array}$ & 100 & $\begin{array}{c}99 \\
(53.8)\end{array}$ & $\begin{array}{c}97 \\
(264.2)\end{array}$ & $\begin{array}{c}99 \\
(96.3)\end{array}$ & $\begin{array}{c}82 \\
(127.2)\end{array}$ & $\begin{array}{c}99 \\
(124.4)\end{array}$ & $\begin{array}{c}98 \\
(172.2)\end{array}$ & $\begin{array}{c}98 \\
(201.8)\end{array}$ & $\begin{array}{c}94 \\
(452.0)\end{array}$ & $\begin{array}{c}98 \\
(175.5)\end{array}$ \\
\hline $\begin{array}{l}92 \mathrm{bcd} \\
(2.8) \\
\end{array}$ & $\begin{array}{c}88 \mathrm{bcd} \\
(2.0)\end{array}$ & $\begin{array}{c}76 \mathrm{bcd} \\
(2.5)\end{array}$ & $\begin{array}{c}89 \mathrm{bcd} \\
(1.9) \\
\end{array}$ & $\begin{array}{c}78 \mathrm{bcd} \\
(2.6)\end{array}$ & $\begin{array}{l}50 \mathrm{ad} \\
(5.1) \\
\end{array}$ & $\begin{array}{c}58 \mathrm{abcd} \\
(3.4)\end{array}$ & $\begin{array}{l}95 \mathrm{bc} \\
(1.1) \\
\end{array}$ & $\begin{array}{l}87 \mathrm{bc} \\
(1.6) \\
\end{array}$ & $\begin{array}{c}\text { 54abd } \\
(3.6)\end{array}$ & $\begin{array}{c}\text { 90bcd } \\
(1.9)\end{array}$ \\
\hline $\begin{array}{r}100 \\
(0.0) \\
\end{array}$ & $100(0.0)$ & $\begin{array}{r}100 \\
(0.0) \\
\end{array}$ & $\begin{array}{r}100 \\
(0.0) \\
\end{array}$ & $\begin{array}{r}100 \\
(0.0) \\
\end{array}$ & $\begin{array}{r}100 \\
(0.0) \\
\end{array}$ & $\begin{array}{r}100 \\
(0.0) \\
\end{array}$ & $\begin{array}{r}100 \\
(0.0) \\
\end{array}$ & $\begin{array}{r}100 \\
(0.0) \\
\end{array}$ & $\begin{array}{r}100 \\
(0.0) \\
\end{array}$ & $\begin{array}{r}100 \\
(0.0) \\
\end{array}$ \\
\hline
\end{tabular}

${ }^{1}$ Percent frequency of sapling- and pole-sized aspen among eight site and environmental factors.

${ }^{2}$ During analysis, between 48-121 plots were excluded due to insufficient data or other problems, resulting in a sample size of 500 (for the percent mortality analysis) and 573 (for the percent live crown, regeneration occurrence, and disease and insect occurrence analyses).

*Some standard errors are very large due very low occurrence within some factor levels.

$* * \mathrm{BCH}=$ Brush Creek-Hayden ranger district

Significant differences between means are indicated by letters; means with different letters are significantly different from each other at the $\mathrm{P} \leq 0.05$ level. 
Table 4. Average incidence ${ }^{1}$ of insect- and disease damage among four size classes of aspen from a roadside survey, in Colorado, 2009 - 2010

\begin{tabular}{|c|c|c|c|c|}
\hline \multirow{3}{*}{ Independent Variable } & \multicolumn{2}{|c|}{ Insects } & \multicolumn{2}{|c|}{ Disease } \\
\hline & \multicolumn{4}{|c|}{$n=573^{2}$} \\
\hline & LS Mean & $\begin{array}{c}\text { Std } \\
\text { Error }\end{array}$ & LS Mean & $\begin{array}{c}\text { Std } \\
\text { Error }\end{array}$ \\
\hline \multicolumn{5}{|l|}{ Elevation } \\
\hline Low & 68 & 7.6 & 99 & 99.6 \\
\hline Moderate & 64 & 7.2 & 99 & 77.5 \\
\hline High & 60 & 9.2 & 99 & 87.8 \\
\hline \multicolumn{5}{|l|}{ Aspect } \\
\hline North & 63 & 7.8 & 99 & 8.3 \\
\hline East & 69 & 7.0 & 99 & 65.3 \\
\hline South & 63 & 7.5 & 99 & 98.3 \\
\hline West & 61 & 8.4 & 98 & 112.2 \\
\hline \multicolumn{5}{|l|}{ Slope Position } \\
\hline Summit- Shoulder Slope & 70 & 7.7 & 99 & 85.8 \\
\hline Backslope-Footslope & 64 & 6.5 & 98 & 149.9 \\
\hline Toeslope- Valley Bottom & 57 & 9.4 & 99 & 68.6 \\
\hline \multicolumn{5}{|l|}{ Slope Configuration } \\
\hline Broken & 83 & 15.8 & 100 & 0.0 \\
\hline Concave & 63 & 6.1 & 89 & 3.2 \\
\hline Convex & 59 & 5.7 & 85 & 4.4 \\
\hline Linear & 50 & 6.0 & 88 & 3.3 \\
\hline Undulating & 59 & 6.3 & 91 & 2.9 \\
\hline \multicolumn{5}{|l|}{ \% Slope } \\
\hline $0-9 \%$ & 66 & 7.5 & 99 & 65.7 \\
\hline $10-19 \%$ & 62 & 7.6 & 98 & 116.3 \\
\hline $20-29 \%$ & 65 & 7.8 & 98 & 135.8 \\
\hline $30-39 \%$ & 65 & 8.6 & 99 & 92.2 \\
\hline$\geq 40 \%$ & 62 & 9.5 & 99 & 54.3 \\
\hline \multicolumn{5}{|l|}{ Continental Divide } \\
\hline East & $79 \mathrm{~b}$ & 6.1 & 99 & 76.7 \\
\hline West & $44 \mathrm{a}$ & 7.1 & 99 & 100.5 \\
\hline \multicolumn{5}{|l|}{ Forest (Divide) } \\
\hline Medicine Bow & $88 \mathrm{c}$ & 6.6 & 99 & 47.9 \\
\hline Pike-San Isabel & $67 \mathrm{~b}$ & 6.5 & 98 & 122.4 \\
\hline Routt & $34 \mathrm{a}$ & 7.7 & 98 & 134.4 \\
\hline White River & $55 \mathrm{~b}$ & 7.4 & 99 & 75.0 \\
\hline \multicolumn{5}{|l|}{ District (Forest * Divide) } \\
\hline Brush Creek-Hayden & 89 & 11.1 & 99 & 46.7 \\
\hline Laramie & 87 & 5.1 & 99 & 49.0 \\
\hline Pike's Peak & 57 & 8.6 & 98 & 169.7 \\
\hline Salida & 66 & 9.8 & 98 & 172.5 \\
\hline San Carlos & 73 & 7.8 & 99 & 61.5 \\
\hline South Park & 72 & 10.1 & 98 & 123.8 \\
\hline Hahn's Peak & 29 & 8.4 & 98 & 107.2 \\
\hline Yampa & 41 & 9.7 & 98 & 168.2 \\
\hline Aspen-Sopris & 68 & 6.9 & 98 & 116.8 \\
\hline Blanco & 59 & 9.8 & 97 & 243.3 \\
\hline Rifle & 38 & 10.6 & 100 & 14.8 \\
\hline
\end{tabular}

${ }^{1}$ Average percent values are least-squares means of evidence of major insect or disease damage (e.g. wood borer symptoms, canker symptoms or decay fruiting bodies on stems) modeled with the eight site and environmental parameters. ${ }^{2}$ During analysis, between 48-121 plots were excluded due to insufficient data or other problems, resulting in a sample size of 500 (for the percent mortality analysis) and 573 (for the percent live crown, regeneration occurrence, and disease and insect occurrence analyses). Significant differences between means are indicated by letters; means with different letters are significantly different from each other at the $\mathrm{P} \leq 0.05$ level. 
Table 5. Average live aspen stems per hectare (stems/Ha) among four size classes in Aspen Stand Assessment Plots in Colorado, 2009 - 2010

\begin{tabular}{|c|c|c|c|c|c|c|c|c|}
\hline \multirow{3}{*}{ Parameter } & \multirow{2}{*}{\multicolumn{2}{|c|}{$\begin{array}{c}\text { Saplings } \\
\mathbf{n}=\mathbf{8 2}\end{array}$}} & \multirow{2}{*}{\multicolumn{2}{|c|}{$\begin{array}{c}\text { Small Pole } \\
n=62\end{array}$}} & \multirow{2}{*}{\multicolumn{2}{|c|}{$\begin{array}{c}\text { Large Pole } \\
n=70\end{array}$}} & \multicolumn{2}{|c|}{ Adults } \\
\hline & & & & & & & \multicolumn{2}{|c|}{$\mathrm{n}=92$} \\
\hline & $\begin{array}{c}\text { LS } \\
\text { Mean }\end{array}$ & $\begin{array}{c}\text { Std. } \\
\text { Error }\end{array}$ & $\begin{array}{c}\text { LS } \\
\text { Mean }\end{array}$ & $\begin{array}{c}\text { Std. } \\
\text { Error }\end{array}$ & $\begin{array}{c}\text { LS } \\
\text { Mean }\end{array}$ & $\begin{array}{c}\text { Std. } \\
\text { Error }\end{array}$ & $\begin{array}{c}\text { LS } \\
\text { Mean }\end{array}$ & $\begin{array}{c}\text { Std. } \\
\text { Error }\end{array}$ \\
\hline \multicolumn{9}{|l|}{ Elevation } \\
\hline Low & 1860 & 804.0 & 766 & 483.7 & 248 & 360.0 & 703 & 126.8 \\
\hline Moderate & 2294 & 664.1 & 1006 & 349.0 & 1032 & 271.2 & 767 & 100.9 \\
\hline High & 2995 & 950.4 & 1015 & 546.6 & 1044 & 387.4 & 693 & 155.0 \\
\hline \multicolumn{9}{|l|}{ Aspect } \\
\hline North & 1873 & 866.1 & $465 a$ & 539.8 & $586 \mathrm{ac}$ & 362.0 & 647 & 141.1 \\
\hline East & 3206 & 816.0 & $588 \mathrm{a}$ & 423.6 & $1405 d$ & 357.4 & 671 & 130.8 \\
\hline South & 2547 & 66.4 & $1618 b$ & 403.4 & 940acd & 301.8 & 709 & 104.1 \\
\hline West & 1907 & 921.1 & $1042 \mathrm{ab}$ & 456.5 & $165 a$ & 368.5 & 857 & 139.1 \\
\hline \multicolumn{9}{|l|}{ Stand Type } \\
\hline Damaged & 2550 & 721.3 & 997 & 390.6 & 645 & 288.0 & 655 & 108.9 \\
\hline Healthy & 2215 & 698.2 & 860 & 374.4 & 905 & 290.2 & 786 & 112.0 \\
\hline \multicolumn{9}{|l|}{ Divide Position } \\
\hline East & 2926 & 720.7 & 881 & 376.6 & $1151 b$ & 285.1 & 800 & 110.8 \\
\hline West & 1840 & 762.4 & 977 & 444.3 & $398 \mathrm{a}$ & 324.3 & 642 & 119.5 \\
\hline \multicolumn{9}{|l|}{ Forest (Divide) } \\
\hline Medicine Bow & 3959 & 994.8 & $1608 \mathrm{~d}$ & 594.8 & $2178 b$ & 433.0 & 944 & 157.2 \\
\hline Pike-San Isabel & 1894 & 723.1 & $152 \mathrm{ab}$ & 412.1 & $123 a$ & 294.9 & 656 & 115.2 \\
\hline Routt & 2244 & 959.3 & $1534 \mathrm{~cd}$ & 603.2 & $153 a$ & 433.2 & 683 & 146.7 \\
\hline White River & 1436 & 795.0 & $420 \mathrm{ab}$ & 428.9 & $643 a$ & 346.1 & 600 & 122.9 \\
\hline \multicolumn{9}{|l|}{ Slope Position } \\
\hline Summit - Shoulder & 1765 & 1041.3 & 560 & 660.0 & 545 & 505.2 & 587 & 140.6 \\
\hline Backslope - Footslope & 2933 & 588.0 & 1176 & 268.2 & 1031 & 217.9 & 819 & 85.8 \\
\hline Toeslope - Valley & 2450 & 923.1 & 1051 & 514.4 & 747 & 373.5 & 757 & 140.6 \\
\hline \multicolumn{9}{|l|}{ \% Slope } \\
\hline $0-9 \%$ & 1751 & 792.4 & 589 & 461.7 & 640 & 351.3 & 666 & 123.4 \\
\hline $10-19 \%$ & 2138 & 723.4 & 743 & 404.4 & 790 & 300.2 & 721 & 114.0 \\
\hline $20-29 \%$ & 3262 & 793.7 & 1380 & 467.9 & 1445 & 364.1 & 615 & 124.3 \\
\hline $30-39 \%$ & 2649 & 1058.1 & 554 & 570.4 & 328 & 428.4 & 893 & 162.9 \\
\hline$\geq 40 \%$ & 2114 & 1070.4 & 1378 & 603.3 & 670 & 464.6 & 709 & 167.9 \\
\hline \multicolumn{9}{|l|}{ Slope Configuration } \\
\hline Concave & 2534 & 698.3 & 1607 & 521.6 & 243 & 775.9 & $442 a$ & 116.4 \\
\hline Convex & 1521 & 607.2 & 1068 & 375.9 & 539 & 357.3 & $588 \mathrm{a}$ & 97.9 \\
\hline Linear & 4042 & 749.7 & 950 & 454.1 & 1249 & 313.0 & $978 \mathrm{c}$ & 140.8 \\
\hline Broken & 1861 & 2340.0 & 209 & 984.6 & 243 & 776.0 & $947 a b c$ & 317.7 \\
\hline Undulating & 1957 & 675.4 & 810 & 418.8 & 654 & 305.1 & $647 b$ & 110.0 \\
\hline \multicolumn{9}{|l|}{ Age } \\
\hline & $\begin{array}{c}\text { Paramete } \\
\text { r Est }\end{array}$ & Std. Err & $\begin{array}{c}\text { Paramete } \\
\text { r Est }\end{array}$ & $\begin{array}{l}\text { Std. } \\
\text { Err }\end{array}$ & $\begin{array}{c}\text { Paramete } \\
\text { r Est }\end{array}$ & Std. Err & $\begin{array}{c}\text { Paramete } \\
\text { r Est }\end{array}$ & $\begin{array}{l}\text { Std. } \\
\text { Err }\end{array}$ \\
\hline & 40.08 & 205.220 & -13.58 & $\begin{array}{r}19.65 \\
7 \\
\end{array}$ & 3.45 & 12.481 & 2.82 & 2.040 \\
\hline
\end{tabular}

Average stems per hectare are least-squares means as modeled with the eight site and environmental parameters.

Significant differences between means are indicated by letters; means with different letters are significantly different from each other at the $\mathrm{P} \leq 0.05$ level. $\mathrm{N}=$ the number of transects with size classes present.

Saplings were stems $0.3-1.37 \mathrm{~m}$ tall; small poles were those with DBH $0.1-2.9 \mathrm{~cm}$; large poles were those with DBH $3.0-11.9 \mathrm{~cm}$; adults were those with $\mathrm{DBH}>11.9 \mathrm{~cm}$. 
Table 6. Quadratic Mean Diameter (QMD) among three size classes of aspen, from Aspen Stand Assessment Plots in Colorado, 2009 - 2010

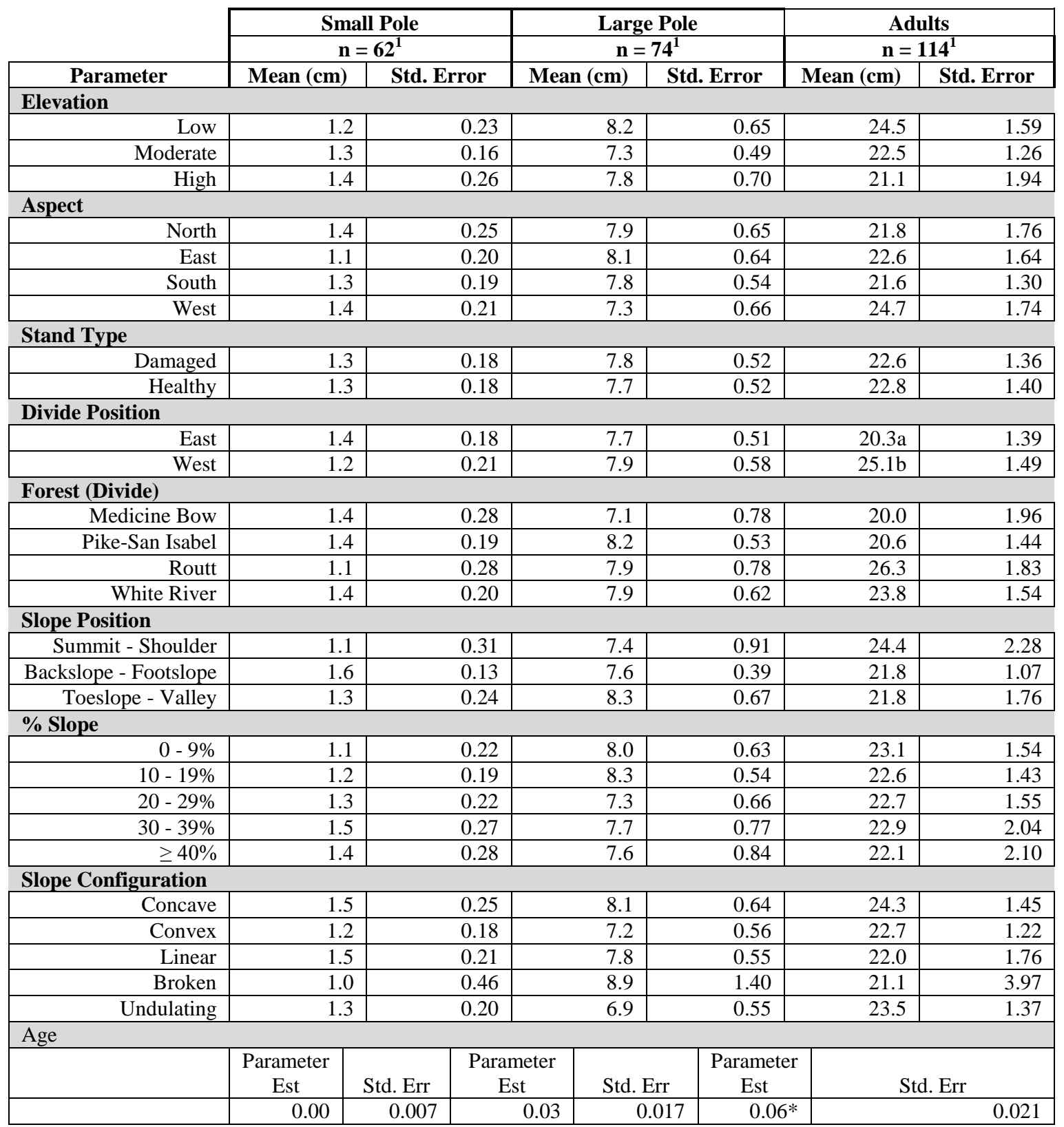

Quadratic Mean Diameters are least-squares means as modeled with the eight site and environmental parameters. QMD was calculated using equation 2 in the appendix.

${ }^{1}$ Sample size (n) is the number of trees averaged by ranger district, stand type, transect, and size class.

Significant differences between means are indicated by letters; means with different letters are significantly different from each other at the $\mathrm{P} \leq 0.05$ level.

*Indicates significance at the $\mathrm{P} \leq 0.05$ level.

Saplings were stems $0.3-1.37 \mathrm{~m}$ tall; small poles were those with DBH $0.1-2.9 \mathrm{~cm}$; large poles were those with DBH $3.0-11.9 \mathrm{~cm}$; adults were those with DBH $>11.9 \mathrm{~cm}$. 
Table 7. Average percent of live aspen stems among four size classes, in Aspen Stand Assessment Plots, 2009 - 2010

\begin{tabular}{|c|c|c|c|c|c|c|c|c|}
\hline \multirow[b]{2}{*}{ Parameter } & \multicolumn{2}{|c|}{$\begin{array}{c}\text { Saplings } \\
\mathbf{n}=\mathbf{8 3}^{1}\end{array}$} & \multicolumn{2}{|c|}{$\begin{array}{c}\text { Small Pole } \\
n=62^{1}\end{array}$} & \multicolumn{2}{|c|}{$\begin{array}{c}\text { Large Pole } \\
\mathrm{n}=74^{1} \\
\end{array}$} & \multicolumn{2}{|c|}{$\begin{array}{c}\text { Adults } \\
\mathrm{n}=114^{1}\end{array}$} \\
\hline & $\begin{array}{c}\text { LS Mean } \\
(\%)\end{array}$ & $\begin{array}{c}\text { Std. } \\
\text { Error }\end{array}$ & $\begin{array}{c}\text { LS Mean } \\
(\%)\end{array}$ & $\begin{array}{c}\text { Std. } \\
\text { Error }\end{array}$ & $\begin{array}{c}\text { LS Mean } \\
(\%)\end{array}$ & $\begin{array}{c}\text { Std. } \\
\text { Error }\end{array}$ & $\begin{array}{c}\text { LS } \\
\text { Mean } \\
(\%)\end{array}$ & $\begin{array}{c}\text { Std. } \\
\text { Error }\end{array}$ \\
\hline \multicolumn{9}{|l|}{ Elevation } \\
\hline Low & 78 & 13.1 & 71 & 20.0 & 71 & 15.8 & 75 & 6.2 \\
\hline Moderate & 93 & 10.8 & 63 & 14.5 & 82 & 11.9 & 77 & 4.9 \\
\hline High & 94 & 15.5 & 51 & 22.7 & 64 & 17.0 & 83 & 7.6 \\
\hline \multicolumn{9}{|l|}{ Aspect } \\
\hline North & 95 & 14.1 & 41 & 22.4 & 53 & 15.8 & 84 & 6.9 \\
\hline East & 94 & 13.3 & 48 & 17.6 & 87 & 15.6 & 82 & 6.4 \\
\hline South & 76 & 10.9 & 76 & 16.8 & 78 & 13.2 & 81 & 5.1 \\
\hline West & 87 & 15.0 & 82 & 19.0 & 72 & 16.1 & 67 & 6.8 \\
\hline \multicolumn{9}{|l|}{ Stand Type } \\
\hline Damaged & 95 & 11.8 & 59 & 16.2 & $60 a$ & 12.6 & $70 a$ & 5.3 \\
\hline Healthy & 81 & 11.4 & 65 & 15.6 & $84 \mathrm{~b}$ & 12.7 & $86 b$ & 5.5 \\
\hline \multicolumn{9}{|l|}{ Divide Position } \\
\hline East & 94 & 11.8 & 55 & 15.6 & 77 & 12.5 & 75 & 5.4 \\
\hline West & 82 & 12.4 & 68 & 18.5 & 67 & 14.2 & 81 & 5.9 \\
\hline \multicolumn{9}{|l|}{ Forest (Divide) } \\
\hline Medicine Bow & 115 & 16.2 & 69 & 25.0 & 81 & 18.9 & 77 & 7.7 \\
\hline Pike-San Isabel & 78 & 11.8 & 42 & 17.1 & 74 & 12.9 & 74 & 5.6 \\
\hline Routt & 78 & 15.6 & 67 & 25.1 & 62 & 19.0 & 78 & 7.2 \\
\hline White River & 86 & 13.0 & 69 & 17.8 & 72 & 15.1 & 85 & 6.0 \\
\hline \multicolumn{9}{|l|}{ Slope Position } \\
\hline Summit - Shoulder & 77 & 17.0 & 65 & 27.4 & 78 & 22.1 & 84 & 8.9 \\
\hline $\begin{array}{l}\text { Backslope - } \\
\text { Footslope }\end{array}$ & 91 & 9.6 & 56 & 11.1 & 55 & 9.5 & 74 & 4.2 \\
\hline Toeslope - Valley & 96 & 15.0 & 64 & 21.4 & 83 & 16.3 & 76 & 6.9 \\
\hline \multicolumn{9}{|l|}{ \% Slope } \\
\hline $0-9 \%$ & 77 & 12.9 & 78 & 19.2 & 74 & 15.4 & 67 & 6.0 \\
\hline $10-19 \%$ & 79 & 11.8 & 76 & 16.8 & 62 & 13.1 & 81 & 5.6 \\
\hline $20-29 \%$ & 103 & 12.9 & 51 & 19.4 & 55 & 15.9 & 82 & 6.1 \\
\hline $30-39 \%$ & 107 & 17.3 & 35 & 23.7 & 72 & 18.7 & 85 & 8.0 \\
\hline$\geq 40 \%$ & 74 & 17.5 & 69 & 25.1 & 99 & 20.3 & 77 & 8.2 \\
\hline \multicolumn{9}{|l|}{ Slope Configuration } \\
\hline Concave & 91 & 11.4 & 86 & 21.7 & 72 & 15.6 & 80 & 5.7 \\
\hline Convex & 80 & 9.9 & 74 & 15.6 & 79 & 13.7 & 74 & 4.8 \\
\hline Linear & 91 & 12.2 & 42 & 18.9 & 69 & 13.4 & 87 & 6.9 \\
\hline Broken & 98 & 38.0 & 50 & 40.9 & 59 & 34.0 & 71 & 15.6 \\
\hline Undulating & 81 & 11.0 & 56 & 17.4 & 82 & 13.4 & 80 & 5.4 \\
\hline \multicolumn{9}{|l|}{ Age } \\
\hline & $\begin{array}{l}\text { Parameter } \\
\text { Est }\end{array}$ & Std. Err & $\begin{array}{l}\text { Parameter } \\
\text { Est }\end{array}$ & $\begin{array}{l}\text { Std. } \\
\text { Err }\end{array}$ & $\begin{array}{l}\text { Parameter } \\
\text { Est }\end{array}$ & Std. Err & $\begin{array}{c}\text { Parameter } \\
\text { Est }\end{array}$ & Std. Err \\
\hline & 0.00 & 0.016 & $-0.01 *$ & 0.005 & $-0.01 *$ & 0.003 & $0.00^{*}$ & 0.001 \\
\hline
\end{tabular}

Average percent values are least-squares means as modeled with the eight site and environmental parameters.

${ }^{1}$ Sample size (n) is the number of trees averaged by ranger district, stand type, transect, and size class.

Significant differences between means are indicated by letters; means with different letters are significantly different from each other at the $\mathrm{P} \leq 0.05$ level.

*Indicates significance at the $\mathrm{P} \leq 0.05$ level.

Saplings were stems $0.3-1.37 \mathrm{~m}$ tall; small poles were those with DBH $0.1-2.9 \mathrm{~cm}$; large poles were those with DBH $3.0-11.9 \mathrm{~cm}$; adults were those with DBH $>11.9 \mathrm{~cm}$. 
Table 8. Average health status of four size classes of aspen in Aspen Stand Assessment Plots in Colorado, 2009 - 2010

\begin{tabular}{|c|c|c|c|c|c|c|c|c|}
\hline \multirow[b]{4}{*}{ Parameter } & \multicolumn{8}{|c|}{ Average Health Status } \\
\hline & \multirow{2}{*}{\multicolumn{2}{|c|}{$\begin{array}{c}\text { Saplings } \\
\mathbf{n}=\mathbf{8 3}^{1}\end{array}$}} & \multirow{2}{*}{\multicolumn{2}{|c|}{$\begin{array}{c}\text { Small Pole } \\
n=62^{1}\end{array}$}} & \multirow{2}{*}{\multicolumn{2}{|c|}{$\begin{array}{c}\text { Large Pole } \\
n=74^{1}\end{array}$}} & \multirow{2}{*}{\multicolumn{2}{|c|}{$\begin{array}{c}\text { Adults } \\
\mathrm{n}=114^{1}\end{array}$}} \\
\hline & & & & & & & & \\
\hline & $\begin{array}{c}\text { LS } \\
\text { Mean }\end{array}$ & $\begin{array}{l}\text { Std. } \\
\text { Error }\end{array}$ & $\begin{array}{c}\text { LS } \\
\text { Mean }\end{array}$ & $\begin{array}{c}\text { Std. } \\
\text { Error }\end{array}$ & $\begin{array}{c}\text { LS } \\
\text { Mean }\end{array}$ & $\begin{array}{c}\text { Std. } \\
\text { Error }\end{array}$ & $\begin{array}{c}\text { LS } \\
\text { Mean }\end{array}$ & $\begin{array}{c}\text { Std. } \\
\text { Error }\end{array}$ \\
\hline \multicolumn{9}{|l|}{ Elevation } \\
\hline Low & 2.0 & 0.26 & $1.4 \mathrm{a}$ & 0.49 & $2.2 \mathrm{ab}$ & 0.45 & 2.1 & 0.19 \\
\hline Moderate & 1.9 & 0.21 & $2.4 \mathrm{a}$ & 0.35 & $1.6 \mathrm{a}$ & 0.34 & 2.1 & 0.15 \\
\hline High & 1.9 & 0.30 & $3.3 \mathrm{~b}$ & 0.55 & $2.6 \mathrm{~b}$ & 0.49 & 1.8 & 0.24 \\
\hline \multicolumn{9}{|l|}{ Aspect } \\
\hline North & 1.8 & 0.28 & 2.9 & 0.55 & 2.2 & 0.46 & $1.8 \mathrm{a}$ & 0.22 \\
\hline East & 2.0 & 0.26 & 2.6 & 0.43 & 2.0 & 0.45 & $1.9 \mathrm{ab}$ & 0.20 \\
\hline South & 2.1 & 0.21 & 1.9 & 0.41 & 2.0 & 0.38 & $1.9 \mathrm{ab}$ & 0.16 \\
\hline West & 1.9 & 0.29 & 2.1 & 0.46 & 2.3 & 0.46 & $2.4 \mathrm{~b}$ & 0.21 \\
\hline \multicolumn{9}{|l|}{ Stand Type } \\
\hline Damaged & $1.7 \mathrm{a}$ & 0.23 & 2.4 & 0.40 & 2.3 & 0.36 & $2.3 b$ & 0.17 \\
\hline Healthy & $2.2 \mathrm{~b}$ & 0.22 & 2.4 & 0.38 & 2.0 & 0.37 & $1.7 \mathrm{a}$ & 0.17 \\
\hline \multicolumn{9}{|l|}{$\begin{array}{l}\text { Continental Divide } \\
\text { Position }\end{array}$} \\
\hline East & 1.8 & 0.23 & 2.6 & 0.38 & 2.1 & 0.36 & 2.1 & 0.17 \\
\hline West & 2.0 & 0.24 & 2.2 & 0.45 & 2.1 & 0.41 & 1.8 & 0.18 \\
\hline \multicolumn{9}{|l|}{ Forest (Divide) } \\
\hline Medicine Bow & $1.4 \mathrm{a}$ & 0.32 & 2.5 & 0.60 & 1.8 & 0.54 & 2.1 & 0.24 \\
\hline Pike-San Isabel & $2.2 b$ & 0.23 & 2.7 & 0.42 & 2.5 & 0.37 & 2.2 & 0.18 \\
\hline Routt & $2.3 b$ & 0.30 & 1.9 & 0.61 & 2.2 & 0.55 & 1.9 & 0.22 \\
\hline White River & $1.8 \mathrm{ab}$ & 0.25 & 2.5 & 0.44 & 2.1 & 0.44 & 1.8 & 0.19 \\
\hline \multicolumn{9}{|l|}{ Slope Position } \\
\hline Summit - Shoulder & 2.3 & 0.33 & 2.5 & 0.67 & 2.0 & 0.64 & 1.8 & 0.28 \\
\hline Backslope - & & & & & & & & \\
\hline Footslope & 1.7 & 0.19 & 2.5 & 0.27 & 2.5 & 0.27 & 2.0 & 0.13 \\
\hline Toeslope - Valley & 1.8 & 0.29 & 2.1 & 0.52 & 1.9 & 0.47 & 2.1 & 0.22 \\
\hline \multicolumn{9}{|l|}{ \% Slope } \\
\hline $0-9 \%$ & 1.8 & 0.25 & $1.8 \mathrm{a}$ & 0.47 & 2.0 & 0.44 & 2.2 & 0.19 \\
\hline $10-19 \%$ & 1.9 & 0.23 & $2.5 \mathrm{ab}$ & 0.41 & 2.6 & 0.38 & 1.9 & 0.17 \\
\hline $20-29 \%$ & 1.7 & 0.25 & $2.6 \mathrm{ab}$ & 0.47 & 2.1 & 0.46 & 2.1 & 0.19 \\
\hline $30-39 \%$ & 1.7 & 0.34 & $3.3 b$ & 0.58 & 2.1 & 0.54 & 1.7 & 0.25 \\
\hline$\geq 40 \%$ & 2.5 & 0.34 & $1.7 \mathrm{a}$ & 0.61 & 1.9 & 0.58 & 2.0 & 0.26 \\
\hline \multicolumn{9}{|l|}{ Slope Configuration } \\
\hline Concave & 1.9 & 0.22 & 1.8 & 0.53 & 2.2 & 0.45 & 2.0 & 0.18 \\
\hline Convex & 2.2 & 0.19 & 2.2 & 0.38 & 2.1 & 0.39 & 2.2 & 0.15 \\
\hline Linear & 2.1 & 0.24 & 3.2 & 0.46 & 2.6 & 0.39 & 1.7 & 0.22 \\
\hline Broken & 1.3 & 0.74 & 2.2 & 1.00 & 2.1 & 0.98 & 2.1 & 0.49 \\
\hline Undulating & 2.2 & 0.21 & 2.5 & 0.43 & 1.7 & 0.38 & 2.0 & 0.17 \\
\hline \multicolumn{9}{|l|}{ Age* } \\
\hline \multirow[t]{2}{*}{ Parameter Est } & $\begin{array}{l}\text { Std. } \\
\text { Err }\end{array}$ & $\begin{array}{c}\text { Paramet } \\
\text { er Est }\end{array}$ & $\begin{array}{l}\text { Std. } \\
\text { Err }\end{array}$ & $\begin{array}{l}\text { Paramet } \\
\text { er Est }\end{array}$ & $\begin{array}{l}\text { Std. } \\
\text { Err }\end{array}$ & $\begin{array}{l}\text { Parameter } \\
\text { Est }\end{array}$ & $\begin{array}{l}\text { Std. } \\
\text { Err }\end{array}$ & $\begin{array}{c}\text { Paramet } \\
\text { er Est }\end{array}$ \\
\hline & -0.03 & 0.053 & 0.03 & 0.016 & .03 & 0.011 & 0.11 & 0.095 \\
\hline
\end{tabular}

Health status is based on a 5-point index, where $1=$ healthy, $2=5-50 \%$ damaged, $3=>50 \%$ damage, $4=$ recent mortality $(<5$ years since death), $5=$ old mortality $(>5$ years since death). Average health status is least-squares means as modeled with the eight site and environmental parameters.

${ }^{1}$ Sample size (n) is the number of trees averaged by ranger district, stand type, transect, and size class.

*Age means are parameter estimates. Significant differences between means are indicated by letters; means with different letters are significantly different from each other at the $\mathrm{P} \leq 0.05$ level.

Saplings were stems $0.3-1.37 \mathrm{~m}$ tall; small poles were those with DBH $0.1-2.9 \mathrm{~cm}$; large poles were those with DBH 3.0 - $11.9 \mathrm{~cm}$; adults were those with DBH $>11.9 \mathrm{~cm}$. 
Table 9. Average percent live crown of adult aspen in Aspen Stand

Assessment Plots in Colorado, 2009 -

2010

\begin{tabular}{|c|c|c|}
\hline $\mathrm{n}=116^{1}$ & \multicolumn{2}{|c|}{ Adults } \\
\hline Parameter & Mean & Std. Error \\
\hline \multicolumn{3}{|l|}{ Elevation } \\
\hline Low & $75 \mathrm{ab}$ & 6.0 \\
\hline Moderate & $67 a$ & 4.8 \\
\hline High & $80 \mathrm{~b}$ & 7.3 \\
\hline \multicolumn{3}{|l|}{ Aspect } \\
\hline North & 77 & 6.7 \\
\hline East & 78 & 6.2 \\
\hline South & 76 & 4.9 \\
\hline West & 65 & 6.6 \\
\hline \multicolumn{3}{|l|}{ Stand Type } \\
\hline Damaged & $62 a$ & 5.2 \\
\hline Healthy & $86 b$ & 5.3 \\
\hline \multicolumn{3}{|l|}{ Divide Position } \\
\hline East & 70 & 5.2 \\
\hline West & 78 & 5.7 \\
\hline \multicolumn{3}{|l|}{ Forest (Divide) } \\
\hline Medicine Bow & 65 & 7.4 \\
\hline Pike-San Isabel & 76 & 6.9 \\
\hline Routt & 77 & 6.9 \\
\hline White River & 78 & 5.8 \\
\hline \multicolumn{3}{|l|}{ Slope Position } \\
\hline Summit - Shoulder & 83 & 6.6 \\
\hline Backslope - Footslope & 70 & 4.1 \\
\hline Toeslope - Valley & 69 & 6.7 \\
\hline \multicolumn{3}{|l|}{ \% Slope } \\
\hline $0-9 \%$ & $65 a$ & 5.8 \\
\hline $10-19 \%$ & $77 \mathrm{bc}$ & 5.4 \\
\hline $20-29 \%$ & $70 \mathrm{ab}$ & 5.9 \\
\hline $30-39 \%$ & $87 \mathrm{c}$ & 7.7 \\
\hline$\geq 40 \%$ & $71 \mathrm{ab}$ & 7.9 \\
\hline \multicolumn{3}{|l|}{ Slope Configuration } \\
\hline Concave & 71 & 5.5 \\
\hline Convex & 68 & 4.6 \\
\hline Linear & 81 & 6.7 \\
\hline Broken & 78 & 15.0 \\
\hline Undulating & 72 & 5.2 \\
\hline \multicolumn{3}{|l|}{ Age* $^{*}$} \\
\hline & $\begin{array}{c}\text { Parameter } \\
\text { Est }\end{array}$ & Std. Err \\
\hline & -0.018 & 0.0005 \\
\hline
\end{tabular}

Least-squares means are the average adult percent live crown as modeled with the eight site and environmental parameters.

${ }^{1}$ Sample size (n) is the number of trees averaged by ranger district, stand type, transect, and size class.

*Age mean is a parameter estimate, and represents the relationship of regeneration age to average percent live crown of adult aspen.

Significant differences between means are indicated by letters; means with different letters are significantly different from each other at the $\mathrm{P} \leq 0.05$ level. 
Table 10. Percent incidence of canker diseases on four size classes of live aspen in Aspen Stand Assessment Plots in Colorado, 2009 - 2010

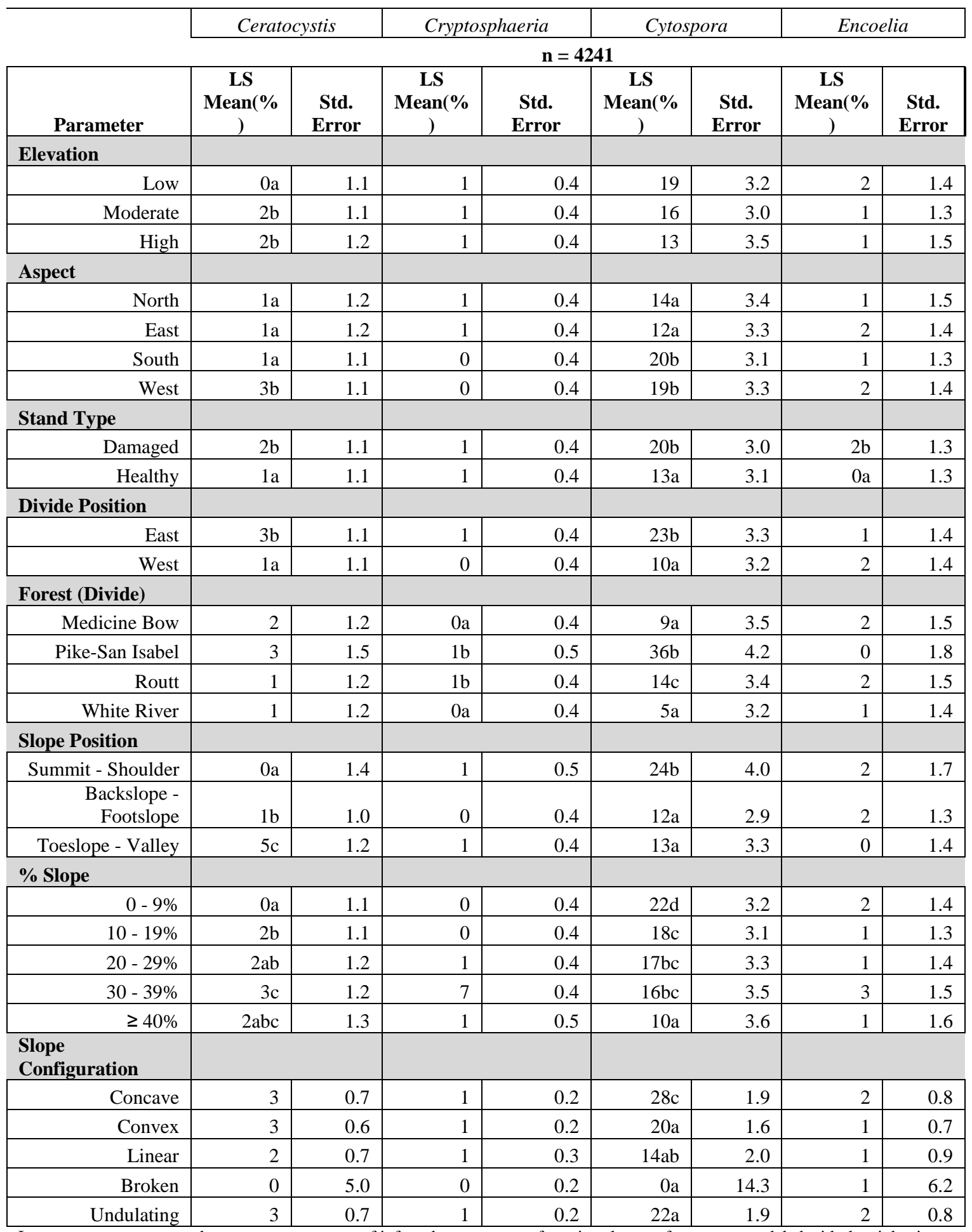

Least-squares means are the average percentage of infested stems among four size classes of aspen, as modeled with the eight site and environmental parameters.

Significant differences between means are indicated by letters; means with different letters are significantly different from each other at the $\mathrm{P} \leq 0.05$ level

Saplings were stems $0.3-1.37 \mathrm{~m}$ tall; small poles were those with DBH $0.1-2.9 \mathrm{~cm}$; large poles were those with DBH $3.0-11.9$ $\mathrm{cm}$; adults were those with $\mathrm{DBH}>11.9 \mathrm{~cm}$. 
Table 11. Percent incidence of decay and foliar blights among four size classes of live aspen in Aspen Stand Assessment Plots in Colorado, 2009 2010

\begin{tabular}{|c|c|c|c|c|c|c|}
\hline \multirow{4}{*}{$\begin{array}{c} \\
\text { Parameter } \\
\text { Elevation }\end{array}$} & \multicolumn{2}{|c|}{ Phellinus tremula } & \multicolumn{2}{|c|}{ Marssonina Populi } & \multicolumn{2}{|c|}{ Venturia tremulae } \\
\hline & \multicolumn{6}{|c|}{$n=4241$} \\
\hline & $\begin{array}{c}\text { LS } \\
\text { Mean }(\%)\end{array}$ & $\begin{array}{c}\text { Std. } \\
\text { Error }\end{array}$ & $\begin{array}{c}\text { LS } \\
\operatorname{Mean}(\%)\end{array}$ & $\begin{array}{r}\text { Std. } \\
\text { Error }\end{array}$ & $\begin{array}{c}\mathrm{LS} \\
\operatorname{Mean}(\%)\end{array}$ & $\begin{array}{c}\text { Std. } \\
\text { Error }\end{array}$ \\
\hline & & & & & & \\
\hline Low & $4 \mathrm{~b}$ & 1.8 & $15 \mathrm{c}$ & 2.9 & 2 & 1.1 \\
\hline Moderate & $4 \mathrm{~b}$ & 1.7 & $11 \mathrm{~b}$ & 2.8 & 1 & 1.0 \\
\hline High & $0 \mathrm{a}$ & 2.0 & $8 a$ & 3.2 & 2 & 1.2 \\
\hline Aspect & & & & & & \\
\hline North & $4 \mathrm{~b}$ & 1.9 & $15 b$ & 3.1 & $3 b$ & 1.2 \\
\hline East & $2 a b$ & 1.8 & $6 a$ & 3.0 & $1 \mathrm{a}$ & 1.1 \\
\hline South & $1 \mathrm{a}$ & 1.7 & $9 a$ & 2.8 & $1 \mathrm{a}$ & 1.1 \\
\hline West & $3 \mathrm{bc}$ & 1.8 & $14 \mathrm{~b}$ & 2.9 & $1 \mathrm{a}$ & 1.1 \\
\hline Stand Type & & & & & & \\
\hline Damaged & 3 & 1.7 & $13 a$ & 2.8 & 1 & 1.0 \\
\hline Healthy & 2 & 1.8 & $9 \mathrm{~b}$ & 2.8 & 2 & 1.1 \\
\hline Divide Position & & & & & & \\
\hline East & $1 \mathrm{a}$ & 1.8 & $3 a$ & 2.9 & 1 & 1.1 \\
\hline West & $4 \mathrm{~b}$ & 1.8 & $19 b$ & 2.9 & 2 & 1.1 \\
\hline Forest (Divide) & & & & & & \\
\hline Medicine Bow & $0 \mathrm{a}$ & 2.0 & $2 \mathrm{a}$ & 3.2 & 2 & 1.2 \\
\hline Pike-San Isabel & $4 \mathrm{~b}$ & 2.3 & $5 \mathrm{a}$ & 3.8 & 0 & 1.4 \\
\hline Routt & $5 b$ & 1.9 & $26 c$ & 3.1 & 1 & 1.2 \\
\hline White River & $4 \mathrm{~b}$ & 1.8 & $13 b$ & 2.9 & 3 & 1.1 \\
\hline Slope Position & & & & & & \\
\hline Summit - Shoulder & 2 & 2.2 & 10 & 3.6 & 1 & 1.3 \\
\hline $\begin{array}{l}\text { Backslope - } \\
\text { Footslope }\end{array}$ & 3 & 1.6 & 11 & 2.6 & 2 & 1.0 \\
\hline Toeslope - Valley & 2 & 1.8 & 12 & 3.0 & 2 & 1.1 \\
\hline \% Slope & & & & & & \\
\hline $0-9 \%$ & 4 & 1.8 & $12 \mathrm{bc}$ & 2.9 & $0 \mathrm{a}$ & 1.1 \\
\hline $10-19 \%$ & 4 & 1.7 & $11 \mathrm{~b}$ & 2.8 & $1 b$ & 1.1 \\
\hline $20-29 \%$ & 2 & 1.9 & $5 a$ & 3.0 & $3 c$ & 1.1 \\
\hline $30-39 \%$ & 2 & 1.9 & $16 \mathrm{c}$ & 3.1 & $1 b$ & 1.2 \\
\hline$\geq 40 \%$ & 1 & 2.0 & $11 \mathrm{~b}$ & 3.3 & $3 \mathrm{c}$ & 1.2 \\
\hline $\begin{array}{l}\text { Slope } \\
\text { Configuration }\end{array}$ & & & & & & \\
\hline Concave & $4 \mathrm{bc}$ & 1.0 & $18 \mathrm{bc}$ & 1.7 & 1 & 4.8 \\
\hline Convex & $3 b$ & 0.9 & $12 \mathrm{bc}$ & 1.5 & 2 & 0.6 \\
\hline Linear & $2 \mathrm{a}$ & 1.1 & 10ad & 1.8 & 1 & 0.5 \\
\hline Broken & $0 \mathrm{abc}$ & 8.0 & $13 \mathrm{abcd}$ & 12.9 & 2 & 0.7 \\
\hline Undulating & $5 c$ & 1.1 & $4 \mathrm{a}$ & 1.7 & 3 & 0.6 \\
\hline
\end{tabular}

Least-squares means are the average percentage of infested stems among four size classes of aspen, as modeled with the eight site and environmental parameters.

Significant differences between means are indicated by letters; means with different letters are significantly different from each other at the $\mathrm{P} \leq 0.05$ level 
Table 12. Percent incidence of insect damage among four size classes of aspen in Aspen Stand Assessment Plots in Colorado, 2009 - 2010

\begin{tabular}{|c|c|c|c|c|c|c|c|c|}
\hline \multirow[b]{3}{*}{ Parameter } & \multicolumn{2}{|c|}{ Wood Borers } & \multicolumn{2}{|c|}{ Bark Beetles } & \multicolumn{2}{|c|}{ Foliage Feeders } & \multicolumn{2}{|c|}{ Leaf Tiers } \\
\hline & \multicolumn{8}{|c|}{$n=4241$} \\
\hline & LS Mean(\%) & $\begin{array}{l}\text { Std. } \\
\text { Error }\end{array}$ & $\begin{array}{c}\text { LS } \\
\text { Mean( } \% \\
)\end{array}$ & $\begin{array}{l}\text { Std. } \\
\text { Error }\end{array}$ & $\begin{array}{c}\text { LS } \\
\text { Mean }(\% \\
)\end{array}$ & $\begin{array}{c}\text { Std. } \\
\text { Error }\end{array}$ & $\begin{array}{c}\mathbf{L S} \\
\operatorname{Mean}(\%)\end{array}$ & $\begin{array}{c}\text { Std. } \\
\text { Erro } \\
r\end{array}$ \\
\hline \multicolumn{9}{|l|}{ Elevation } \\
\hline Low & $13 a$ & 3.4 & $18 \mathrm{c}$ & 2.4 & $1 \mathrm{a}$ & 1.0 & $1 \mathrm{a}$ & $1.1 \%$ \\
\hline Moderate & $21 \mathrm{bc}$ & 3.2 & $11 \mathrm{~b}$ & 2.2 & $3 b$ & 0.9 & $3 b$ & $1.0 \%$ \\
\hline High & $20 \mathrm{bc}$ & 3.7 & $6 \mathrm{a}$ & 2.6 & $0 \mathrm{a}$ & 1.0 & $2 \mathrm{ab}$ & $1.2 \%$ \\
\hline \multicolumn{9}{|l|}{ Aspect } \\
\hline North & 18 & 3.6 & $16 \mathrm{c}$ & 2.5 & $2 b$ & 1.0 & $2 \mathrm{ab}$ & $1.2 \%$ \\
\hline East & 18 & 3.4 & $5 a$ & 2.4 & $3 c$ & 1.0 & $1 \mathrm{a}$ & $1.4 \%$ \\
\hline South & 20 & 3.3 & $14 \mathrm{c}$ & 2.3 & $0 \mathrm{a}$ & 0.9 & $1 \mathrm{~b}$ & $1.2 \%$ \\
\hline West & 18 & 3.4 & $10 \mathrm{~b}$ & 2.4 & $1 \mathrm{~b}$ & 1.0 & $3 b$ & $1.0 \%$ \\
\hline \multicolumn{9}{|l|}{ Stand Type } \\
\hline Damaged & $27 \mathrm{~b}$ & 3.2 & $16 \mathrm{~b}$ & 2.4 & $3 b$ & 0.9 & $3 b$ & $1.1 \%$ \\
\hline Healthy & $10 \mathrm{a}$ & 3.3 & $7 \mathrm{a}$ & 2.3 & $0 \mathrm{a}$ & 0.9 & $1 \mathrm{a}$ & $1.1 \%$ \\
\hline \multicolumn{9}{|l|}{ Divide Position } \\
\hline East & $22 b$ & 3.4 & $15 b$ & 2.4 & $0 \mathrm{a}$ & 1.0 & 2 & $1.1 \%$ \\
\hline West & $14 \mathrm{a}$ & 3.3 & $8 \mathrm{a}$ & 2.3 & $2 b$ & 0.9 & 2 & $1.1 \%$ \\
\hline \multicolumn{9}{|l|}{ Forest (Divide) } \\
\hline Medicine Bow & 21 & 3.6 & $0 \mathrm{a}$ & 2.6 & 0 & 1.0 & $2 \mathrm{ab}$ & $1.2 \%$ \\
\hline Pike-San Isabel & 24 & 4.4 & $41 d$ & 3.0 & 0 & 1.2 & $1 \mathrm{ab}$ & $1.4 \%$ \\
\hline Routt & 12 & 3.6 & $10 \mathrm{c}$ & 2.5 & 3 & 1.0 & $1 \mathrm{a}$ & $1.2 \%$ \\
\hline White River & 16 & 3.4 & $5 b$ & 2.4 & 2 & 0.9 & $3 b$ & $1.1 \%$ \\
\hline \multicolumn{9}{|l|}{ Slope Position } \\
\hline $\begin{array}{l}\text { Summit - } \\
\text { Shoulder }\end{array}$ & 18 & 4.1 & $19 b$ & 2.9 & 1 & 1.2 & $4 \mathrm{~b}$ & 1.4 \\
\hline $\begin{array}{l}\text { Backslope - } \\
\text { Footslope }\end{array}$ & 17 & 3.1 & $9 \mathrm{a}$ & 2.1 & 1 & 0.9 & $1 \mathrm{a}$ & 1.0 \\
\hline $\begin{array}{r}\text { Toeslope - } \\
\text { Valley }\end{array}$ & 20 & 3.4 & $7 \mathrm{a}$ & 2.4 & 1 & 1.0 & $2 \mathrm{ab}$ & 1.1 \\
\hline \multicolumn{9}{|l|}{ \% Slope } \\
\hline $0-9 \%$ & $13 a$ & 3.4 & $18 \mathrm{c}$ & 2.4 & $1 b$ & 1.0 & 1 & 1.1 \\
\hline $10-19 \%$ & $17 \mathrm{bc}$ & 3.3 & $13 b$ & 2.3 & $4 c$ & 0.9 & 2 & 1.1 \\
\hline $20-29 \%$ & $21 \mathrm{bc}$ & 3.5 & $9 \mathrm{a}$ & 2.4 & $0 \mathrm{a}$ & 1.0 & 3 & 1.1 \\
\hline $30-39 \%$ & $16 a c$ & 3.6 & $8 \mathrm{a}$ & 2.5 & $0 \mathrm{a}$ & 1.0 & 2 & 1.2 \\
\hline$\geq 40 \%$ & $24 d$ & 3.8 & $9 \mathrm{a}$ & 2.6 & $1 b$ & 1.1 & 3 & 1.2 \\
\hline \multicolumn{9}{|l|}{$\begin{array}{l}\text { Slope } \\
\text { Configuration }\end{array}$} \\
\hline Concave & $22 b$ & 2.0 & $21 b$ & 1.4 & $0 \mathrm{a}$ & 4.2 & $2 a$ & 0.6 \\
\hline Convex & $21 b c$ & 1.7 & $18 \mathrm{bc}$ & 1.1 & $2 c$ & 0.5 & $2 a$ & 0.6 \\
\hline Linear & $16 \mathrm{a}$ & 2.1 & $9 \mathrm{a}$ & 1.5 & $1 \mathrm{a}$ & 0.6 & $2 a$ & 0.7 \\
\hline Broken & $6 a b c$ & 15.0 & $0 \mathrm{a}$ & 10.5 & $3 a b c$ & 4.2 & $0 \mathrm{a}$ & 4.9 \\
\hline Undulating & $26 c$ & 2.0 & $16 \mathrm{c}$ & 1.4 & $0 \mathrm{~b}$ & 0.6 & $4 \mathrm{~b}$ & 0.6 \\
\hline
\end{tabular}

Least-square means are percent occurrence of insect presence among four size classes of aspen analyzed with eight site and environmental parameters.

Significant differences between means are indicated by letters; means with different letters are significantly different from each other at the $\mathrm{P} \leq 0.05$ level.

Saplings were stems $0.3-1.37 \mathrm{~m}$ tall; small poles were those with DBH $0.1-2.9 \mathrm{~cm}$; large poles were those with DBH $3.0-11.9 \mathrm{~cm}$; adults were those with DBH $>11.9 \mathrm{~cm}$. 
Table 13. Incidence of wounding, galls, and browsing among four size classes of aspen in Aspen Stand Assessment Plots in Colorado, 2009 - 2010

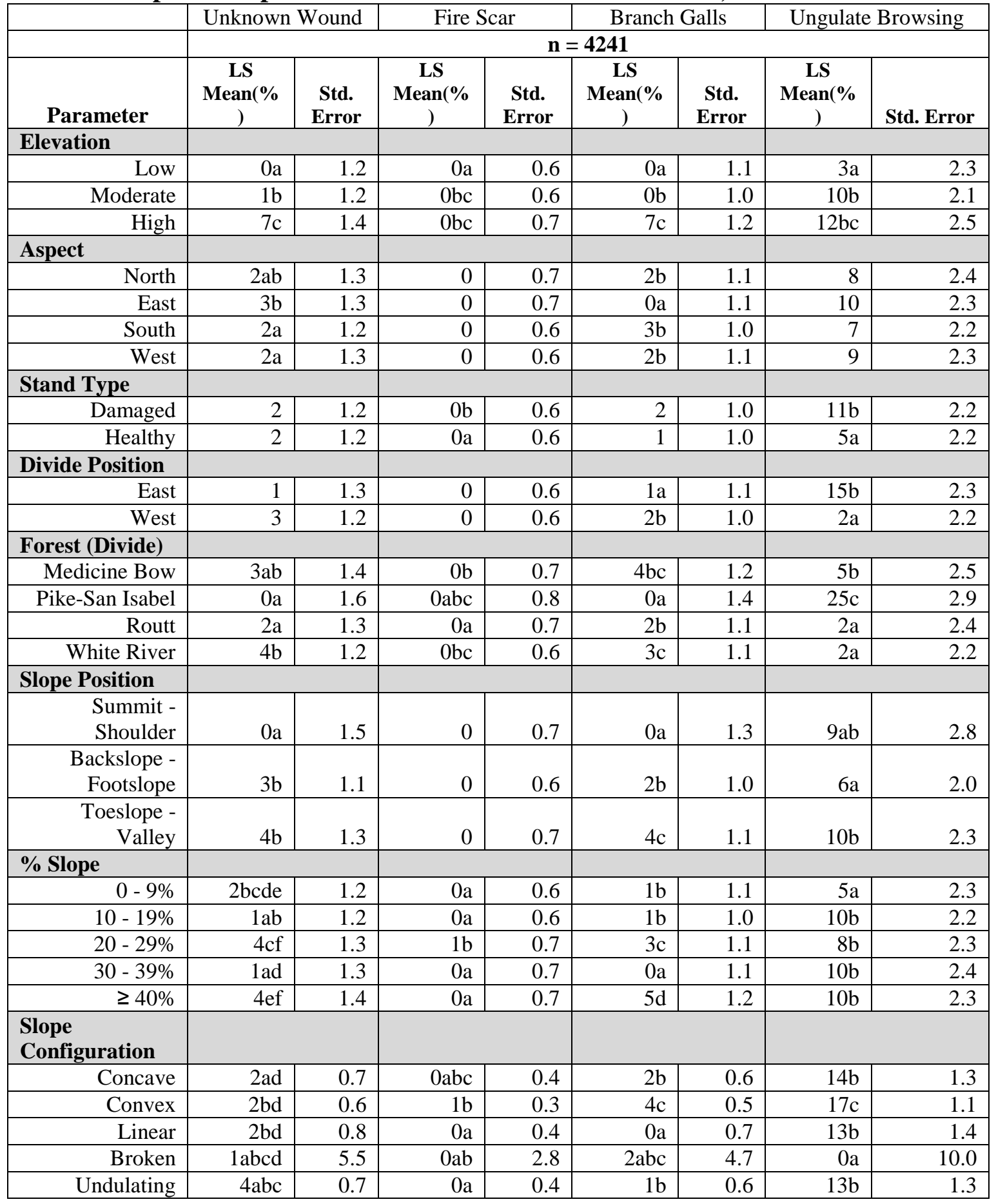

Least-square means are percent occurrence of insect presence among four size classes of aspen analyzed with eight site and environmental parameters.

Significant differences between means are indicated by letters; means with different letters are significantly different from each other at the $\mathrm{P} \leq 0.05$ level.

Saplings were stems $0.3-1.37 \mathrm{~m}$ tall; small poles were those with DBH $0.1-2.9 \mathrm{~cm}$; large poles were those with DBH $3.0-11.9 \mathrm{~cm}$; adults were those with DBH $>11.9 \mathrm{~cm}$. 
Table 14. Severity of Cytospora canker, Phellinus decay, and Marssonina foliar blight among four size classes of aspen in Aspen Stand Assessment Plots in Colorado, 2009 - 2010

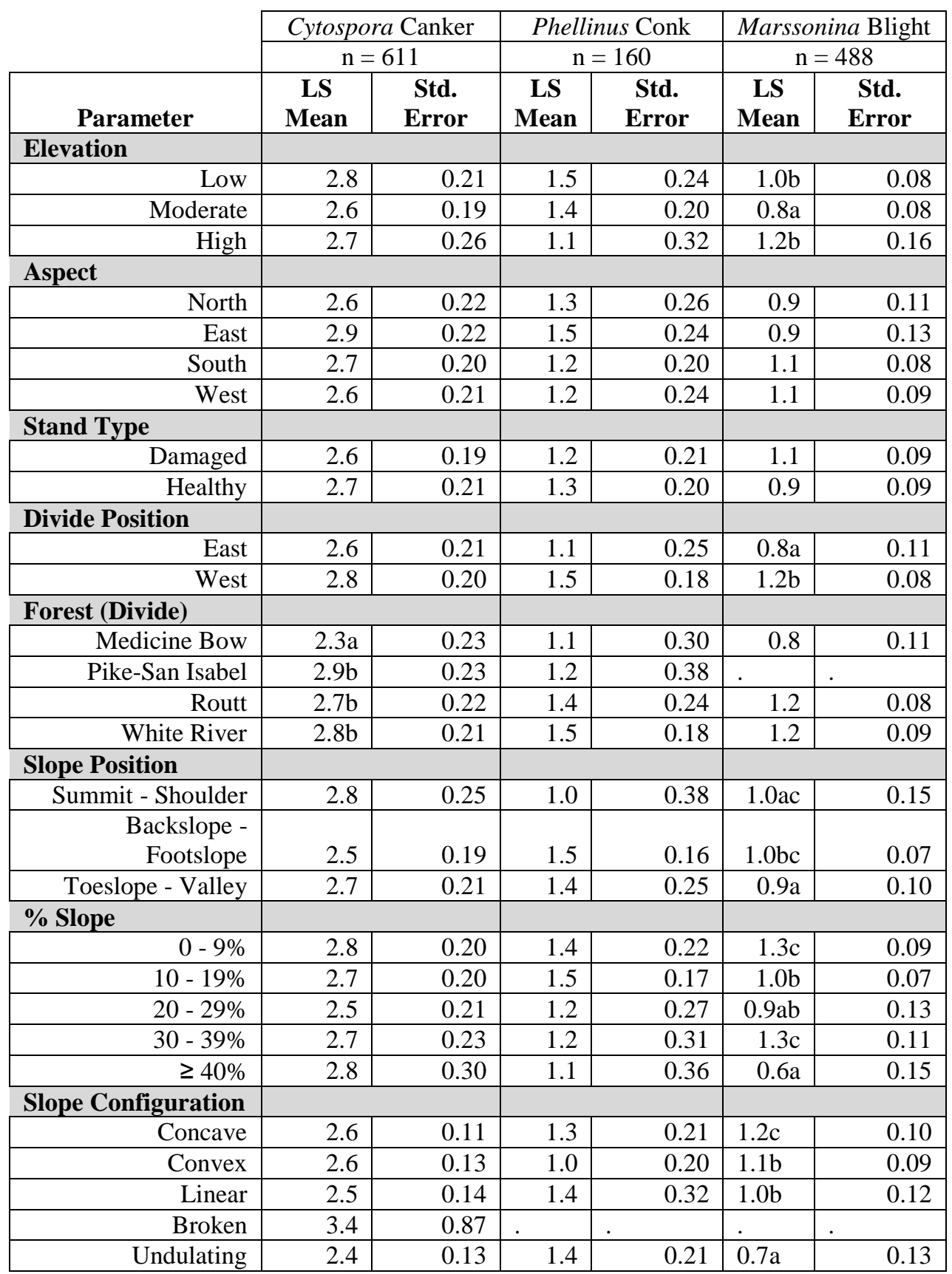

Least-square means are severity $(1-3)$ of each disease among four size classes of aspen analyzed with eight site and environmental parameters.

Significant differences between means are indicated by letters; means with different letters are significantly different from each other at the $\mathrm{P} \leq 0.05$ level.

Saplings were stems $0.3-1.37 \mathrm{~m}$ tall; small poles were those with DBH $0.1-2.9 \mathrm{~cm}$; large poles were those with DBH $3.0-11.9 \mathrm{~cm}$; adults were those with $\mathrm{DBH}>11.9 \mathrm{~cm}$. 
Table 15. Average ages of four size classes of aspen in the Aspen Stand Assessment Survey in Colorado, 2009 - 2010

\begin{tabular}{|c|c|c|c|c|c|c|c|c|}
\hline \multirow[b]{2}{*}{ Parameter } & \multicolumn{2}{|c|}{$\begin{array}{c}\text { Saplings } \\
\mathrm{n}=\mathbf{7 3}\end{array}$} & \multicolumn{2}{|c|}{$\begin{array}{c}\text { Small Poles } \\
\mathbf{n}=\mathbf{3 6}\end{array}$} & \multicolumn{2}{|c|}{$\begin{array}{c}\text { Large Poles } \\
n=41\end{array}$} & \multicolumn{2}{|c|}{$\begin{array}{l}\text { Adults } \\
\mathrm{n}=83\end{array}$} \\
\hline & $\begin{array}{c}\text { LSMean, } \\
\text { Years }\end{array}$ & $\begin{array}{c}\text { Std. } \\
\text { Error }\end{array}$ & $\begin{array}{l}\text { LSMean, } \\
\text { Years }\end{array}$ & $\begin{array}{c}\text { Std. } \\
\text { Error }\end{array}$ & $\begin{array}{c}\text { LSMean, } \\
\text { Years }\end{array}$ & $\begin{array}{c}\text { Std. } \\
\text { Error }\end{array}$ & $\begin{array}{c}\text { LSMean, } \\
\text { Years }\end{array}$ & $\begin{array}{c}\text { Std. } \\
\text { Error }\end{array}$ \\
\hline \multicolumn{9}{|l|}{$\begin{array}{l}\text { Divide } \\
\text { Position }\end{array}$} \\
\hline East & 5 & 0.4 & 34 & 6.5 & 35 & 8.3 & 87 & 4.5 \\
\hline West & 6 & 0.5 & 23 & 3.2 & 28 & 3.5 & 95 & 4.7 \\
\hline \multicolumn{9}{|l|}{ Stand Type } \\
\hline Damaged & 5 & 0.4 & 27 & 4.4 & 28 & 5.6 & 95 & 4.6 \\
\hline Healthy & 5 & 0.4 & 30 & 4.0 & 34 & 4.8 & 88 & 4.5 \\
\hline \multicolumn{9}{|l|}{$\begin{array}{l}\text { Forest } \\
\text { (Divide) }\end{array}$} \\
\hline $\begin{array}{l}\text { Medicine } \\
\text { Bow }\end{array}$ & 4 & 0.7 & 36 & 12.7 & 35 & 16.2 & 78 & 7.1 \\
\hline $\begin{array}{l}\text { Pike-San } \\
\text { Isabel }\end{array}$ & 5 & 0.5 & 32 & 3.0 & 35 & 3.7 & 96 & 5.4 \\
\hline Routt & 6 & 0.7 & 29 & 5.1 & 35 & 5.1 & 97 & 7.4 \\
\hline White River & 5 & 0.6 & 17.3 & 3.8 & 21 & 5.0 & 93 & 5.9 \\
\hline
\end{tabular}

Least-squares means are average ages of four size classes of aspen analyzed with three site parameters. Saplings were stems $0.3-1.37 \mathrm{~m}$ tall; small poles were those with DBH $0.1-2.9 \mathrm{~cm}$; large poles were those with DBH 3.0 - $11.9 \mathrm{~cm}$; adults were those with DBH $>11.9 \mathrm{~cm}$. 
Table 16. List of all disease and damage agents included in the Aspen Stand Assessment Survey in Colorado, 2009 - 2010

\begin{tabular}{|c|c|}
\hline Damage Agent Code & Agent Description \\
\hline 1.10 & Wood Borers \\
\hline 1.20 & Bark Beetles \\
\hline 1.21 & Ambrosia Beetles \\
\hline 1.22 & Bronze Poplar Borer \\
\hline 1.23 & Poplar Borer \\
\hline 1.30 & Foliage Feeders \\
\hline 1.31 & Large Aspen Tortrix \\
\hline 1.32 & Forest Tent Caterpillar \\
\hline 1.33 & Aspen Leafminer \\
\hline 1.34 & Aspen Blotchminer \\
\hline 1.35 & 5 Sawflies \\
\hline 1.36 & 6Lafhoppers \\
\hline 1.37 & 7 Eriophyid mites \\
\hline 1.38 & Unknown chewing \\
\hline 1.39 & Blotchminer \\
\hline 1.40 & Leaf Tier \\
\hline 1.50 & Leaf Roller \\
\hline 1.80 & Aphids \\
\hline 2.00 & Fungal Agents \\
\hline 2.11 & Cytospora, unknown \\
\hline 2.11 .1 & Cytospora, C. chrysosperma \\
\hline 2.11 .2 & Cytospora, other \\
\hline 2.12 & 2 Cryptosphaeria lignyota \\
\hline 2.13 & Black Canker-Ceratocystis fimbriata \\
\hline 2.14 & Sooty Bark-Encoelia pruinosa \\
\hline 2.20 & Decay fungi- trunk \\
\hline 2.21 & 1 Phellinus tremula \\
\hline 2.22 & Peniophora polygonia \\
\hline 2.30 & Decay fungi- roots \\
\hline 2.31 & Armillaria spp. \\
\hline 2.32 & Ganoderma applanatum \\
\hline 2.40 & Foliar Fungi \\
\hline 2.41 & Ink spot- Ciborinia spp. \\
\hline 2.42 & Shepherd's Crook-Venturia moreletii \\
\hline 2.43 & 3 Marssonina populi \\
\hline 2.44 & Melampsora medusae \\
\hline 2.47 & 7 Dothiora polyspora \\
\hline 3.00 & Animal Damage \\
\hline 3.10 & Animal feeding-bark \\
\hline 3.12 & Animal feeding- stems \\
\hline 3.13 & 3 Antler Rubbing \\
\hline 3.20 & Moose feeding \\
\hline 3.30 & Rodent feeding-bark \\
\hline 3.31 & Rodent feeding- stems \\
\hline 3.40 & Porcupine feeding \\
\hline 3.50 & Beavers feeding-bark \\
\hline 3.51 & Beavers feeding-stems/twig \\
\hline 3.52 & Beavers-structural \\
\hline 3.60 & Birds-feeding \\
\hline 3.61 & Birds-cavity nesting \\
\hline 3.70 & Humans \\
\hline 4.00 & Abiotic \\
\hline 4.10 & Lightning \\
\hline 4.20 & Sunscald \\
\hline 4.30 & Apparent drought stress \\
\hline 4.40 & Frost crack \\
\hline 4.50 & Fire scar \\
\hline 4.60 & Unknown wound \\
\hline 4.70 & Branch gall \\
\hline
\end{tabular}


Table 17. Percentage of established transects where Armillaria root rot was discovered on dead and live aspen in Aspen Stand Assessment plots in Colorado, 2009 - 2010

\begin{tabular}{|c|c|c|}
\hline \multirow[b]{3}{*}{ Total } & \multicolumn{2}{|c|}{$\begin{array}{c}\text { Percent Transects with } \\
\text { Armillaria }\end{array}$} \\
\hline & Dead aspen & Live aspen \\
\hline & 63.9 & 11.3 \\
\hline \multicolumn{3}{|l|}{ Forest } \\
\hline \multirow{4}{*}{$\begin{array}{l}\text { Pike-San Isabel } \\
\text { Medicine Bow } \\
\text { Routt } \\
\text { White River }\end{array}$} & 51.4 & 2.6 \\
\hline & 58.8 & 11.8 \\
\hline & 62.5 & 12.5 \\
\hline & 57.6 & 3.8 \\
\hline \multicolumn{3}{|l|}{ Stand Type } \\
\hline \multirow{2}{*}{$\begin{array}{l}\text { Damaged } \\
\text { Healthy }\end{array}$} & 47.1 & 14.3 \\
\hline & 52.8 & 8.0 \\
\hline \multicolumn{3}{|l|}{ Divide Position } \\
\hline \multirow{2}{*}{$\begin{array}{l}\text { East } \\
\text { West }\end{array}$} & 53.8 & 50.0 \\
\hline & 59.5 & 50.0 \\
\hline
\end{tabular}


Table 18. Total hectares of aspen coverage $^{1}$ within the four national forests and eleven ranger districts included in this survey

\begin{tabular}{|c|c|c|c|}
\hline Forest & R.D. & Ha & $\begin{array}{l}\text { Pet } \\
\text { Total }\end{array}$ \\
\hline \multicolumn{2}{|c|}{ Medicine Bow } & \multicolumn{2}{|l|}{25874} \\
\hline & $\begin{array}{l}\text { Brush Crk- } \\
\text { Hayden }\end{array}$ & 20987 & 81.1 \\
\hline & Laramie & 1414 & 5.5 \\
\hline & Douglas & 3474 & 13.4 \\
\hline \multirow[t]{3}{*}{ Routt } & \multicolumn{3}{|c|}{113120} \\
\hline & Yampa & 42370 & 37.5 \\
\hline & Hahn's Pk & 70750 & 62.5 \\
\hline \multicolumn{2}{|c|}{ White River } & \multicolumn{2}{|l|}{136446} \\
\hline & Blanco & 45788 & 33.6 \\
\hline & Aspen-Sopris & 67486 & 49.5 \\
\hline & Rifle & 23172 & 17.0 \\
\hline \multicolumn{2}{|c|}{ Pike-San Isabel } & \multicolumn{2}{|l|}{123441} \\
\hline & Pike's Pk & 5570 & 4.5 \\
\hline & S. Platte & 8894 & 7.2 \\
\hline & S. Park & 31180 & 25.3 \\
\hline & Salida & 27324 & 22.1 \\
\hline & San Carlos & 50472 & 40.9 \\
\hline
\end{tabular}

\footnotetext{
${ }^{\mathrm{T}}$ Area calculation of aspen covertype based on remotely-sensed vegetation data for Colorado, courtesy the Colorado Vegetation Classification Project.
} 
Table 19. Total hectares of remotely-sensed and mapped aspen damage ${ }^{1}$ and percent annual change of aspen damage area within the four national forests for the years $2006-2009$

\begin{tabular}{|c|c|c|c|c|}
\hline Forest & 2006 & 2007 & 2008 & 2009 \\
\hline Medicine Bow Damage (ha) & 3422 & 1978 & 805 & 648 \\
\hline Pct of Cover & 13.2 & 7.6 & 3.1 & 2.5 \\
\hline Pct Change & - & -5.6 & -4.5 & -0.6 \\
\hline Routt Damage (ha) & 5740 & 15190 & 14793 & 9569 \\
\hline Pct of Cover & 5.1 & 13.4 & 13.1 & 8.5 \\
\hline Pct Change & - & 8.4 & -0.4 & -4.6 \\
\hline White River Damage (ha) & 5528 & 18253 & 22608 & 20007 \\
\hline Pct of Cover & 4.1 & 13.4 & 16.6 & 14.7 \\
\hline Pct Change & - & 9.3 & 3.2 & -1.9 \\
\hline Pike-San Isabel Damage (ha) & 1104 & 10682 & 2593 & 5754 \\
\hline Pct of Cover & 0.01 & 0.1 & 0.01 & 0.1 \\
\hline Pct Change & - & 7.8 & -6.6 & 2.6 \\
\hline \multirow{3}{*}{$\begin{array}{r}\text { Total per Year } \\
\text { Pct Cover } \\
\text { Pct Change }\end{array}$} & 15794 & 46103 & 40799 & 35978 \\
\hline & 4.0 & 11.6 & 10.2 & 9.0 \\
\hline & 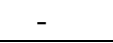 & 0.1 & -0.01 & -0.01 \\
\hline
\end{tabular}

${ }^{1}$ Area of annual aspen damage calculated based on aspen damage shapefiles, courtesy the U.S. Forest Service Region 2 Forest Health Protection. Areas mapped indicated thin crowns, dead standing aspen, or both. 


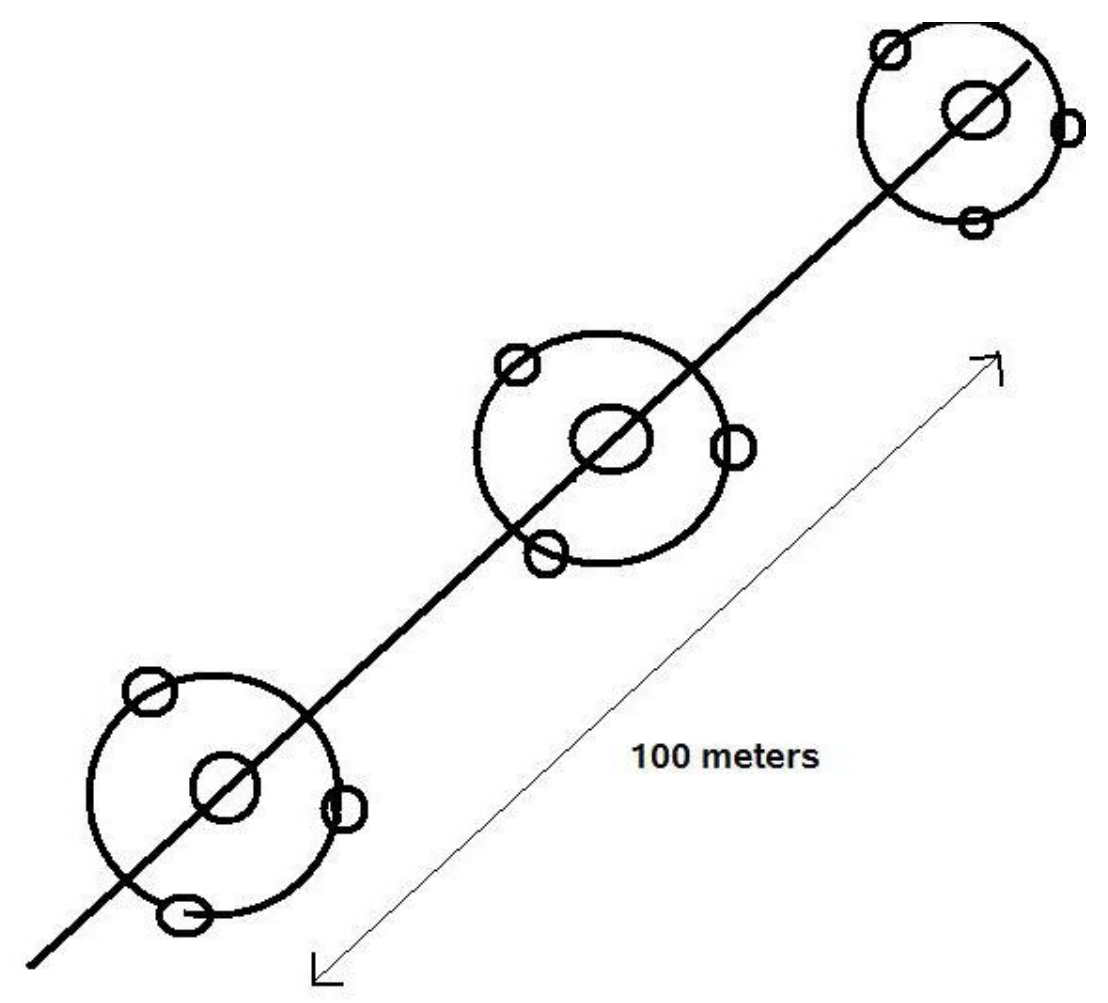

Figure 1. Diagram of 100-m transect and fixed-area circular plots utilized in aspen stand assessment plots in Colorado, 2009-2010. 


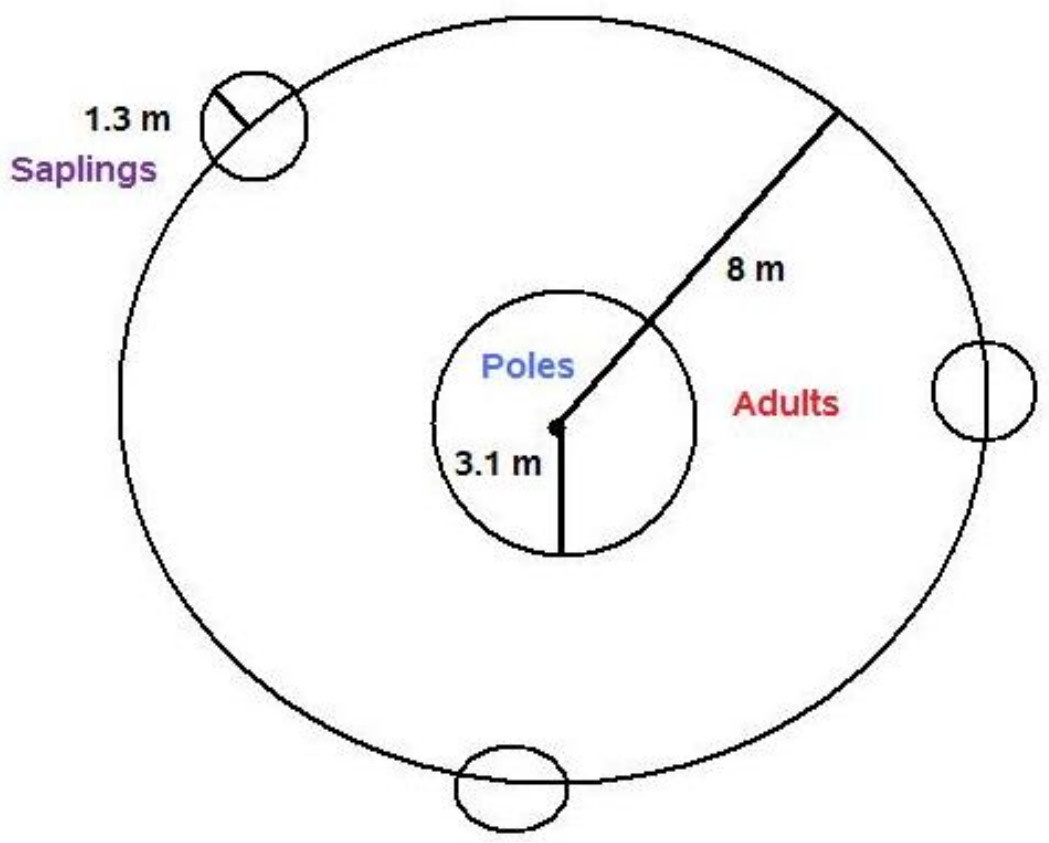

Figure 2. Detail of the fixed-area circular plot type utilized in aspen stand assessment plots in Colorado, 2009-2010. 


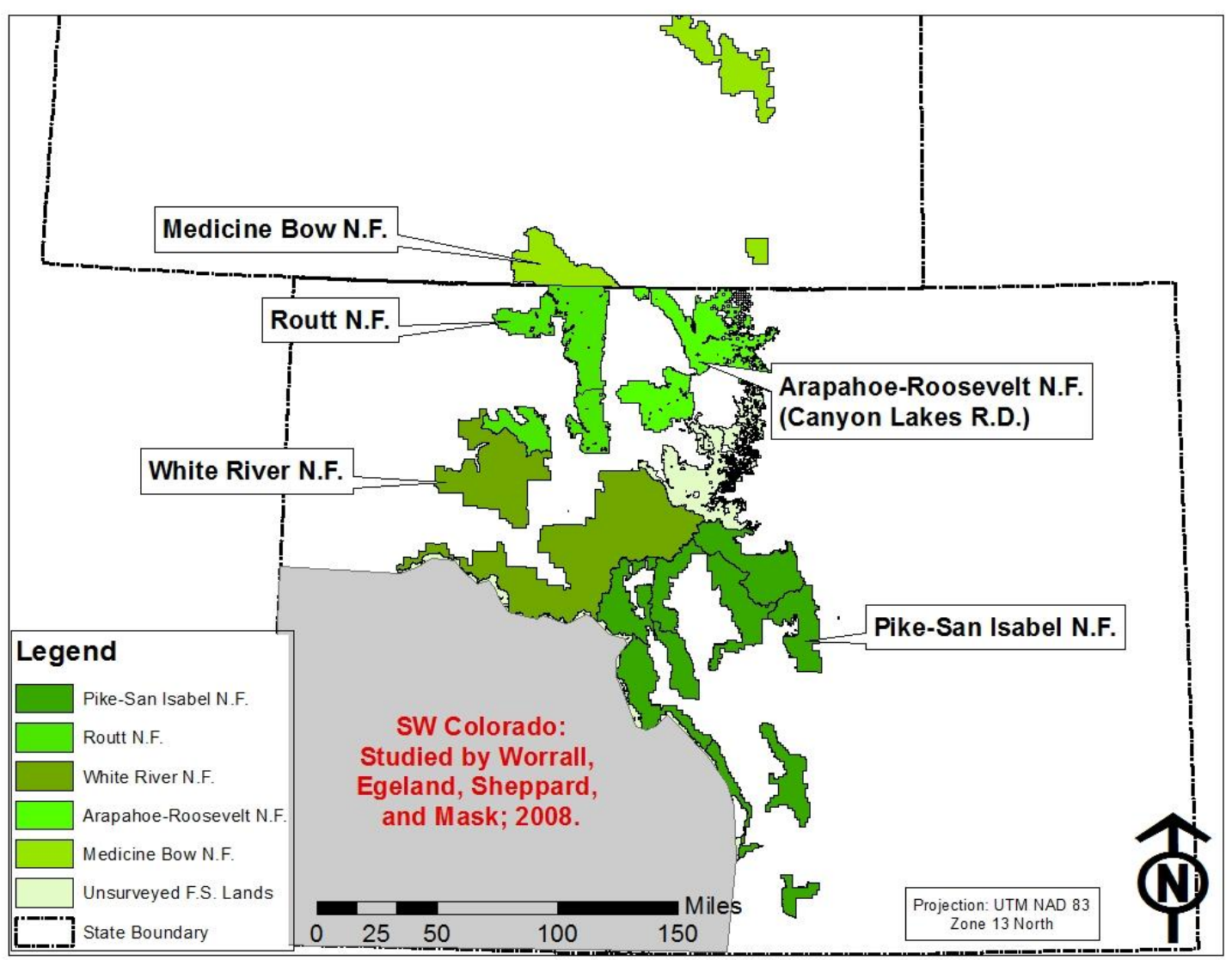

Fig. 3. Map of the National Forests surveyed in aspen stand assessment survey in Colorado, 2009-2010. 


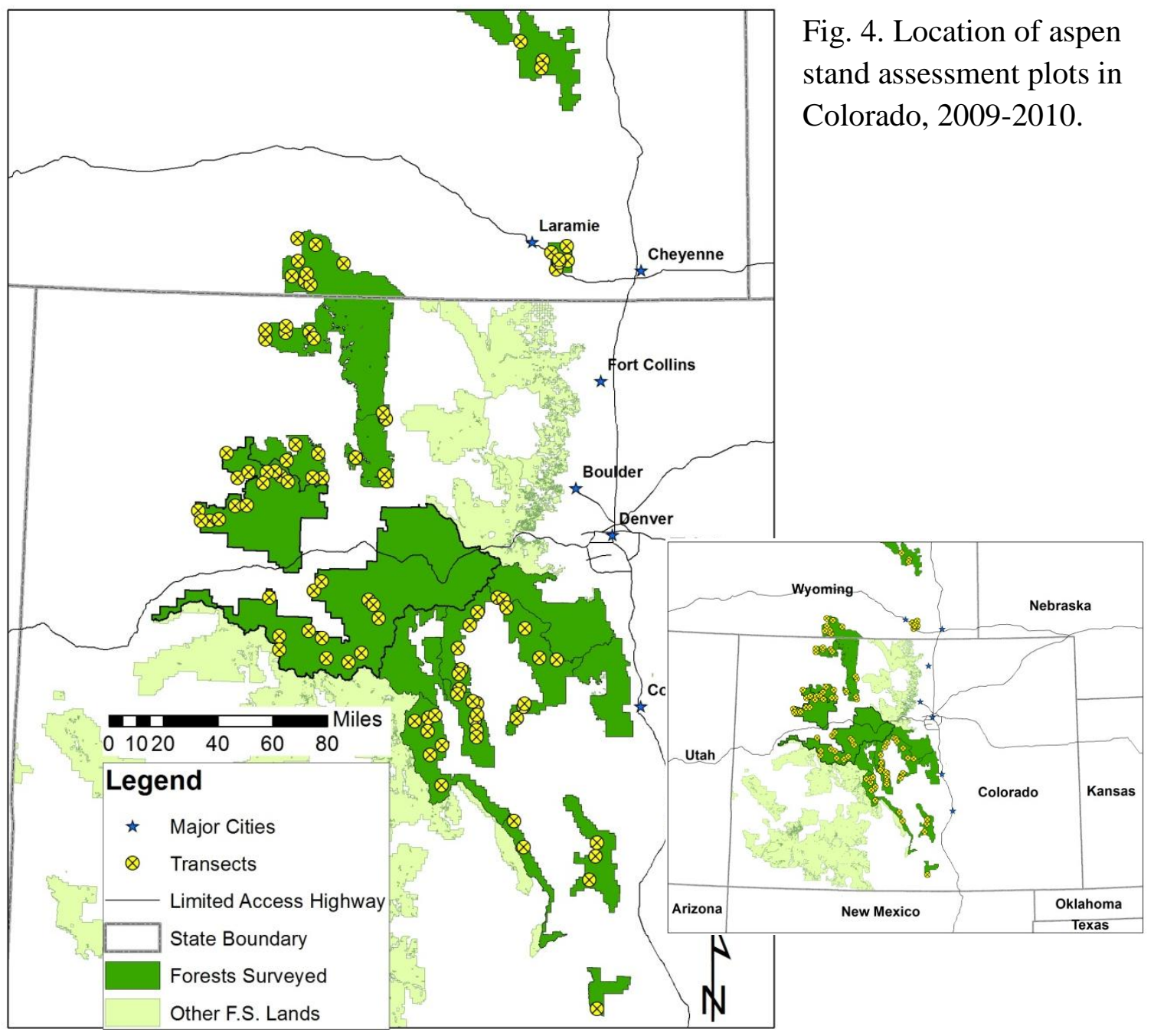




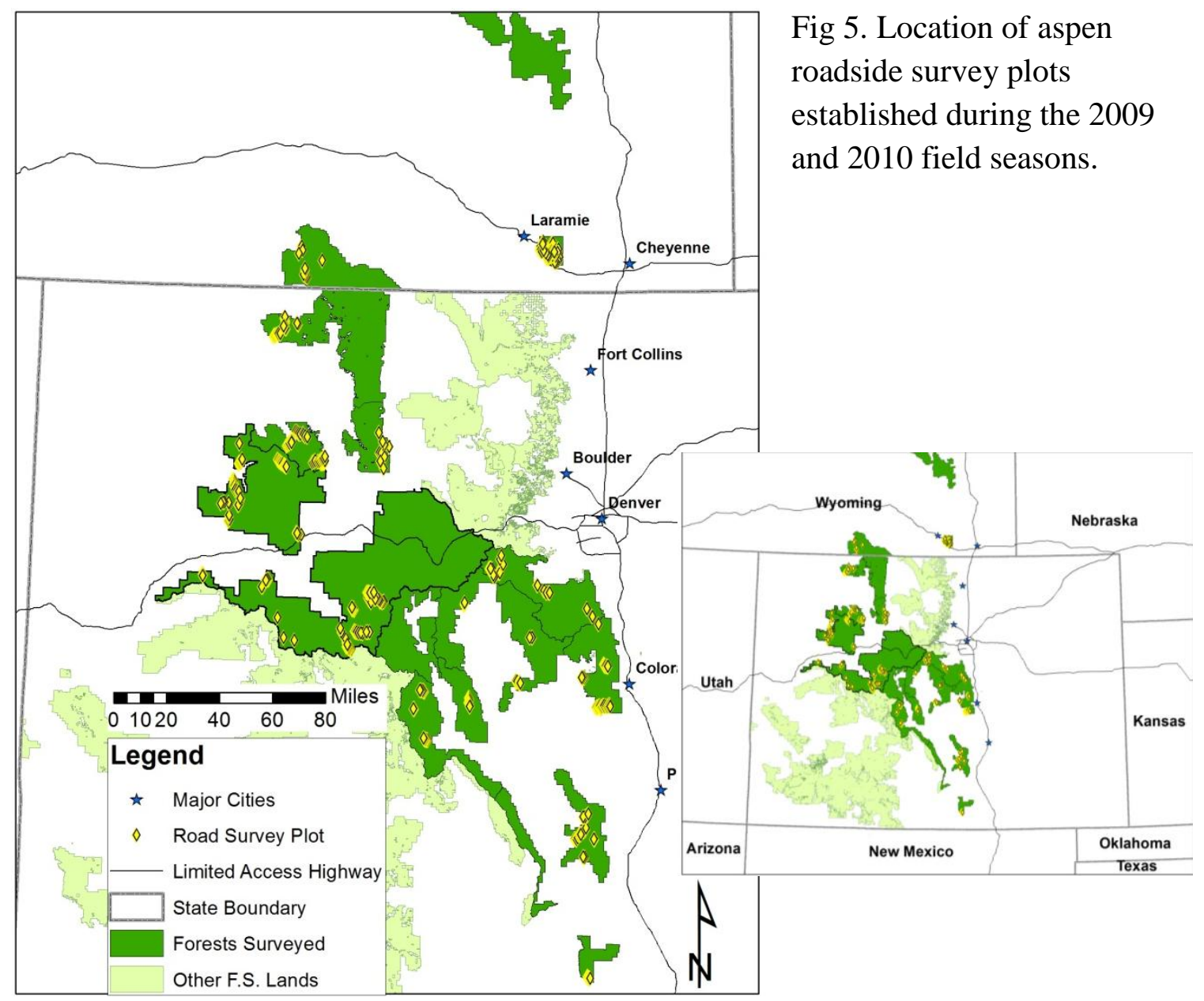




\section{Literature Cited}

Bagga, D.K., Smalley, E.B., 1969. Factors affecting development on Populus tremuloides artificially inoculated with Hypoxylon pruinatum. Can. J. Bot. 47, 907-914.

Baranyay, J.A., Hiratsuka, Y., 1967. Identification and distribution of Ciborinia whetzelii (Seaver) in western Canada. Can. J. Bot. 45, 189-191.

Barnes, B.V., 1966. The clonal growth habit of American aspens. Ecol. 47, 439-447.

Barnes, B.V., 1975. Phenotypic variation of trembling aspen in western North America. For. Sci. 21, 319-328.

Barter, G.W., 1965. Survival and development of the Bronze Poplar Borer Agrilus liragus Barter \& Brown (Coleoptera: Buprestidae). Can. Ent. 97, 1063-1068.

Bartos, D.L., 2008. Great Basin Aspen Ecosystems. In: Chambers, J.C., Devoe, N., Evenden, A. (Eds.), Collaborative Management and Research in the Great Basin: Examining the Issues and Developing a Framework for Action, General Technical Report RM-204. Rocky Mountain Research Station U.S.D.A. Forest Service, Fort Collins, CO.

Basham, J.T., 1958. Decay of trembling aspen. Can. J. Bot. 36, 491-505.

Beaty, R., Taylor, A., 2008. Fire history and the structure and dynamics of mixed conifer forest landscape in the northern Sierra Nevada, Lake Tahoe Basin, California, USA. For. Ecol. Manage. 255, $707-719$.

Beckwith, R.C., 1973. The large aspen tortrix. For. Pest. Leafl. 139. U.S.D.A. For. Serv., Washington, D.C. 5p.

Blodgett, J.T., Allen, K.K., Burns, K.S., 2007. Aspen mortality in the Rocky Mountain Region: extent, severity, and causal factors, INT-EM-07-01. U.S.D.A. Forest Service Forest Health Management, Rapid City, SD.

Bloomberg, W.J., 1962a. Cytospora canker on poplars: factors influencing the development of the disease. Can. J. Bot.40, 1271-1280.

Bloomberg, W.J., 1962b. Cytospora canker on poplars: the moisture relations and anatomy of the host. Can. J. Bot. 40, 1281-1292.

Brandt, J.P., Cerezke, H.F., Mallett, K.I., Volney, W.J.A., Weber, J.D., 2003. Factors affecting trembling aspen (Populus tremuloides Michx.) health in the boreal forest of Alberta, Saskatchewan, and Manitoba, Canada. For. Ecol. Man. 178, 287-300.

Broberg, C.L., Borden, J.H., 2005. Host preference by Saperda calcarata Say (Coleoptera: Cerambycidae). J. Entomol. Soc. Brit. Columbia. 102, 27-34. 
Brown, K.R., 1991. Carbon dioxide enrichment accelerates the decline in nutrient status and relative growth rate of Populus tremuloides Michx. Seedlings. Tree Phys. 8, 161-173.

Burks, S., 1994. Expression of Cytospora and Thyronectria cankers in response to host nutrition. Thesis. Colorado State University, Fort Collins, CO. 22 - 45.

Daubenmire, R., 1953. Nutrient content of leaf litter of trees in the Northern Rocky Mountains. Ecol. 34, 786 - 793.

Davidson, A.G., Prentice, R.M., 1968. Insects and diseases, in: Maini, J.S., Cayford, J.H.(Eds.), Growth and utilization of poplars in Canada. Dept For. Rural Dev. Publ. 1205. Ottawa, ON. 257p.

Diskin, M., Rocca, M.E., Nelson, K. N., Aoki, C.F., Romme, W.H., 2011. Forest developmental trajectories in mountain pine beetle disturbed forests of Rocky Mountain National Park, Colorado. Can. J. For. Res. 41, 782-792.

Donaldson, J.R., Lindroth, R.L., 2007. Genetics, environment, and their interaction to determine efficacy of chemical defense in trembling aspen. Ecol. 88, 729-739.

Eliasson, L., 1971. Growth regulators in Populus tremula: 4. Apical dominance and suckering in young plants. Physiol. Plant. 25, 263-267.

Eliasson, L., 1972. Translocation of shoot-applied indolylacetic acid in roots of Populus tremula. Physiol. Plant. 27, 412-416.

Enebak, S. A., Li, B., Ostry, M.E., 1996. Seedling response of two trembling aspen (Populus tremuloides) families to infection by Hypoxylon mammatum. Eur. J. For. Path. $26,245-252$.

Etheridge, D.E., 1961. Factors affecting branch infection in aspen. Can. J. Bot. 39, 799816.

Fairweather, M. L., Geil, B. W., Manthel, M., 2008. Aspen decline on the Coconino National Forest. In: McWilliams, M.G. (Ed.). Proceedings of the $55^{\text {th }}$ Western International Forest Disease Work Conference. Sedona, AZ, October 15-19 2007. Oregon Department of Forestry, Salem, OR.

Fralish, J.S., Loucks, O.L., 1967. Prediction of aspen site index from correlation with site factors in Wisconsin. U. WI For. Res. Note. 132.

Furniss, R.L., Carolin, V.M., 1977. Western forest insects. Misc. Publ. 1339. U.S.D.A., Washington, D.C. 
Furniss, M.M., Johnson, J.B., 1987. List of Idaho Scolytidae (Coleoptera) and notes on new records. Gr. Bas. Nat. 47, 375-382.

Graham, S.A., Harrison, R.P., Jr., Westell, C.E., 1963. Aspens: Phoenix trees of the great lakes region. Univ Mich, Ann Arbor.

Grant, M.C., Mitton, J.B., 1979. Elevational gradients in adult sex ratios and sexual differentiation in vegetative growth rates of Populus tremuloides Michx. Evol. 33, 914918.

Greitner, C.S., Pell, E.J., Winner W.E., 1994. Analysis of aspen foliage exposed to multiple stresses: ozone, nitrogen deficiency and drought. New Phytol. 127, 579 - 589.

Griffin, D.H., Schaedle, M.J., Devit, Manion, P.D., 1991. Clonal variation of Populus tremuloides responses to diurnal drought stress. Tree Physiol. 8, 297 - 304. Groves, J.W., Bowerman, C.A., 1955. The species of Ciborinia on Populus. Can. J. Bot. $33,577-590$.

Guyon, J. C., Jacobi, W. R., McIntyre, G.A., 1996. Effects of environmental stress on the development of Cytospora canker of aspen. Plant Dis. 80, 1320-1326.

Hancock, J.E., Bradley, K.L., Giardina, C.P., Pregitzer, K.S., 2008. The influence of soil type and altered lignin biosynthesis on the growth and above and belowground biomass allocation of Populus tremuloides. Plant Soil. 308: 239-253.

Hanks, L.M. 1999. Influence of the larval host plant on reproductive strategies of cerambycid beetles. Ann. Rev. Entomol. 44, 483-505.

Hinds, T.E., Davidson, R.W., 1972a. Ceratocystis species associated with the aspen Ambrosia beetle. Mycol. 64, 405-409.

Hinds, T.E., 1972b. Ceratocystis canker of aspen. Phytopath. 62, 213-220.

Hinds, T.E., 1981. Cryptosphaeria canker and Libertella decay of aspen. Phytopath. 71, $1137-1145$.

Hinds, T.E., Wengert, E.M., 1977. Growth and decay losses in Colorado aspen. Forest Service Research Paper, RM-193. Rocky Mountain Research Station U.S.D.A. Forest Service, Fort Collins, CO. 10p.

Hinds, T.E., in Aspen: Ecology and Management in the Western United States. 1985. DeByle, N. V., Winokur, R.P., eds. U.S.D.A, Forest Service. General Technical Report RM-119. 87 - 106.

Hogg, E.H, Hart, M., Lieffers, V.J., 2002. White tree rings formed in trembling aspen saplings following experimental defoliation. Can. J. For. Res. 32, 1929-1934. 
Hogg, E.H., Brandt, J.P., Michaelian M., 2008. Impacts of a regional drought on the productivity, dieback, and biomass of western Canadian aspen forests. Can. J. For. Res. $38,1373-1384$.

Holeski, L.M., Vogelzang, A., Stanosz, G., Lindroth, R.L., 2009. Incidence of Venturia shoot blight in aspen (Populus tremuloides Michx.) varies with tree chemistry and genotype. Biochem. Syst. Ecol. 37, 139-145.

Howell, B., 2009. Methods for mapping aspen dieback and mortality and defoliation in aerial detection surveys. U.S.D.A. For. Serv. For. Health Manage. Unpublished.

Jones, J.R., in Aspen: Ecology and Management in the Western United States, 1985.

DeByle, N. V., Winokur, R.P., eds. U.S.D.A, For.Serv.. Gen. Tech. Rep. RM-119. 232p.

Jones, J.R. Unpublished data and notes. Rocky Mountain Research Station, Flagstaff, AZ.

Kaye, M.M., Stohlgren, T.J., Binkley, D., 2003. Aspen structure and variability in Rocky Mountain National Park, Colorado, USA. Land. Ecol. 18, 591-603.

Krishnan, P., Black, T.A., Grant, N.J., Barr, A.G., Hogg, E.H., Jassal, R.S., Morgenstern, K., 2006. Impact of changing soil moisture distribution on net ecosystem productivity of a boreal aspen forest during and following drought. Agric. For. Meteorol. 139, 208 - 223.

Kukor, J.J., Martin, M.M., 1986. The transformation of Saperda calcarata into a cellulose digester through the inclusion of fungal enzymes in its diet. Oecol. 71, 138-141.

Kuehnholz, S., Borden, J.H., Uzunovic A., 2001. Secondary ambrosia beetles in apparently healthy trees: adaptations, potential causes and suggested research. Integ. Pest Man. Rev. 6, 209-219.

Kulakowski, D., Veblen, T.T., Kurzel, B.P., 2006. Influences of infrequent fire, elevation and pre-fire vegetation on the persistence of quaking aspen (Populus tremuloides Michx.) in the Flat Tops area, Colorado, USA. J. Biogeo. 33, 1397-1413.

Kurzel, B.P., Veblen, T.T., Kulakowski, D., 2007. A typology of stand structure and dynamics of Quaking aspen in northwestern Colorado. For. Ecol. Manage. 252, 176 190.

Lavertu, D., Mauffette, Y., Bergeron, Y., 1994. Effects of stand age and litter removal on the regeneration of Populus tremuloides. J. Veg. Sci. 5: 561-568.

Little, E. L., 1971. Atlas of United States trees: Vol. 1. Conifers and important hardwoods. U.S.D.A. For. Serv. Misc. Publ. 1146. Washington, D.C. 9p. 
McGregor, M.D., 1967. Biology and natural enemies of an aspen leaf tier, Sciaphila duplex, in the Intermountain Region. J. Econ. Ent. 60, 1213-1216.

Minnich, R.A., Barbour, M.G., Burk, J.H., Sosa-Ramirez, J., 2000. Californian mixedconifer forests under unmanaged fire regimes in the Sierra San Pedro Martir, Baja California, Mexico. J. Biogeogr. 27, 105 - 129.

Mueggler, W.F., in in Aspen: Ecology and Management in the Western United States, 1985. DeByle, N. V., Winokur, R.P., eds. U.S. Department of Agriculture, For.Serv..

Gen. Tech. Rep. RM-119. 45 - 55.

Perala, D.A., 1995. Quaking aspen productivity recovers after repeated prescribed fire. Res. Pap. U.S.D.A. For. Serv. North Cent. For. Exp. Stn., St Paul, MN.

Petty, J.I., 1977. Bionomics of two aspen bark beetles, Trypophloeus populi and Procryphalus mucronatus (Coleoptera: Scolytidae). Gr. Bas. Nat. 37, 105-127.

Rehfeldt, G.E., Ferguson, D.E., Crookston, N.L., 2009. Aspen, climate and sudden decline in western USA. For. Ecol. and Manag. 258, 2353-2364.

Romme, W.H., Turner, M.G., Wallace, L.L., Walker, J.S., 1995. Aspen, Elk, and Fire in Northern Yellowstone Park. Ecol. 76, 2097-2106.

Ross, W., 1976a. Fungi associated with root diseases of aspen in Wyoming. Can. J. Bot. $54,734-744$.

Ross, W., 1976b. Relation of aspen root size to infection by Ganoderma applanatum. Can. J. Bot. 54, 745-751.

Sandberg, D., 1951. The regeneration of quaking aspen by root suckering. Thesis. University of Minnesota, St. Paul, Minnesota.

Scheier, G.A., Campbell, R.B., 1978. Aspen sucker regeneration following burning and clearcutting on two sites in the Rocky Mountains. For. Sci. 24, 303-308.

Siemens, J.A., and Zwiazek, J.J., 2003. Effects of water deficit stress and recovery on the root water relations of trembling aspen (Populus tremuloides) seedlings. Pl. Sci. 165, 113 -120 .

Sinclair, W.A., Lyon, Johnson, W.T., 2005. Diseases of Trees and Shrubs, second ed. Cornell University Press, NY. 507p.

Smith, E.A., Collette, S.B., Boynton, T.A., Lillrose, T., Stevens, M.R., Bekker, M.F., Eggett, D., St Clair, S.B., 2011. Tree Physiol. 31, 68 - 77. 
Smith, E.A., and Smith, F.W., 2005. Twenty-year change in aspen dominance in pure aspen and mixed aspen/conifer stands on the Uncompahgre Plateau, Colorado, USA. For. Ecol. Manage. 213, $338-348$.

Spiers, A.G., 1984. Comparative studies of host specificity and symptoms exhibited by poplars infected with Marssonina brunea, Marssonina castagnei, and Marssonina populi (Lib.) Magnus. Eur. J. For. Path. 14, 202-218.

Steed, B.E., and Kearns, H.S.J., 2010. Damage agents and condition of mature aspen stands in Montana and northern Idaho. No. Rep. 10-03. U.S.D.A. For. Serv. For. Health Manage. 26p.

Stehr, F.W., Cook, E.F., 1968. A revision of the genus Melacosoma Hubner in North America. (Lepidoptera: Lasiocampdae): Systematics, biology, immatures, and parasites. U.S. Natl. Mus. Bull. 276. Washington, D.C. 321p.

Stelzer, M.J., 1968. The great basin tent caterpillar in New Mexico: life history, parasites, diseases, and defoliation. U.S.D.A. For. Serv. Res. Pap. RM-39. Rocky Mtn. Res. Sta., Fort Collins, CO. 16p.

Stelzer, M.J., 1971. Western tent caterpillar. For. Pest Leafl. 119. U.S.D.A.. For. Serv., Washington, D.C. $5 \mathrm{p}$.

Stevens, M.T., Esser, S.M., 2009. Growth-defense tradeoffs differ by gender in dioecious trembling aspen (Populus tremuloides). Biochem. Syst. Ecol. 37, 567 - 573.

Suzuki, K., Suzuki, H., Binkley, D., Stohlgren, T.J., 1999. Aspen regeneration in the Colorado front range: differences at local and landscape scales. Landsc. Ecol. 14, 231237.

Winton, L. L., 1968. Plantlets from Aspen tissue cultures. Sci. 160, 1234-1235.

Wolken, J.M., Lieffers, V.J., Landhausser, S.M., Mulak, T., 2009. Spring frost and decay fungi are implicated in suppressing aspen re-growth following partial cleaning in juvenile stands. Ann. For. Sci. 66, 805-813.

Wolter, K. E., 1968. Root and shoot initiation in aspen callus cultures. Nat. 219, 509-510.

Worrall, J.J., Egeland, L., Eager, T., Mask, R.A., Johnson E.W., Kemp, P.A., Shepperd, W.D., 2008. Rapid mortality of Populus tremuloides in southwestern Colorado, USA.

For. Ecol. and Manag. 255, 686-696.

Worrall, J.J., Marchetti, S.B., Egeland, L., Mask, R.A., Eager, T.E., Howell, B., 2010. Effects and etiology of sudden aspen decline in southwestern Colorado, USA. For. Ecol. and Manag. 260, 638-648. 
Ziller, W.G., 1974. The tree rusts of western Canada. Can. For. Serv. Publ. 1329. Dept. Env., Victoria, B.C. 272p. 


\section{Appendix A.: Methods Details}

Tree core and cross-section preparation

Cores were glued to a slim, grooved, wooden mounting block using white glue. Cores were aligned in the mounting block grooves such that the vascular tissues were perpendicular to the mounting block (i.e., faced up and down). Cores were then secured in the block groove to dry using tape. Samples were left to dry for at least twelve hours before sanding. Once the glue had completely dried, the top half (i.e., the rounded top edge) of the core was sanded off, first using a belt sander with 80-grit sandpaper, and then finished using 220-grit sandpaper. Cores were then hand-sanded using 400-grit sandpaper to produce a smooth surface with the tree rings clearly visible.

Regeneration cross-sections (or cookies) were given two flat, parallel surfaces to insure that the cross-section surface was flat and level. Samples were first cut using either a band saw or a reticulating saw and a vice, and then sanded using a belt sander with 80 grit sandpaper. Sample surfaces were further refined using either a belt or orbital sander with 220-grit sandpaper. Finally, the 'reading' surface was hand-sanded using 400-grit sandpaper.

\section{Skeleton Plot Symbology and Construction}

Standard dendrochronological symbology was used to indicate century (three dots in a line) and half-century (two dots) rings. In addition, decades were marked with a short line, and annual rings were each marked with a single dot. Skeleton plots were drawn for each sample using 1-mm square engineering paper. Such plots are graphic representations of tree age and relative growth, where the x-axis is time (in years), and the $y$-axis is an 
inverse scale of relative growth. Each sample was examined for the narrowest annual ring, and this was added to the skeleton plot as a 10-mm long line. All other rings were compared to the narrowest band, and graphed appropriately.

Equations used in data analysis

$$
\text { Proportion Live }=\frac{\text { number live stems }}{\text { total stems }} \text {, per size class, per plot. }
$$

Equation 1. The equation used to calculate the proportion of live aspen stems, by size class and plot.

$$
\mathrm{QMD}=\sqrt{ }\left(\frac{B A * \text { Frequency }}{k * T p H a}\right)
$$

Equation 2. The equation used to calculate the quadratic mean diameter (QMD) per size class, per hectare. Where $\mathrm{k}=$ is a constant, 0.0000785 ; Frequency is the number of aspen per size class, per plot; $\mathrm{TpHa}$ is the number of aspen per size class, per hectare.

$$
B A=\left(\frac{D B H}{2}\right)^{2} * \pi
$$

Equation 3. The equation used to calculate basal area, where DBH is diameter (in $\mathrm{cm}$ ) at breast height (i.e., $1.37 \mathrm{~m}$ from the ground).

$$
\mathrm{TpHa}=\frac{\text { Frequency }(2-4)}{h a}
$$

Equation 4. The equation used to calculate number of aspen stems per size class per hectare, where frequency (2-4) is the number of trees in each of the size classes 2-4, per plot; ha is hectares per plot.

$$
\mathrm{SI}=4.5 f t+0.48274 *\left(\left(\text { Tree } h t * 3.23 \frac{f t}{m}\right)-4.5 f t\right) *\left(e^{-0.07719 * A g e}\right)^{\wedge}-
$$

\subsection{2}

Equation 5. The equation to calculate Site Index, where Tree ht is average adult tree height and Age is average adult tree age. 


\section{Appendix B.: Analysis of Disease and Insect Prevalence by Aspen Size Class}

Table B1. Percent incidence of Cytospora canker among four size classes of aspen in Aspen Stand Assessment Plots in Colorado, 2009 - 2010

\begin{tabular}{|c|c|c|c|c|c|c|c|c|}
\hline \multirow{3}{*}{ Parameter } & \multirow{2}{*}{\multicolumn{2}{|c|}{$\begin{array}{c}\text { Saplings } \\
\mathbf{n}=610\end{array}$}} & \multirow{2}{*}{\multicolumn{2}{|c|}{$\begin{array}{c}\text { Small Pole } \\
\mathrm{n}=521\end{array}$}} & \multirow{2}{*}{\multicolumn{2}{|c|}{$\begin{array}{c}\text { Large Pole } \\
\mathrm{n}=546\end{array}$}} & \multirow{2}{*}{\multicolumn{2}{|c|}{$\begin{array}{c}\text { Adults } \\
\mathrm{n}=2564\end{array}$}} \\
\hline & & & & & & & & \\
\hline & $\begin{array}{c}\text { LS } \\
\text { Mean }\end{array}$ & $\begin{array}{c}\text { Std. } \\
\text { Error }\end{array}$ & $\begin{array}{c}\text { LS } \\
\text { Mean }\end{array}$ & $\begin{array}{c}\text { Std. } \\
\text { Error }\end{array}$ & $\begin{array}{c}\text { LS } \\
\text { Mean }\end{array}$ & $\begin{array}{c}\text { Std. } \\
\text { Error }\end{array}$ & LS Mean & $\begin{array}{c}\text { Std. } \\
\text { Error }\end{array}$ \\
\hline \multicolumn{9}{|l|}{ Elevation } \\
\hline Low & 8 & 8.3 & 15 & 6.5 & 12 & 5.6 & $21 \mathrm{c}$ & 3.5 \\
\hline Moderate & 1 & 8.0 & 13 & 6.4 & 20 & 5.0 & $16 \mathrm{~b}$ & 3.2 \\
\hline High & 5 & 9.1 & 11 & 9.5 & 23 & 6.4 & $10 \mathrm{a}$ & 4.2 \\
\hline \multicolumn{9}{|l|}{ Aspect } \\
\hline North & 0 & 8.6 & $32 b$ & 8.7 & $14 \mathrm{a}$ & 6.5 & $11 \mathrm{a}$ & 3.7 \\
\hline East & 8 & 8.3 & $6 a$ & 7.6 & $18 \mathrm{a}$ & 6.1 & $13 a$ & 3.7 \\
\hline South & 7 & 7.7 & $12 \mathrm{a}$ & 5.8 & $10 \mathrm{a}$ & 5.5 & $21 b$ & 3.4 \\
\hline West & 4 & 8.3 & $3 a$ & 7.9 & $31 \mathrm{~b}$ & 6.1 & $17 \mathrm{~b}$ & 3.6 \\
\hline \multicolumn{9}{|l|}{ Stand Type } \\
\hline Damaged & 2 & 8.0 & 12 & 6.9 & 18 & 5.0 & $22 b$ & 3.3 \\
\hline Healthy & 8 & 8.0 & 14 & 6.2 & 19 & 4.8 & $9 a$ & 3.4 \\
\hline \multicolumn{9}{|l|}{ Divide Position } \\
\hline East & 0 & 15.0 & 7 & 11.0 & 26 & 7.3 & $22 b$ & 3.5 \\
\hline West & 16 & 3.1 & 19 & 4.9 & 11 & 4.3 & $10 \mathrm{a}$ & 3.4 \\
\hline \multicolumn{9}{|l|}{ Forest (Divide) } \\
\hline Medicine Bow & $8 \mathrm{a}$ & 6.3 & 13 & 7.3 & 28 & 6.3 & $8 a$ & 4.0 \\
\hline Pike-San Isabel & $0 \mathrm{ab}$ & 29.0 & 0 & 19.8 & 25 & 13.9 & $36 \mathrm{~b}$ & 4.5 \\
\hline Routt & $22 b$ & 4.2 & 22 & 6.2 & 11 & 5.8 & $13 a$ & 3.8 \\
\hline White River & $10 \mathrm{a}$ & 3.5 & 17 & 5.0 & 10 & 4.1 & $7 a$ & 3.6 \\
\hline \multicolumn{9}{|l|}{ Slope Position } \\
\hline Summit - Shoulder & 4 & 7.5 & 9 & 6.3 & 18 & 4.0 & $11 \mathrm{a}$ & 3.1 \\
\hline $\begin{array}{l}\text { Backslope - } \\
\text { Footslope } \\
\end{array}$ & 9 & 9.4 & 11 & 10.6 & 14 & 8.9 & $23 b$ & 5.0 \\
\hline Toeslope - Valley & 1 & 8.3 & 20 & 7.9 & 24 & 6.4 & $13 \mathrm{~b}$ & 3.6 \\
\hline \multicolumn{9}{|l|}{$\%$ Slope } \\
\hline $0-9 \%$ & $0 \mathrm{a}$ & 8.1 & 11 & 6.3 & 12 & 6.1 & $29 \mathrm{c}$ & 3.6 \\
\hline $10-19 \%$ & $0 \mathrm{a}$ & 8.0 & 13 & 6.4 & 26 & 5.0 & $19 \mathrm{~b}$ & 3.4 \\
\hline $20-29 \%$ & $0 \mathrm{a}$ & 9.0 & 15 & 8.5 & 15 & 6.4 & $16 \mathrm{~b}$ & 3.8 \\
\hline $30-39 \%$ & $23 b$ & 8.7 & 23 & 8.2 & 21 & 6.7 & $10 \mathrm{a}$ & 4.0 \\
\hline$\geq 40 \%$ & $7 a$ & 9.5 & 2 & 8.4 & 17 & 6.5 & $4 \mathrm{a}$ & 4.1 \\
\hline \multicolumn{9}{|l|}{ Slope Configuration } \\
\hline Concave & 13 & 8.2 & 13 & 7.2 & $21 \mathrm{ab}$ & 6.0 & $30 \mathrm{~d}$ & 2.4 \\
\hline Convex & 16 & 7.8 & 10 & 6.3 & $15 \mathrm{a}$ & 5.1 & $21 \mathrm{bc}$ & 2.0 \\
\hline Linear & 4 & 8.5 & 6 & 8.0 & $27 \mathrm{~b}$ & 5.4 & $7 a$ & 2.6 \\
\hline Broken & & & & & & & $0 \mathrm{ac}$ & 14.7 \\
\hline Undulating & 2 & 8.5 & 23 & 7.2 & $11 \mathrm{a}$ & 6.1 & $24 a$ & 2.4 \\
\hline
\end{tabular}

Least-squares means are the average percentage of infested stems among four size classes of aspen, as modeled with the eight site and location parameters.

Significant differences between means are indicated by letters; means with different letters are significantly different from each other at the $\mathrm{P} \leq 0.05$ level.

Saplings were stems $0.3-1.37 \mathrm{~m}$ tall; small poles were those with DBH $0.1-2.9 \mathrm{~cm}$; large poles were those with DBH $3.0-11.9 \mathrm{~cm}$; adults were those with $\mathrm{DBH}>11.9 \mathrm{~cm}$. 
Table B2. Percent incidence of Black canker (Ceratocystis fimbriata) among two size classes of aspen in Aspen Stand Assessment Plots in

Colorado, 2009-2010

\begin{tabular}{|c|c|c|c|c|}
\hline \multirow[b]{2}{*}{ Parameter } & \multicolumn{2}{|c|}{$\begin{array}{c}\text { Large Pole } \\
n=546\end{array}$} & \multicolumn{2}{|c|}{$\begin{array}{c}\text { Adults } \\
n=2564\end{array}$} \\
\hline & LS Mean & $\begin{array}{l}\text { Std. } \\
\text { Error }\end{array}$ & LS Mean & $\begin{array}{l}\text { Std. } \\
\text { Error }\end{array}$ \\
\hline \multicolumn{5}{|l|}{ Elevation } \\
\hline Low & 0 & 1.5 & $1 \mathrm{a}$ & 1.5 \\
\hline Moderate & 2 & 1.3 & $3 b$ & 1.4 \\
\hline High & 2 & 1.7 & $3 a b$ & 1.8 \\
\hline \multicolumn{5}{|l|}{ Aspect } \\
\hline North & 0 & 1.7 & $2 \mathrm{a}$ & 1.6 \\
\hline East & 1 & 1.6 & $1 \mathrm{a}$ & 1.6 \\
\hline South & 1 & 1.5 & $1 \mathrm{a}$ & 1.4 \\
\hline West & 3 & 1.6 & $5 b$ & 1.5 \\
\hline \multicolumn{5}{|l|}{ Stand Type } \\
\hline Damaged & 2 & 1.3 & $3 b$ & 1.4 \\
\hline Healthy & 1 & 1.3 & $1 \mathrm{a}$ & 1.5 \\
\hline \multicolumn{5}{|l|}{ Divide Position } \\
\hline East & 1 & 1.9 & $4 b$ & 1.5 \\
\hline West & 1 & 1.1 & $1 \mathrm{a}$ & 1.5 \\
\hline
\end{tabular}

Forest (Divide)

\begin{tabular}{|l|r|r|r|r|}
\hline Medicine Bow & 2 & 1.7 & 3 & 1.7 \\
\hline Pike-San Isabel & 0 & 3.7 & 4 & 1.9 \\
\hline Routt & 1 & 1.5 & 1 & 1.6 \\
\hline White River & 1 & 1.1 & 1 & 1.5 \\
\hline
\end{tabular}

\section{Slope Position}

\begin{tabular}{|l|r|r|r|r|}
\hline Summit - Shoulder & 1 & 1.1 & $2 \mathrm{~b}$ & 1.3 \\
\hline Backslope - & & & & \\
Footslope & 0 & 2.4 & $0 \mathrm{a}$ & 2.0 \\
\hline Toeslope - Valley & 2 & 1.7 & $7 \mathrm{c}$ & 1.6 \\
\hline
\end{tabular}

Toeslope - Valley

$\%$ Slope

\begin{tabular}{|l|r|r|r|r|}
\hline $0-9 \%$ & 0 & 1.6 & $0 \mathrm{a}$ & 1.6 \\
\hline $10-19 \%$ & 1 & 1.3 & $2 \mathrm{~b}$ & 1.4 \\
\hline $20-29 \%$ & 3 & 1.7 & $2 \mathrm{ab}$ & 1.6 \\
\hline $30-39 \%$ & 1 & 1.8 & $4 \mathrm{~b}$ & 1.7 \\
\hline$\geq 40 \%$ & 1 & 1.7 & $2 \mathrm{ab}$ & 1.8 \\
\hline
\end{tabular}

Slope Configuration

\begin{tabular}{|l|r|r|r|r|}
\hline Concave & 2 & 1.6 & 4 & 1.0 \\
\hline Convex & 2 & 1.3 & 4 & 1.0 \\
\hline Linear & 0 & 1.4 & 2 & 1.1 \\
\hline Broken &. &. & 0 & 6.3 \\
\hline Undulating & 1 & 1.6 & 4 & 1.0 \\
\hline
\end{tabular}

Least-squares means are the average percentage of infested stems among four size classes of aspen, as modeled with the eight site and location parameters.

Significant differences between means are indicated by letters; means with different letters are significantly different from each other at the $\mathrm{P} \leq 0.05$ level.

Saplings were stems $0.3-1.37 \mathrm{~m}$ tall; small poles were those with DBH $0.1-2.9 \mathrm{~cm}$; large poles were those with DBH $3.0-11.9$ $\mathrm{cm}$; adults were those with DBH $>11.9 \mathrm{~cm}$. 
Table B3. Percent incidence of Sooty Bark canker (Encoelia pruinosa) among two size classes of aspen in Aspen Stand Assessment Plots in Colorado, 2009 - 2010

\begin{tabular}{|c|c|c|c|c|}
\hline & \multirow{3}{*}{\multicolumn{2}{|c|}{$\begin{array}{c}\text { Large Pole } \\
n=546\end{array}$}} & \multirow{3}{*}{\multicolumn{2}{|c|}{$\begin{array}{c}\text { Adults } \\
\mathrm{n}=\mathbf{2 5 6 4}\end{array}$}} \\
\hline & & & & \\
\hline & & & & \\
\hline Parameter & LS Mean & Std. Error & LS Mean & Std. Error \\
\hline \multicolumn{5}{|l|}{ Elevation } \\
\hline Low & 5 & 2.8 & 3 & 1.8 \\
\hline Moderate & 2 & 2.4 & 2 & 1.6 \\
\hline High & 0 & 3.0 & 2 & 2.1 \\
\hline \multicolumn{5}{|l|}{ Aspect } \\
\hline North & 2 & 3.2 & $1 \mathrm{a}$ & 1.9 \\
\hline East & 2 & 3.0 & $4 \mathrm{~b}$ & 1.8 \\
\hline South & 1 & 2.7 & $1 \mathrm{a}$ & 1.7 \\
\hline West & 2 & 3.0 & $3 a$ & 1.8 \\
\hline \multicolumn{5}{|l|}{ Stand Type } \\
\hline Damaged & 2 & 2.5 & $4 \mathrm{~b}$ & 1.6 \\
\hline Healthy & 1 & 2.4 & $0 \mathrm{a}$ & 1.7 \\
\hline \multicolumn{5}{|l|}{ Divide Position } \\
\hline East & 0 & 3.6 & 2 & 1.8 \\
\hline West & 3 & 2.1 & 2 & 1.7 \\
\hline \multicolumn{5}{|l|}{ Forest (Divide) } \\
\hline Medicine Bow & 0 & 3.1 & 4 & 2.0 \\
\hline Pike-San Isabel & 1 & 6.8 & 0 & 2.2 \\
\hline Routt & 2 & 2.8 & 3 & 1.9 \\
\hline White River & 4 & 2.0 & 2 & 1.8 \\
\hline \multicolumn{5}{|l|}{ Slope Position } \\
\hline $\begin{array}{l}\text { Summit - } \\
\text { Shoulder }\end{array}$ & 2 & 2.0 & $4 \mathrm{ab}$ & 1.5 \\
\hline $\begin{array}{l}\text { Backslope - } \\
\text { Footslope }\end{array}$ & 5 & 4.4 & $2 \mathrm{~b}$ & 2.3 \\
\hline Toeslope - Valley & 0 & 3.1 & $1 \mathrm{a}$ & 1.8 \\
\hline \multicolumn{5}{|l|}{ \% Slope } \\
\hline $0-9 \%$ & 3 & 3.0 & 3 & 1.8 \\
\hline $10-19 \%$ & 2 & 2.5 & 1 & 1.7 \\
\hline $20-29 \%$ & 0 & 3.1 & 2 & 1.9 \\
\hline $30-39 \%$ & 1 & 3.3 & 4 & 2.0 \\
\hline$\geq 40 \%$ & 3 & 3.2 & 1 & 2.0 \\
\hline \multicolumn{5}{|l|}{ Slope Configuration } \\
\hline Concave & 4 & 2.9 & 3 & 1.2 \\
\hline Convex & 2 & 2.5 & 1 & 1.0 \\
\hline Linear & 2 & 2.6 & 2 & 1.3 \\
\hline Broken & . & . & 2 & 7.3 \\
\hline Undulating & 0 & 3.0 & 3 & 1.2 \\
\hline
\end{tabular}

Least-squares means are the average percentage of infested stems among four size classes of aspen, as modeled with the eight site and location parameters.

Significant differences between means are indicated by letters; means with different letters are significantly different from each other at the $\mathrm{P} \leq 0.05$ level.

Large poles were those with DBH $3.0-11.9 \mathrm{~cm}$; adults were those with $\mathrm{DBH}>11.9 \mathrm{~cm}$. 
Table B4. Percent incidence of Phellinus decay (Phellinus tremula) among two size classes of aspen in Aspen Stand

Assessment Plots in Colorado, 2009-2010

\begin{tabular}{|c|c|c|c|c|}
\hline \multirow{4}{*}{ Parameter } & \multirow{2}{*}{\multicolumn{2}{|c|}{$\begin{array}{c}\text { Large Pole } \\
n=546\end{array}$}} & \multirow{2}{*}{\multicolumn{2}{|c|}{$\begin{array}{c}\text { Adults } \\
\mathrm{n}=2564\end{array}$}} \\
\hline & & & & \\
\hline & LS Mean & Std. Error & LS Mean & Std. Error \\
\hline & \multicolumn{4}{|c|}{ Elevation } \\
\hline Low & 1 & 1.5 & $4 a b$ & 2.0 \\
\hline Moderate & 1 & 1.3 & $5 b$ & 2.0 \\
\hline High & 0 & 1.7 & $3 a$ & 3.0 \\
\hline \multicolumn{5}{|l|}{ Aspect } \\
\hline North & 0 & 1.7 & $5 b$ & 2.6 \\
\hline East & 0 & 1.6 & $3 a b$ & 2.5 \\
\hline South & 0 & 1.5 & $0 \mathrm{a}$ & 2.3 \\
\hline West & 1 & 1.6 & $5 b$ & 2.5 \\
\hline \multicolumn{5}{|l|}{ Stand Type } \\
\hline Damaged & 1 & 1.3 & $4 \mathrm{~b}$ & 2.3 \\
\hline Healthy & 0 & 1.3 & $2 a$ & 2.4 \\
\hline \multicolumn{5}{|l|}{ Divide Position } \\
\hline East & 0 & 1.9 & $0 \mathrm{a}$ & 2.4 \\
\hline West & 0 & 1.1 & $6 \mathrm{~b}$ & 2.4 \\
\hline \multicolumn{5}{|l|}{ Forest (Divide) } \\
\hline Medicine Bow & 0 & 1.7 & 0 & 2.7 \\
\hline Pike-San Isabel & 1 & 3.7 & 3 & 3.1 \\
\hline Routt & 0 & 1.5 & 7 & 2.6 \\
\hline White River & 1 & 1.0 & 5 & 2.5 \\
\hline \multicolumn{5}{|l|}{ Slope Position } \\
\hline $\begin{array}{l}\text { Summit - } \\
\text { Shoulder }\end{array}$ & 0 & 2.4 & 2 & 3.1 \\
\hline $\begin{array}{l}\text { Backslope - } \\
\text { Footslope }\end{array}$ & 1 & 1.1 & 5 & 2.1 \\
\hline Toeslope - Valley & 0 & 1.7 & 2 & 2.5 \\
\hline \multicolumn{5}{|l|}{ \% Slope } \\
\hline $0-9 \%$ & 0 & 1.6 & 6 & 2.5 \\
\hline $10-19 \%$ & 0 & 1.3 & 5 & 2.3 \\
\hline $20-29 \%$ & 0 & 1.7 & 3 & 2.6 \\
\hline $30-39 \%$ & 0 & 1.8 & 1 & 2.7 \\
\hline$\geq 40 \%$ & 2 & 1.7 & 1 & 2.8 \\
\hline \multicolumn{5}{|l|}{ Slope Configuration } \\
\hline Concave & 2 & 1.6 & $6 \mathrm{~b}$ & 1.7 \\
\hline Convex & 0 & 1.3 & $3 a$ & 1.3 \\
\hline Linear & 0 & 1.4 & $3 a b$ & 1.8 \\
\hline Broken & & . & $0 \mathrm{ab}$ & 10.1 \\
\hline Undulating & 0 & 1.6 & $6 \mathrm{~b}$ & 1.6 \\
\hline
\end{tabular}

Least-squares means are the average percentage of infested stems among four size classes of aspen, as modeled with the eight site and location parameters.

Significant differences between means are indicated by letters; means with different letters are significantly different from each other at the $\mathrm{P} \leq 0.05$ level.

Large poles were those with DBH $3.0-11.9 \mathrm{~cm}$; adults were those with DBH $>11.9 \mathrm{~cm}$. 
Table B5. Percent incidence of Shepherd's crook blight (Venturia tremulae) among three size classes of aspen in Aspen Stand Assessment Plots in Colorado, 2009-2010

\begin{tabular}{|c|c|c|c|c|c|c|}
\hline \multirow[b]{2}{*}{ Parameter } & \multicolumn{2}{|c|}{$\begin{array}{c}\text { Saplings } \\
\mathrm{n}=610\end{array}$} & \multicolumn{2}{|c|}{$\begin{array}{c}\text { Small Pole } \\
n=521\end{array}$} & \multicolumn{2}{|c|}{$\begin{array}{c}\text { Large Pole } \\
\mathrm{n}=546\end{array}$} \\
\hline & $\begin{array}{c}\text { LS } \\
\text { Mean }\end{array}$ & $\begin{array}{c}\text { Std. } \\
\text { Error }\end{array}$ & $\begin{array}{c}\text { LS } \\
\text { Mean }\end{array}$ & $\begin{array}{c}\text { Std. } \\
\text { Error }\end{array}$ & $\begin{array}{c}\text { LS } \\
\text { Mean }\end{array}$ & $\begin{array}{c}\text { Std. } \\
\text { Error }\end{array}$ \\
\hline \multicolumn{7}{|l|}{ Elevation } \\
\hline Low & $10 \mathrm{~b}$ & 5.9 & $17 \mathrm{~b}$ & 4.6 & 1 & 0.7 \\
\hline Moderate & $0 \mathrm{a}$ & 5.5 & $10 \mathrm{~b}$ & 4.5 & 1 & 0.7 \\
\hline High & $10 \mathrm{~b}$ & 6.3 & $0 \mathrm{a}$ & 6.6 & 0 & 0.8 \\
\hline \multicolumn{7}{|l|}{ Aspect } \\
\hline North & $13 \mathrm{~b}$ & 5.9 & $15 \mathrm{~b}$ & 6.1 & 0 & 0.8 \\
\hline East & $3 \mathrm{a}$ & 5.7 & $9 \mathrm{ab}$ & 5.4 & 0 & 0.8 \\
\hline South & $4 a$ & 5.3 & $4 \mathrm{a}$ & 4.0 & 0 & 0.7 \\
\hline West & $3 a$ & 5.7 & $7 a b$ & 5.5 & 0 & 0.8 \\
\hline \multicolumn{7}{|l|}{ Stand Type } \\
\hline Damaged & $3 \mathrm{a}$ & 5.5 & $5 \mathrm{a}$ & 49.0 & 0 & 0.7 \\
\hline Healthy & $8 \mathrm{~b}$ & 5.3 & $12 b$ & 4.4 & 1 & 0.6 \\
\hline \multicolumn{7}{|l|}{ Divide Position } \\
\hline East & 0 & 10.2 & 7 & 7.6 & 1 & 1.0 \\
\hline West & 13 & 2.1 & 10 & 3.4 & 0 & 0.6 \\
\hline \multicolumn{7}{|l|}{ Forest (Divide) } \\
\hline Medicine Bow & 6 & 4.3 & 4 & 5.1 & 0 & 0.8 \\
\hline Pike-San Isabel & 0 & 20.2 & 11 & 13.8 & 2 & 1.8 \\
\hline Routt & 11 & 2.9 & 7 & 4.4 & 0 & 0.8 \\
\hline White River & 14 & 2.4 & 13 & 3.5 & 0 & 0.5 \\
\hline \multicolumn{7}{|l|}{ Slope Position } \\
\hline $\begin{array}{l}\text { Summit - } \\
\text { Shoulder }\end{array}$ & 6 & 6.5 & 4 & 7.4 & 0 & 1.2 \\
\hline $\begin{array}{l}\text { Backslope - } \\
\text { Footslope }\end{array}$ & 5 & 5.2 & 7 & 4.4 & 1 & 0.5 \\
\hline Toeslope - Valley & 6 & 5.7 & 14 & 5.5 & 1 & 0.8 \\
\hline \multicolumn{7}{|l|}{ \% Slope } \\
\hline $0-9 \%$ & $0 \mathrm{a}$ & 5.6 & $0 \mathrm{a}$ & 4.4 & $0 \mathrm{a}$ & 0.8 \\
\hline $10-19 \%$ & $1 \mathrm{a}$ & 5.5 & $8 \mathrm{~b}$ & 4.5 & $0 \mathrm{a}$ & 0.7 \\
\hline $20-29 \%$ & $12 b$ & 6.2 & $12 \mathrm{bc}$ & 6.0 & $0 \mathrm{a}$ & 0.8 \\
\hline $30-39 \%$ & $3 a$ & 5.9 & $7 \mathrm{ab}$ & 5.7 & $0 \mathrm{a}$ & 0.9 \\
\hline$\geq 40 \%$ & $13 b$ & 6.6 & $18 \mathrm{c}$ & 5.9 & $2 \mathrm{~b}$ & 0.8 \\
\hline \multicolumn{7}{|l|}{ Slope Configuration } \\
\hline Concave & $5 a$ & 5.6 & 11 & 5.1 & $0 \mathrm{ab}$ & 0.8 \\
\hline Convex & $12 b$ & 5.4 & 4 & 4.4 & $0 \mathrm{a}$ & 0.7 \\
\hline Linear & $1 \mathrm{a}$ & 5.8 & 8 & 5.6 & $0 \mathrm{ab}$ & 0.7 \\
\hline \multicolumn{7}{|l|}{ Broken } \\
\hline Undulating & $4 a$ & 5.8 & 12 & 5.1 & $1 \mathrm{~b}$ & 0.8 \\
\hline
\end{tabular}

Least-squares means are the average percentage of infested stems among four size classes of aspen, as modeled with the eight site and location parameters.

Significant differences between means are indicated by letters; means with different letters are significantly different from each other at the $\mathrm{P} \leq 0.05$ level.

Saplings were stems $0.3-1.37 \mathrm{~m}$ tall; small poles were those with DBH $0.1-2.9 \mathrm{~cm}$; large poles were those with DBH $3.0-11.9 \mathrm{~cm}$. 
Table B6. Percent incidence of Marssonina leaf blight (Marssonina populi) among three size classes of aspen in Aspen Stand Assessment Plots in Colorado, 2009-

2010

\begin{tabular}{|c|c|c|c|c|c|c|c|c|}
\hline \multirow{3}{*}{ Parameter } & \multirow{2}{*}{\multicolumn{2}{|c|}{$\begin{array}{c}\text { Saplings } \\
\mathrm{n}=610\end{array}$}} & \multirow{2}{*}{\multicolumn{2}{|c|}{$\begin{array}{c}\text { Small Pole } \\
\mathrm{n}=521\end{array}$}} & \multirow{2}{*}{\multicolumn{2}{|c|}{$\begin{array}{c}\text { Large Pole } \\
n=546 \\
\end{array}$}} & \multirow{2}{*}{\multicolumn{2}{|c|}{$\frac{\text { Adults }}{\mathrm{n}=\mathbf{2 5 6 4}}$}} \\
\hline & & & & & & & & \\
\hline & $\begin{array}{c}\text { LS } \\
\text { Mean }\end{array}$ & $\begin{array}{c}\text { Std. } \\
\text { Error }\end{array}$ & $\begin{array}{c}\text { LS } \\
\text { Mean }\end{array}$ & $\begin{array}{c}\text { Std. } \\
\text { Error }\end{array}$ & $\begin{array}{c}\text { LS } \\
\text { Mean }\end{array}$ & $\begin{array}{c}\text { Std. } \\
\text { Error }\end{array}$ & $\begin{array}{c}\text { LS } \\
\text { Mean }\end{array}$ & $\begin{array}{c}\text { Std. } \\
\text { Error }\end{array}$ \\
\hline \multicolumn{9}{|l|}{ Elevation } \\
\hline Low & $32 \mathrm{c}$ & 10.4 & 33 & 7.3 & $21 \mathrm{c}$ & 5.3 & 9 & 2.2 \\
\hline Moderate & $2 b$ & 10.1 & 23 & 7.2 & $4 \mathrm{~b}$ & 4.7 & 6 & 2.0 \\
\hline High & $0 \mathrm{a}$ & 11.5 & 15 & 10.6 & $0 \mathrm{a}$ & 6.1 & 3 & 2.6 \\
\hline \multicolumn{9}{|l|}{ Aspect } \\
\hline North & $26 c$ & 10.8 & $35 b$ & 9.7 & $2 \mathrm{a}$ & 6.1 & $7 b$ & 2.3 \\
\hline East & $0 \mathrm{a}$ & 10.5 & $10 \mathrm{a}$ & 8.6 & $0 \mathrm{a}$ & 5.7 & $6 b$ & 2.3 \\
\hline South & $17 \mathrm{c}$ & 9.7 & $11 \mathrm{a}$ & 6.5 & $13 \mathrm{~b}$ & 5.2 & $3 a$ & 2.1 \\
\hline West & $\mathrm{Ob}$ & 10.5 & $39 b$ & 8.8 & $7 \mathrm{a}$ & 5.8 & $8 \mathrm{~b}$ & 2.2 \\
\hline \multicolumn{9}{|l|}{ Stand Type } \\
\hline Damaged & 5 & 10.2 & 26 & 7.8 & 5 & 4.7 & 6 & 2.0 \\
\hline Healthy & 7 & 9.8 & 21 & 7.0 & 5 & 4.6 & 6 & 2.1 \\
\hline \multicolumn{9}{|l|}{ Divide Position } \\
\hline East & $0 \mathrm{a}$ & 18.8 & $2 \mathrm{a}$ & 12.2 & $0 \mathrm{a}$ & 6.9 & $2 a$ & 2.2 \\
\hline West & $40 b$ & 3.9 & $46 b$ & 5.5 & $17 \mathrm{~b}$ & 4.0 & $11 \mathrm{~b}$ & 2.1 \\
\hline \multicolumn{9}{|l|}{ Forest (Divide) } \\
\hline Medicine Bow & $0 \mathrm{a}$ & 8.0 & $0 \mathrm{a}$ & 8.1 & $0 \mathrm{a}$ & 6.0 & $0 \mathrm{a}$ & 2.4 \\
\hline Pike-San Isabel & $0 \mathrm{ab}$ & 37.1 & $5 b$ & 22.2 & $9 \mathrm{~b}$ & 13.2 & $3 a b$ & 2.8 \\
\hline Routt & $56 c$ & 5.3 & $55 \mathrm{c}$ & 7.0 & $28 \mathrm{~b}$ & 5.4 & $16 \mathrm{c}$ & 2.3 \\
\hline White River & $26 b$ & 4.5 & $37 \mathrm{~b}$ & 5.6 & $5 b$ & 3.9 & $5 b$ & 2.2 \\
\hline \multicolumn{9}{|l|}{ Slope Position } \\
\hline $\begin{array}{l}\text { Summit - } \\
\text { Shoulder }\end{array}$ & $20 b$ & 11.9 & $36 b$ & 11.9 & 2 & 8.4 & $0 \mathrm{a}$ & 2.8 \\
\hline $\begin{array}{l}\text { Backslope - } \\
\text { Footslope }\end{array}$ & $4 a$ & 9.5 & $26 \mathrm{~b}$ & 7.1 & 11 & 3.8 & $5 b$ & 1.9 \\
\hline Toeslope - Valley & $0 \mathrm{a}$ & 10.5 & $8 \mathrm{a}$ & 8.9 & 1 & 6.0 & $14 \mathrm{c}$ & 2.3 \\
\hline \multicolumn{9}{|l|}{$\%$ Slope } \\
\hline $0-9 \%$ & $36 c$ & 10.2 & $33 \mathrm{~cd}$ & 7.0 & $18 \mathrm{c}$ & 5.8 & $2 a$ & 2.2 \\
\hline $10-19 \%$ & $11 \mathrm{~b}$ & 10.1 & $30 \mathrm{c}$ & 7.2 & $9 \mathrm{bc}$ & 4.7 & $7 b$ & 2.1 \\
\hline $20-29 \%$ & $0 \mathrm{a}$ & 11.3 & $0 \mathrm{a}$ & & $0 \mathrm{a}$ & 6.0 & $1 \mathrm{a}$ & 2.3 \\
\hline $30-39 \%$ & $27 \mathrm{c}$ & 10.9 & $49 \mathrm{~d}$ & 9.2 & $2 b$ & 6.3 & $7 \mathrm{~b}$ & 2.4 \\
\hline$\geq 40 \%$ & $0 \mathrm{a}$ & 12.0 & $14 \mathrm{~b}$ & 9.4 & $4 \mathrm{~b}$ & 6.1 & $14 c$ & 2.5 \\
\hline \multicolumn{9}{|l|}{ Slope Configuration } \\
\hline Concave & $19 \mathrm{~b}$ & 10.4 & $38 \mathrm{c}$ & 8.1 & 12 & 5.7 & 4be & 1.5 \\
\hline Convex & $34 \mathrm{c}$ & 9.9 & $21 b$ & 7.0 & 6 & 4.8 & $9 \mathrm{~cd}$ & 1.2 \\
\hline Linear & $0 \mathrm{a}$ & 10.7 & $24 \mathrm{~b}$ & 9.0 & 4 & 5.1 & $7 \mathrm{~cd}$ & 1.6 \\
\hline Broken & & & & & . & & 9de & 9.1 \\
\hline Undulating & $0 \mathrm{a}$ & 10.7 & $10 \mathrm{ab}$ & 8.1 & 0 & 5.8 & 1ade & 1.5 \\
\hline
\end{tabular}

Least-squares means are the average percentage of infested stems among four size classes of aspen, as modeled with the eight site and location parameters.

Significant differences between means are indicated by letters; means with different letters are significantly different from each other at the $\mathrm{P} \leq 0.05$ level.

Saplings were stems $0.3-1.37 \mathrm{~m}$ tall; small poles were those with DBH $0.1-2.9 \mathrm{~cm}$; large poles were those with DBH $3.0-11.9 \mathrm{~cm}$; adults were those with $\mathrm{DBH}>11.9 \mathrm{~cm}$. 